\title{
HYDROGEOLOGIC FRAMEWORK OF THE PUGET SOUND AQUIFER SYSTEM, WASHINGTON AND BRITISH COLUMBIA
}

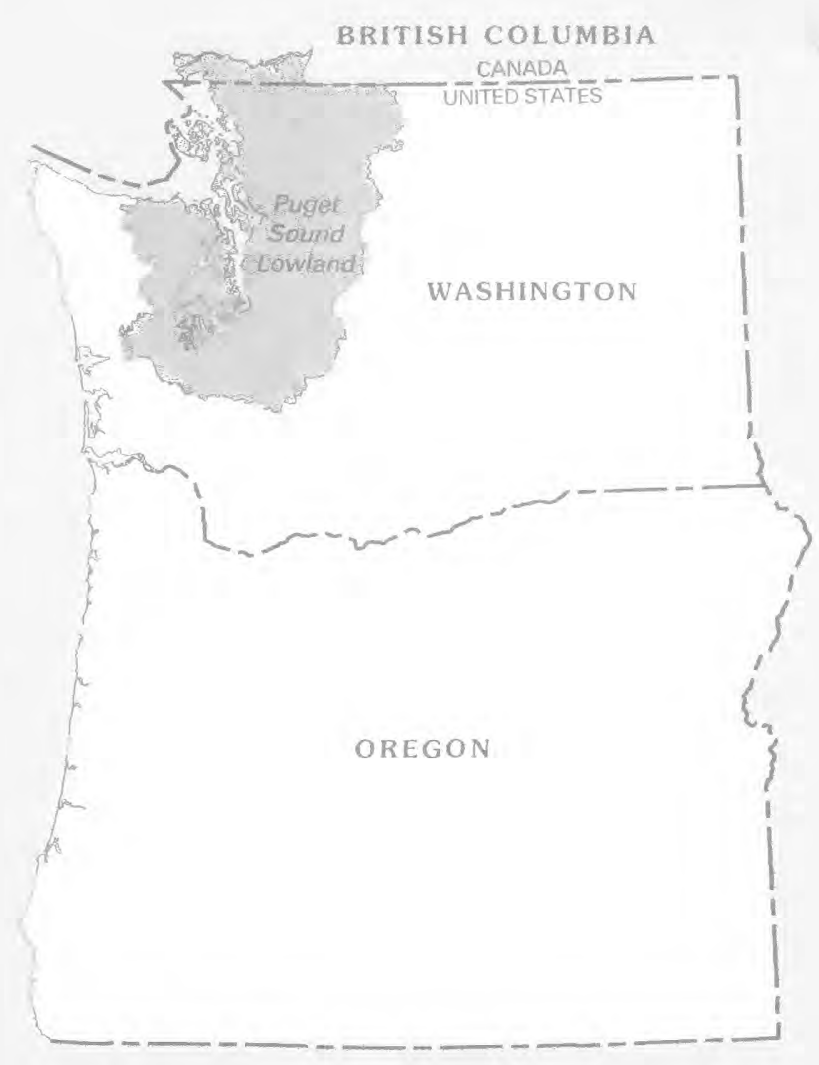




\section{AVAILABILITY OF BOOKS AND MAPS OF THE U.S. GEOLOGICAL SURVEY}

Instructions on ordering publications of the U.S. Geological Survey, along with prices of the last offerings, are given in the currentyear issues of the monthly catalog "New Publications of the U.S. Geological Survey." Prices of available U.S. Geological Survey publications released prior to the current year are listed in the most recent annual "Price and Availability List." Publications that may be listed in various U.S. Geological Survey catalogs (see back inside cover) but not listed in the most recent annual "Price and Availability List" may be no longer available.

Order U.S. Geological Survey publications by mail or over the counter from the offices given below.

\section{BY MAIL}

\section{Books}

Professional Papers, Bulletins, Water-Supply Papers, Techniques of Water-Resources Investigations, Circulars, publications of general interest (such as leaflets, pamphlets, booklets), single copies of Preliminary Determination of Epicenters, and some miscellaneous reports, including some of the foregoing series that have gone out of print at the Superintendent of Documents, are obtainable by mail from

\section{U.S. Geological Survey, Information Services Box 25286, Federal Center, Denver, CO 80225}

Subscriptions to Preliminary Determination of Epicenters can be obtained ONLY from the

\section{Superintendent of Documents Government Printing Office Washington, DC 20402} Documents.)

(Check or money order must be payable to Superintendent of

\section{Maps}

For maps, address mail orders to

U.S. Geological Survey, Information Services Box 25286, Federal Center, Denver, CO 80225

\section{OVER THE COUNTER}

\section{Books and Maps}

Books and maps of the U.S. Geological Survey are available over the counter at the following U.S. Geological Survey Earth Science Information Centers (ESIC's), all of which are authorized agents of the Superintendent of Documents:

- ANCHORAGE, Alaska - Rm. 101, 4230 University Dr.

- LAKEWOOD, Colorado-Federal Center, Bldg. 810

- MENLO PARK, California-Bldg. 3, Rm. 3128, 345 Middlefield Rd.

- RESTON, Virginia-USGS National Center, Rm. 1C402, 12201 Sunrise Valley Dr.

- SALT LAKE CITY, Utah-Federal Bldg., Rm. 8105, 125 South State St.

- SPOKANE, Washington-U.S. Post Office Bldg., Rm. 135, West 904 Riverside Ave.

- WASHINGTON, D.C.-Main Interior Bldg., Rm. 2650, 18th and C Sts., NW.

\section{Maps Only}

Maps may be purchased over the counter at the following U.S. Geological Survey office:

- ROLLA, Missouri-1400 Independence Rd. 
Hydrogeologic Framework of the Puget Sound Aquifer System, Washington and British Columbia

By J.J. Vaccaro, A.J. Hansen, Jr., and M.A. Jones

REGIONAL AQUIFER-SYSTEM ANALYSIS-

PUGET-WILLAMETTE LOWLAND

U.S. GEOLOGICAL SURVEY PROFESSIONAL PAPER 1424-D

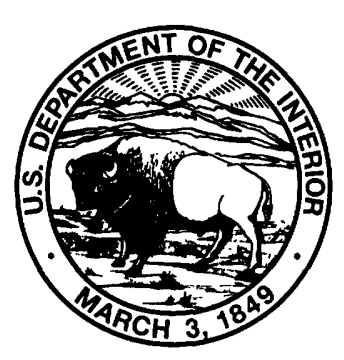




\title{
U.S. DEPARTMENT OF THE INTERIOR \\ BRUCE BABBITT, Secretary
}

\author{
U.S. GEOLOGICAL SURVEY
}

Mark Schaefer, Acting Director

The use of firm, trade, and brand names in this report is for identification purposes only and does not constitute endorsement by the U.S. Government.

\section{Library of Congress Cataloging in Publications Data \\ Vaccaro, J.J. \\ Hydrogeologic framework of the Puget Sound aquifer system, Washington and British Columbia / by J.J. Vaccaro, A.J. Hansen, Jr., and M.A. Jones.}

77 p. cm.-(Regional aquifer-system analysis-Puget-Willamette lowland ; D) (U.S. Geological Survey professional paper; 1424) Includes bibliographical references.

Supt. of Docs. no.: I 19.16:1424-D

1. Hydrogeology-Washington (State)-Puget Sound Region. 2. Hydrogeology-British Columbia. 3. Aquifers-Washington (State)-Puget Sound Region. 4. Aquifers-British Columbia. I. Hansen, Arnold J., 1932- . II. Jones, M. A. (Myrtle Anne), 1952- . III Title. IV. Series. V. Series: U.S. Geological Survey professional paper ; 1424.

GB1025.W2V33 1998

97-23883

551.49'09797'7-dc21

CIP

ISBN 0-607-87047-8

For sale by U.S. Geological Survey, Information Services Box 25286, Federal Center

Denver, CO 80225 


\section{FOREWORD}

\section{THE REGIONAL AQUIFER-SYSTEM ANALYSIS PROGRAM}

The RASA Program represents a systematic effort to study a number of the Nation's most important aquifer systems, which, in aggregate, underlie much of the country and which represent an important component of the Nation's total water supply. In general, the boundaries of these studies are identified by the hydrologic extent of each system and, accordingly, transcend the political subdivisions to which investigations have often arbitrarily been limited in the past. The broad objective for each study is to assemble geologic, hydrologic, and geochemical information, to analyze and develop an understanding of the system, and to develop predictive capabilities that will contribute to the effective management of the system. The use of computer simulation is an important element of the RASA studies to develop an understanding of the natural, undisturbed hydrologic system and the changes brought about in it by human activities and to provide a means of predicting the regional effects of future pumping or other stresses. The final interpretive results of the RASA Program are presented in a series of U.S. Geological Survey Professional Papers that describe the geology, hydrology, and geochemistry of each regional aquifer system. Each study within the RASA Program is assigned a single Professional Paper number beginning with Professional Paper 1400.

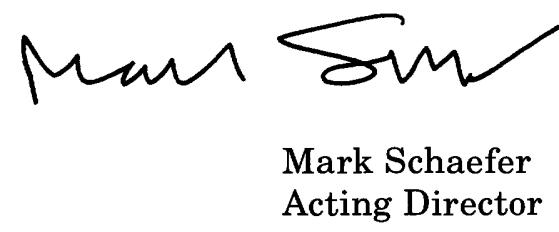





\section{CONTENTS}

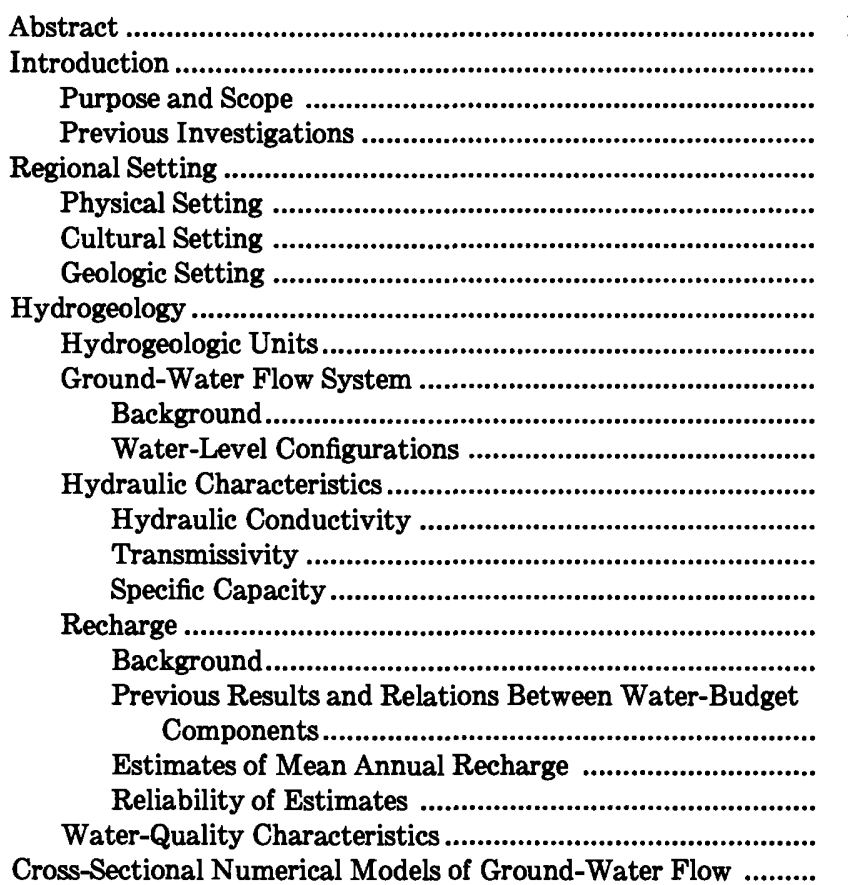

\begin{tabular}{|c|c|}
\hline Page & \\
\hline D1 & Model Grid Systems .......................... \\
\hline 1 & Boundary Conditions ................... \\
\hline 2 & Hydraulic Characteristics .............. \\
\hline 5 & Calculated Flow Systems ................ \\
\hline 7 & Hydrologic Controls ................ \\
\hline 7 & Hydraulic-Head Gradients ....... \\
\hline 9 & Ground-Water Flowpaths and Traveltimes .. \\
\hline 10 & Evaluation of the Flow Systems \\
\hline 17 & Calculated Water-Budget Components \\
\hline 17 & Total Ground-Water Flow \\
\hline 20 & Partitioning of Ground-Water Flow ................................ \\
\hline 21 & 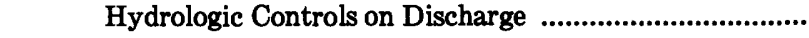 \\
\hline 22 & Discharge to Saltwater Bodies .... \\
\hline 26 & Vertical Movement of Water ........ \\
\hline 26 & Conceptual Model of the Aquifer System \\
\hline 30 & Description of Conceptual Model ......... \\
\hline 30 & Glacial-Interglacial Sequence ....................................... \\
\hline 30 & Surficial Semiconfining Unit . \\
\hline 31 & Confining Unit ............ \\
\hline & Fraser and Puget Aquifers \\
\hline 3 & vial Valley Aquifers ................................................. \\
\hline 37 & Recessional Deposits .......... \\
\hline 40 & Application of Conceptual Model . \\
\hline 4 & Summary and Conclusions .................. \\
\hline 45 & \\
\hline
\end{tabular}

\section{ILLUSTRATIONS}

PLATE 1. Cross-sectional model grid systems with boundary conditions and calculated hydraulic-head distributions for detailed and aggregated aquifer system geometry, Puget Sound aquifer system, Washington and British Columbia In pocket

FIGURES 1-2. Maps showing:

1. Location of the Puget Sound Lowland and the Willamette Lowland, which make up the Puget-Willamette Lowland regional aquifer-system study area

2. Location and features of the Puget Sound Lowland, Washington and British Columbia

3. Graphs showing climate characteristics for selected areas in the Puget Sound Lowland $-(A)$ water-year precipitation, (B) mean monthly distribution of precipitation, $(C)$ daily minimum and maximum air temperature, and $(D)$ daily mean solar and net radiation

4-5. Diagrams showing:

4. Generalized tectonic features

5. Framework for the regional correlation of hydrogeologic and stratigraphic units for the Puget Sound Lowland, (A) Fraser-Whatcom Basin, (B) north-central Puget Sound Lowland, and $(C)$ southern Puget Sound Lowland ...

6. Map showing generalized surficial geology of the Puget Sound Lowland and location of three major structural basins or subareas.

7. Diagram showing idealized sequence of unconsolidated deposits in the Puget Sound Lowland

8. Map showing generalized thickness of the unconsolidated deposits composing the Puget Sound aquifer system ..............

9. Graph showing linear relations between water-level altitude and land-surface altitude

10-11. Maps showing:

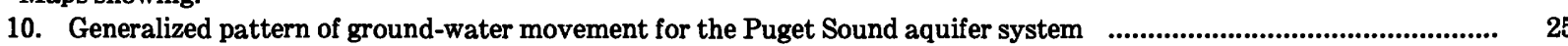

11. Location of 26 basins or areas where recharge was estimated by investigators using daily climate data and 7 basins where recharge, estimated during this study, is compared to streamflow 
FIGURES12. Graph showing relations between mean annual precipitation and recharge for 26 basins or areas

13. Map showing estimated distribution of mean annual ground-water recharge for the Puget Sound aquifer system $\quad . . . . . . . . . \quad 38$

14. Graph showing estimated distribution of annual recharge at two weather stations, representative of small-and largeprecipitation areas, for two different surficial geologic units

15. Map showing the lateral extents of the surficial regional hydrogeologic units

16. Relation between stratigraphic units and regional hydrogeologic units for the Puget Sound aquifer system, $(A)$ FraserWhatcom Basin, (B) north-central Puget Sound Lowland, and $(C)$ southern Puget Sound Lowland

17. Idealized section showing examples of extent and names of regional hydrogeologic units for $(A)$ section $E-E^{\prime}$ and $(B)$ section $F-F^{\prime}$

18. Diagrams showing geometry of aquifer and confining units and model grid system with boundary conditions for section $G-G$ ',Fraser-Whatcom Basin

19. Diagrams showing model-calculated hydraulic heads and estimated and observed water levels for section $G-G$ ', FraserWhatcom Basin

\section{TABLES}

TABLE 1. Availability of well information for the Puget Sound Lowland in the U.S. Geological Survey's National Water Information System as of 1990

2. Descriptive statistics for:

A. Well information

B. Well information and regression information ...

3. Summary of published estimates of horizontal hydraulic conductivity

4. Summary of published estimates of ground-water recharge calculated using daily climate data

5. Information and statistics on the relation between water-budget components

6. Estimates of mean annual recharge on the basis of mean annual precipitation, generalized surficial geology, and land-use and cover categories

7. Information for comparison of streamflow and estimated recharge for seven basins

8. Summary of historical ground-water-quality data

9. Relation between model layers and local hydrogeologic units and the potential relations between the hydrogeologic and stratigraphic units.

10. Information for the model grid systems for six cross-sectional ground-water flow models

11. Ranges in recharge estimates and hydraulic characteristics for six cross-sectional ground-water flow models

12. Model-calculated water-budget components for six cross-sectional ground-water flow models

13. Model-calculated percentage of recharge that moves downward from above the identified unit to underlying units and moves upward from below the identified unit to overlying units 


\section{CONVERSTION FACTORS AND VERTICAL DATUM}

\begin{tabular}{|c|c|c|}
\hline Multiply & By & To obtain \\
\hline inch (in.) & $\overline{2.54}$ & centimeter \\
\hline foot $(\mathrm{ft})$ & 0.3048 & meter \\
\hline mile (mi) & 1.609 & kilometer \\
\hline acre & 0.4047 & hectare \\
\hline square foot $\left(\mathrm{ft}^{2}\right)$ & 0.0929 & square meter \\
\hline square mile $\left(\mathrm{mi}^{2}\right)$ & 2.590 & square kilometer \\
\hline acre-foot (acre-ft) & $1,233.50$ & cubic meter \\
\hline cubic mile $\left(\mathrm{mi}^{3}\right)$ & 4.168 & cubic kilometer \\
\hline inch per year (in/yr) & 2.54 & centimeter per year \\
\hline foot per second $(\mathrm{ft} / \mathrm{s})$ & 0.3048 & meter per second \\
\hline foot per foot $(\mathrm{ft} / \mathrm{ft})$ & 1.0 & meter per meter \\
\hline foot per mile ( $\mathrm{ft} / \mathrm{mi})$ & 0.1894 & meter per kilometer \\
\hline foot per day $(\mathrm{ft} / \mathrm{d})$ & 0.3048 & meter per day \\
\hline foot squared per second $\left(\mathrm{ft}^{2} / \mathrm{s}\right)$ & 0.0929 & meter squared per second \\
\hline foot squared per day $\left(\mathrm{ft}^{2} / \mathrm{d}\right)$ & 0.0929 & meter squared per day \\
\hline cubic foot per second $\left(\mathrm{ft}^{3} / \mathrm{s}\right)$ & 0.02832 & cubic meter per second \\
\hline cubic foot per second per mile $\left[\left(\mathrm{ft}^{3} / \mathrm{s}\right) / \mathrm{mi}\right]$ & 0.0176 & cubic meter per second per kilometer \\
\hline cubic foot per second per square mile $\left[\left(\mathrm{ft}^{3} / \mathrm{s}\right) / \mathrm{mi}^{2}\right]$ & 0.01093 & cubic meter per second per square kilometer \\
\hline million gallons per day (Mgal/d) & 0.04381 & cubic meter per second \\
\hline gallon per minute (gal/min) & 0.06308 & liter per second \\
\hline gallon per minute per foot $[(\mathrm{gal} / \mathrm{min}] / \mathrm{ft}]$ & 0.2070 & liter per second per meter \\
\hline
\end{tabular}

\section{TEMPERATURE}

To correct temperature given in this report in degrees Fahrenheit $\left({ }^{\circ} \mathrm{F}\right)$ to degrees Celsius $\left({ }^{\circ} \mathrm{C}\right)$, use the following equation:

$$
{ }^{\circ} \mathrm{C}=5 / 9\left({ }^{\circ} \mathrm{F}-32\right) \text {. }
$$

\section{SEA LEVEL}

In this report "sea level" refers to the National Geodetic Vertical Datum of 1929 (NGVD of 1929)—a geodetic datum derived from a general adjustment of the first-order level nets of both the United States and Canada, formerly called Sea Level Datum of 1929. 



\title{
HYDROGEOLOGIC FRAMEWORK OF THE PUGET SOUND AQUIFER SYSTEM, WASHINGTON AND BRITISH COLUMBIA
}

\author{
By JJ. VACCARO, A.J. HANSEN, JR., and M.A. JONES
}

\begin{abstract}
The Puget-Willamette Lowland is located in western Washington, western Oregon, and a small part of southwestern British Columbia, Canada. The aquifer systems contained within the Puget-Willamette Lowland are within two distinct areas-the Puget Sound Lowland and the Willamette Lowland. The study area for this report is the Puget Sound Lowland, which encompasses 17,616 square miles, 2,556 square miles of which is saltwater. The Puget Sound aquifer system underlies 7,300 square miles (41 percent) of the study area of which about 117 square miles is overlain by surface-water bodies. This report describes the hydrogeologic framework of the Puget Sound aquifer system.

Alluvial, glacial, and interglacial sediments of Quaternary age compose the aquifer system. The lateral extent of the aquifer system generally is delineated by the extent of the glacial drift of the youngest glaciation, the Fraser Glaciation. Excluding large lakes, of the Quaternary deposits present at land surface, alluvial deposits underlie 1,570 square miles, fine-grained deposits underlie 3,320 square miles, and coarse-grained deposits underlie 2,293 square miles. The coarsegrained deposits and alluvial deposits generally compose aquifer units, and the fine-grained deposits compose semiconfining to confining units. An alternating pattern of coarse- and fine-grained deposits occurs from land surface to depths locally of more than 3,300 feet. Tertiary and older rock units define the lateral and basal boundaries of the aquifer system, and together these units are called the basement confining unit.

Ground-water movement is from topographic highs to topographic lows. The direction of ground-water flow is predominantly

average annual precipitation, surficial geology, and land use and cover are dependent variables in linear regression.

The quality of water in the aquifer system is suitable for most uses. Dissolved solids generally are less than 150 milligrams per liter. Dissolved nitrate generally is less than 1 milligram per liter; locally large concentrations are attributed to land-use practices. Seawater has intruded some aquifers near the coast.

Six cross-sectional numerical models of ground-water flow were constructed to provide information to describe the major hydrologic and geologic controls on the ground-water flow system, to estimate the partitioning of recharge into discharge components, and to develop and test a conceptual model of the aquifer system. Information presented in the report and the results of the models together indicated that a simplified conceptual model of the aquifer system could be developed from a regional perspective. The simplified conceptual model allows for a description of the ground-water flow system. The conceptual model provides a framework in which regional hydrogeologic units could be identified.

On the basis of the conceptual model, regional glacial and interglacial aquifer, semiconfining, and confining units and alluvial valley aquifers were defined for the Puget Sound aquifer system. These regional hydrogeologic units consist of nine alluvial valley aquifers, the surficial semiconfining unit, the Fraser aquifer, the confining unit, the Puget aquifer, and the basement confining unit. Ground water in the aquifer system can be adequately described using these regional units. The alluvial valley aquifers constrain flow within the underlying and adjacent glacial deposits.
\end{abstract} lateral in aquifer units and vertical in the other semiconfining and confining units. Vertical gradients generally are downward, except near streams, rivers, and saltwater bodies, where they generally are upward. Ground water in the uppermost aquifer unit occurs under water-table conditions, and ground water in deeper units becomes increasingly confined with depth.

Flow within aquifer units indicates the existence of predominantly subregional flow systems. These systems are controlled by topography, the basement confining unit, and the extent of saltwater bodies; under the present hydrologic stress, there is no regional flow system.

Horizontal hydraulic conductivity of aquifer units generally ranges from about 10 to 700 feet per day, and median values are in the range of 15 to 50 feet per day. The vertical hydraulic conductivity of the glacial tills is estimated to range from about 0.001 to 0.01 feet per day, and the vertical conductivity of the fine-grained clayey interglacial units is on the order of 0.0001 feet per day.

Mean annual recharge to the aquifer system was estimated to range (using linear regression) spatially from nearly 0 to more than 70 inches per year and to average about 27 inches per year. The

\section{INTRODUGTION}

The U.S. Geological Survey initiated a Regional Aquifer-System Analysis (RASA) Program in 1978 in response to congressional concerns about the availability and quality of the Nation's ground water. The purpose of the RASA Program is to aid in the effective management of important ground-water resources by providing information on the hydrogeology and geochemistry of regional aquifer systems, as well as providing analytical capabilities necessary to assess management alternatives (Sun, 1986). The aquifer systems in the Puget-Willamette Lowland were chosen to be studied as part of this program. 
To meet the overall RASA Program goals, the major objectives of the Puget-Willamette Lowland study were to: (1) describe the geologic framework of the regional aquifer systems, (2) describe the hydrogeologic characteristics of the regional aquifer systems, (3) describe the regional ground-water flow system and its major hydrologic controls for each subarea, (4) estimate the water budgets for selected areas and use this information to describe the regional water budget, and (5) provide for a synthesis of knowledge of the two regional ground-water flow systems. A detailed description of the purpose of the study is given by Vaccaro (1992).

The Puget-Willamette Lowland regional aquifer-system study area is located in western Washington, western Oregon, and a small part of southwestern British Columbia, Canada (fig. 1). The study area is contained within a structural basin that extends from near the Fraser River, British Columbia, Canada, at about 49 degrees, 15 minutes latitude, to just south of Cottage Grove, Oregon, at about 44 degrees latitude. The PugetWillamette Lowland study area includes about $23,290 \mathrm{mi}^{2}$. The study area is comprised of two distinct subareas, the Puget Sound Lowland and the Willamette Lowland.

The study area for this report is the Puget Sound Lowland (fig. 2), which encompasses $17,616 \mathrm{mi}^{2}$, about $2,556 \mathrm{mi}^{2}$ of which is saltwater. The study area includes most of the Puget Sound drainage basin, which includes part of the Cascade Range and the Olympic Mountains, a small part of the Fraser River Basin in Washington and British Columbia, Canada, and small areas both south and southwest of the Puget Sound drainage. The part of the Puget Sound drainage basin not included is about $400 \mathrm{mi}^{2}$ of the upper Skagit River Basin north of Ross Lake in Canada (fig. 2).

The lateral extent of the principal aquifer units in the Puget Sound Lowland is defined by the area of outcrop of Quaternary sediments. These sediments underlie $7,183 \mathrm{mi}^{2}$ (41 percent) of the study area; this area does not include the extent of the sediments underlying saltwater and large lakes. The sediments, which are highly variable because of the area's complex geologic history, consist of alluvial, glacial, and interglacial deposits. These deposits consist principally of recent alluvium, recessional and advance outwash, till, and other glaciofluvial and interglacial sediments. The aquifer system contained in these sediments is herein named the Puget Sound aquifer system. Pre-Tertiary rock units and Tertiary sedimentary, volcaniclastic, volcanic, and metamorphic rock units overlie the remaining part of the study area $\left(7,760 \mathrm{mi}^{2}\right)$, and these units define both the lateral and basal boundaries of the aquifer system.

About 70 percent of the population of Washington reside within the study area, mainly in the metropolitan areas of Bellingham, Everett, Seattle and vicinity, Tacoma, and Olympia. A burgeoning population is increasing the demand for the available water. The population growth is mainly in the lowlands overlying the aquifer system, and the growing population not only has dramatically increased the demand for water but also has initiated conflicts over water supplies. In some areas, available water sources are already fully appropriated, and some supplies are limited because of contamination from human activities and saltwater intrusion from the Puget Sound and other saltwater bodies. Additionally, the population growth and the attendant changes in land use may detrimentally affect the quantity and quality of water that recharges the ground-water system.

The results of the Puget-Willamette Lowland study are presented in the U.S. Geological Survey Professional Paper 1424, Chapters A-D. Chapter A (Gannett and Caldwell, in press) presents the geologic framework for the Willamette Lowland aquifer system. The hydrogeologic framework for the Willamette Lowland aquifer system is presented in Chapter B (Woodward and others, in press). Chapter $C$ (Jones, in press) presents the geologic framework for the Puget Sound aquifer system. This report, Chapter D, describes the hydrogeologic framework of the Puget Sound aquifer system and is based on a synthesis and analysis of background and hydrologic information.

\section{PURPOSE AND SCOPE}

This report presents the generalized hydrogeologic framework of the Puget Sound aquifer system. The framework includes a conceptual model of the division of the aquifer system into regional hydrogeologic units for describing on a regional basis the ground-water flow in the Puget Sound aquifer system of the Puget Sound Lowland. The conceptual model is based on an analysis of historical data and on results of crosssectional numerical models of ground-water flow.

This report first describes background information on the regional physical, cultural (including water use), and geologic setting. Local hydrogeologic units present in the Puget Sound Lowland are then described. The ground-water flow system is described on the basis of preliminary regional water-level configurations and generalized aquifer-system geometry. Next, the report presents and synthesizes information on hydraulic characteristics. Estimates of mean annual recharge to the aquifer system are then presented. This section describes methods that have been used to estimate recharge, provides results including relations among water-budget components, discusses the method used 


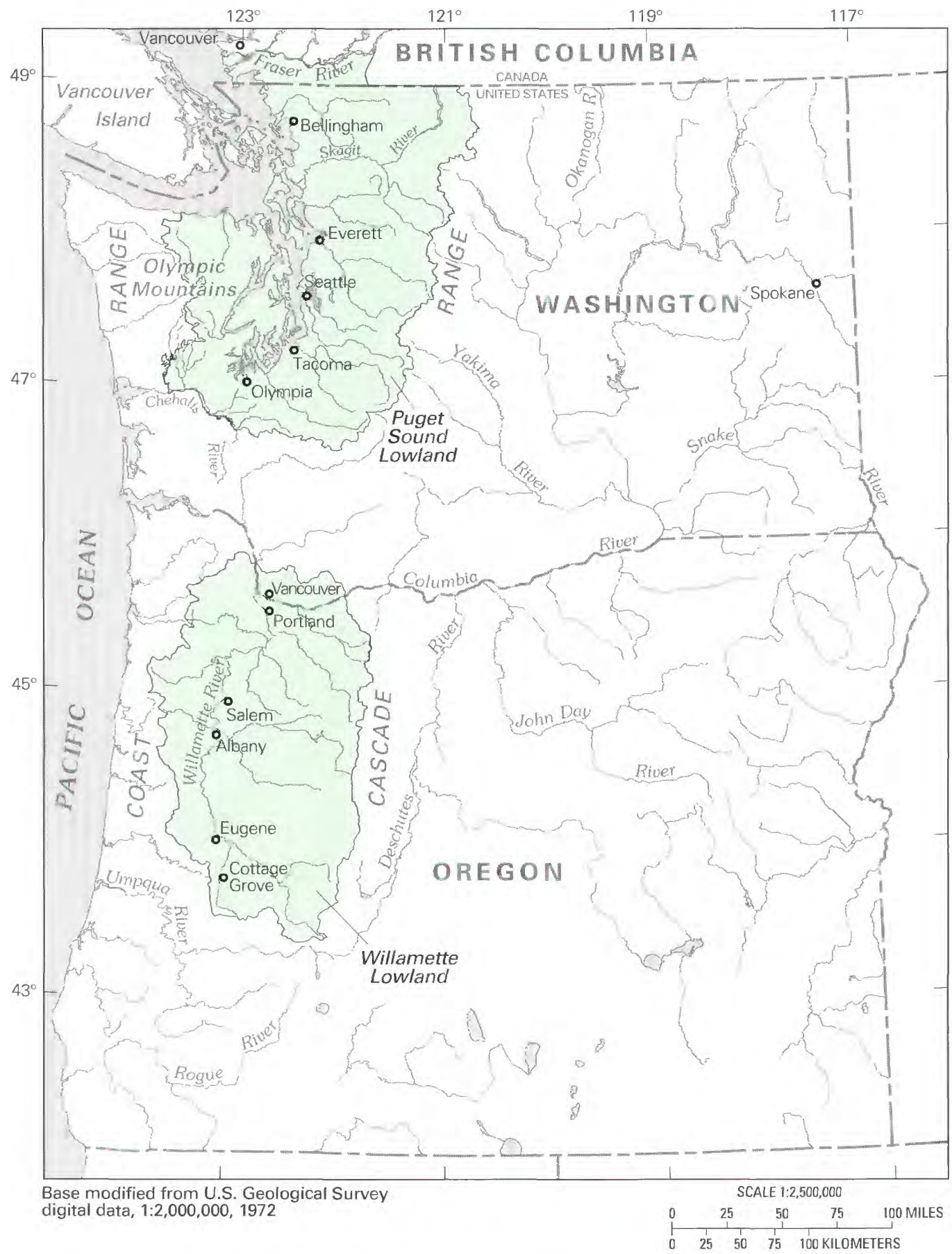

FiguRE 1.-Location of the Puget Sound Lowland and the Willamette Lowland, which make up the PugetWillamette Lowland regional aquifer-system study area. 


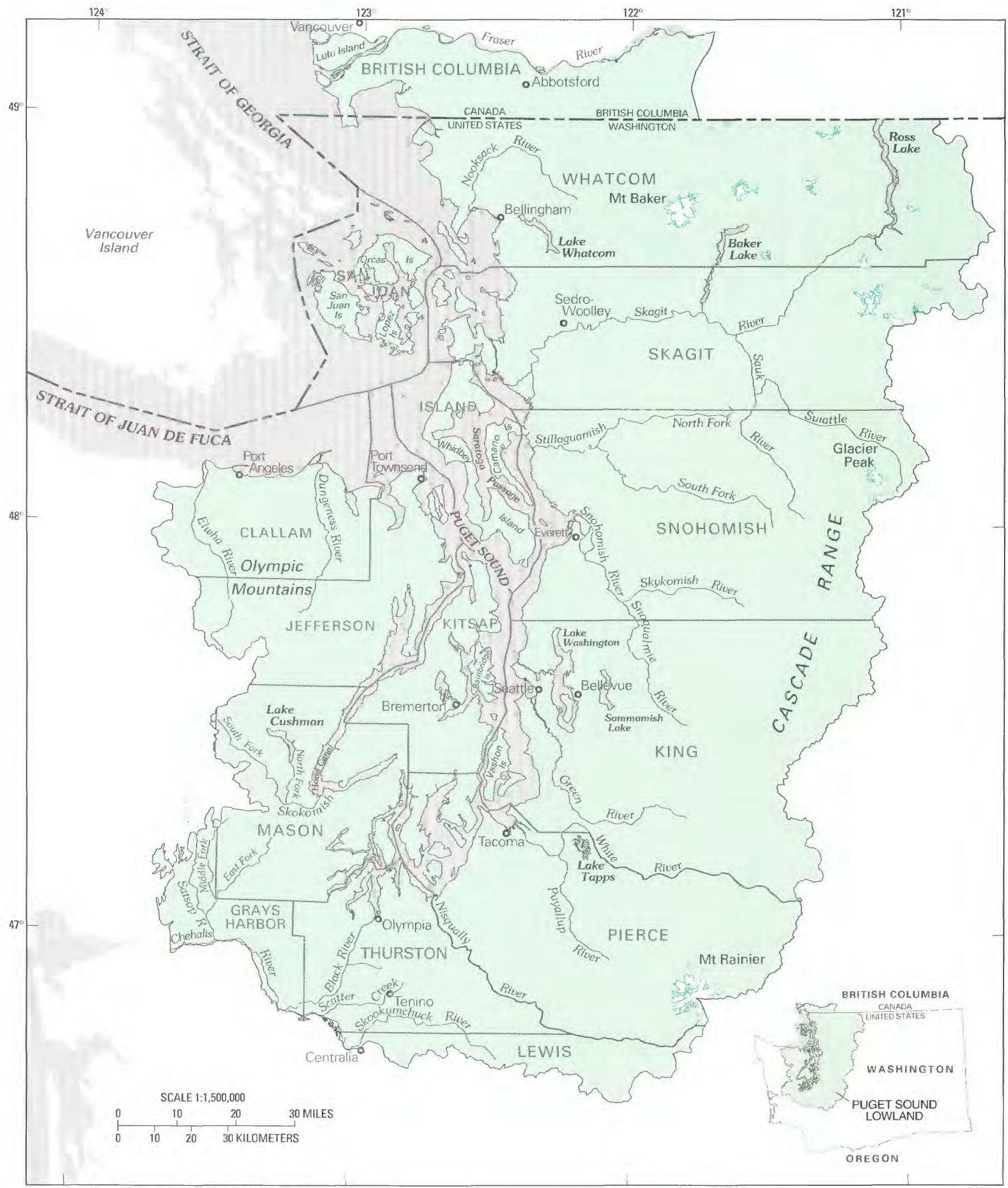


to estimate recharge for this study and the results of using this method, and discusses the reliability of the results. An overview of the water-quality characteristics of the aquifer system is then presented on the basis of historical data and previous investigations.

To improve understanding of the ground-water flow system and the major controls on the system and to help develop a simplified conceptual model for describing ground-water flow based on the division of the aquifer system into regional hydrogeologic units, numerical ground-water flow models were constructed for hydrogeologic sections in six "type" areas. The type areas were selected to determine the hydrologic control or effects of the configuration of the older basement units (the boundaries of the aquifer system) and the topography on the flow system and to analyze the effects of the wide range in hydrogeologic settings present in the Puget Sound Lowland on ground-water flow. The construction of the cross-sectional flow models is described, and aspects of the flow systems along the sections are then analyzed on the basis of the results of the flow models. The analysis considers the movement of water near and under saltwater bodies; topography; the configuration of the basement; fine-grained units; ranges in hydraulic characteristics; and the hydrologic aspects of flow systems and water budgets. The analysis compares results that are based on using a detailed definition of local hydrogeologic units (aquifer-system geometry) with results that are based on an aggregation of those hydrogeologic units. Last, a conceptual model for describing regional flow is described, and an example of the application of the model is presented.

For the purposes of this regional analysis and in the descriptions used in this report, certain terminology is used. The term "local" is used to describe flow or flow systems that are affected or controlled by topography and include lengths ranging from a few hundreds of feet to about 5 to $10 \mathrm{mi}$ and areas ranging up to about $10 \mathrm{mi}^{2}$ (encompassing areas that are on the order of about 0.1 percent of the total area of the aquifer system). The term "regional" is used in two ways. In the first way, "regional" is used throughout the report to denote (as necessitated by the purpose of this study) the regional scale of this study; thus, "regional aquifer system," "regionally representative value," and similar terms are used throughout the report. In the second way, "regional flow system" is used to denote flow or flow systems that contain flowpaths with lengths on the order of the average width of the aquifer system, about $40 \mathrm{mi}$. What may be a regional flowpath or system in a local study probably would be described as a subregional (intermediate) path or system in this study. This usage of "regional" generally is used in discussions of local in contrast to regional flow systems and paths.

\section{PREVIOUS INVESTIGATIONS}

The work of numerous investigators over the last 100 years has provided the basis for the study of the Puget Sound aquifer system. A list of the pertinent studies (Jones, 1991) was compiled as part of this investigation to assimilate the available information; many of the previous investigations are listed in the "Selected References" section of this report. A short summary of selected previous investigations related to geology, surface water, and ground water is given in the following paragraphs.

Willis (1898) provided the initial geologic overview of the sediments in the Puget Sound Lowland; he proposed the glacial origin of the Puget Sound and presented sedimentologic evidence for two continental glaciations. These he named the Vashon and Admiralty Glaciations, which were separated by the Puyallup interglaciation. Bretz (1910, 1911, 1913) surveyed the lowland in some detail, summarized the stratigraphic relations, included additional evidence for at least two continental glaciations (including more pre-Vashon sediments), and further concluded that the arms of Puget Sound were glacially modified river channels. Weaver (1937) established the geologic framework for further studies related to the Quaternary and Tertiary history of the area. Two later studies (Hansen and Mackin, 1949; Crandell and others, 1958) established that there was more than one pre-Vashon Glaciation and that there were four glaciations within the southern part of the Puget Sound Lowland. Later studies by Armstrong and others (1965), Easterbrook and others (1967), Easterbrook (1968), Thorson (1980), Booth (1984), and Blunt and others (1987) have greatly added to the understanding of the glacial history of the Puget Sound Lowland. More detailed information on the previous investigations of the geologic setting of the study area is given by Jones (in press).

Most of the earlier surface-water investigations in the study area analyzed the potential for hydropower development. Later investigations were more concerned with streamflow statistics and their relation to the construction of dams for water supply. It was not until the early 1970's that streamflow characteristics of selected streams were first analyzed. In his seminal paper, Gladwell (1970) described the relation between runoff and precipitation and watershed characteristics for western Washington. Starting with the reports of Hidaka (1973) for the Puget Sound region and Nassar (1973) for the Pacific Slope basins, the low-flow characteristics of streams in the Puget Sound Lowland were systematically analyzed. The later reports of Cummans (1977), Haushild and LaFrance (1978), and Williams 
(1987) documented the low-flow characteristics for much of the remainder of the Puget Sound Lowland.

Concurrently with these studies, Higgins and Hill (1973) described the stream-temperature data collected on all streams in Washington prior to 1968; the streamtemperature data were fitted by harmonic curves to define the annual time-temperature relation. The magnitude and frequency of flows were described by Bodhaine and Thomas (1964). As part of a Federal flood-insurance program, many streams in the area were mapped to estimate the recurrence intervals and stages of floods.

Water-quality and fisheries management issues also have spurred various surface-water investigations. For example, many counties established surface-waterquality management plans during the mid-1970's. Fishery studies have mainly addressed instream-flow assessment and utilization of streams by native and anadromous fish. Williams and others (1975) cataloged streams in the Puget Sound region on the basis of salmon utilization, and Swift $(1976,1979)$ calculated discharges of selected streams preferred by anadromous fish for spawning and rearing in Washington and the Puget Sound Lowland, respectively. The methods used by Swift were later supplanted by the more comprehensive Instream Flow Incremental Methodology (Bovee, 1982). This method was used by Embrey (1987) in the Stillaguamish River Basin and by Embrey (1991) for the Puyallup River Basin. Additionally, Ebbert and others (1987) assessed the quality of the water in the lower Puyallup River Basin as part of the latter fishery study.

The need to manage surface-water runoff spurred several investigations. Prych and Ebbert (1986) evaluated the quantity and quality of runoff based on data collected during 1979 to 1982 in three urban catchments in Bellevue, Washington. Dinicola (1990) developed regional rainfall-runoff relations for King County, Washington, during a watershed modeling study of five basins with 21 streamflow sites in King County. These regional relations were later used in another King County study of 11 basins (R.S. Dinicola, U.S. Geological Survey, oral commun., 1992) and were tested in studies in Thurston (Berris, 1995) and Pierce Counties (Mastin, 1996).

The principal surface-water inflow into Puget Sound was described by Williams (1984) in a map report. Many of the streamflow characteristics described by Williams were later summarized in two reports (Williams and others, 1985a,b). These two reports document the streamflow statistics and drainage-basin characteristics for all streams in the Puget Sound region that have been measured continuously by the U.S. Geological Survey.
Appraisals of the ground-water resources in the study area were begun as early as 1902 (Byers, 1902). A few years later, Landes (1905) compiled information on municipal water supplies, deep wells, and springs of Washington State on a county basis. Over the next 45 years there were few investigations, and the primary ground-water evaluations were the localized studies of Blair (1929), Piper (1930), Pardee (1931), Piper and La Rocque (1938), Robinson and Piper (1942), and Newcomb and others (1949). During the 1950's and 1960's, the U.S. Geological Survey, in cooperation with Washington State agencies, completed a series of areal ground-water studies that covered much of the Puget Sound Lowland. These studies were the first attempts to systematically categorize and quantify ground-water resources on a large scale. In some instances the same areas were studied by several investigators (see for example, Garling and others, 1965; Deeter, 1979; Hansen and Bolke, 1980). During the 1970's, the U.S. Geological Survey completed ground-water studies of nine Indian reservations in the Puget Sound Lowland (for example, Lum and Walters, 1976; Drost, 1979a,b; Walters and others, 1979; Drost, 1983b; Lum, 1984). Many localized studies have been completed by private companies for municipal well fields and ground-water contamination sites; these studies provide a wealth of site-specific information.

The first attempt to quantify the ground-water resources of the entire Puget Sound area was completed during the 1970's. The Puget Sound Task Force (1970) determined that the availability of ground water in the Puget Sound Lowland should be based on estimates of natural recharge to aquifers by the infiltration of precipitation. The Pacific Northwest River Basins Commission (1970) analyzed the Quaternary aquifer system in the Puget Sound Lowland as part of a comprehensive study of water and related lands of the Pacific Northwest region. Foxworthy (1979) provided an appraisal of the ground-water resources of both the Puget Sound region and the Willamette Valley in Oregon.

Countywide ground-water studies recently have been completed for San Juan County (Whiteman and others, 1983) and Island County (Sapik and others, 1988). During the 1980's and 1990's, the U.S. Geological Survey and other investigators, in cooperation with the State of Washington Department of Ecology, began a series of ground-water studies as part of the State of Washington Ground Water Management Area Program (GWMA). Halstead (1986) described the ground-water system for most of the part of the Puget Sound Lowland that lies within Canada.

Walters (1971) conducted a reconnaissance of seawater intrusion into the coastal aquifers in the Puget Sound Lowland during 1966-68; he identified local 
areas that were intruded with seawater. Dion and Sumioka (1984) reanalyzed Walters' work in 1978 to determine if the quantity and occurrence of seawater intrusion in the Puget Sound Lowland had increased; they concluded that the conditions in 1978 were similar to those of 1968.

\section{REGIONAL SETTING}

Pertinent background information on the regional setting is presented in the following sections. The overall physical setting is first described, including physiographic, climatic, and hydrologic information. Next, the regional cultural setting is described; this description includes a discussion of water use in the region. Last, the regional geologic setting is presented, providing the background information that is necessary for understanding the description of hydrogeologic units.

\section{PHYSICAL SETTING}

The Puget Sound Lowland is bordered by the Fraser River and the international boundary on the north, the Cascade Range on the east, and the Olympic Mountains on the west. North of the Olympic Mountains, the western boundary is defined by the Canadian-Washington border located in the waters south and east of Vancouver Island, British Columbia. The southern boundary of the Puget Sound Lowland is approximately defined by the extent of the Pleistocene glaciation, which is characterized by a series of low hills near the divide between the Puget Sound drainage basin and the Chehalis River Basin; however, for this study, the Puget Sound Lowland was defined to include part of the Chehalis River Basin-namely the drainages of the Black River $\left(136 \mathrm{mi}^{2}\right)$, Scatter Creek $\left(37 \mathrm{mi}^{2}\right)$, and the Skookumchuck River $\left(101 \mathrm{mi}^{2}\right)$ to the south and part of the drainage of the Satsop River and several small creeks to the west and southwest (fig. 2).

The Puget Sound Lowland is an elongated basin that extends about $200 \mathrm{mi}$ in a north-south direction; the lowlands range from about 15 to $80 \mathrm{mi}$ in width and average about $40 \mathrm{mi}$. Geologic structure (Gower, 1978; Cheney, 1987; Jones, in press) appears to separate the aquifer system into discrete ground-water basins. These basins are drained by rivers that carry water from the adjacent mountains to lowlands and then to Puget Sound, Hood Canal, and other saltwater bodies that are inland arms of the Pacific Ocean.

The topographic features in the Puget Sound Lowland are a result of repeated continental and alpine glaciation that has affected both erosion and deposition. The lowlands typically are alluvial river valleys with glacial outwash and till plains. These lowlands are separated from the bordering mountains by uplands with rolling hills and terraces. The transition from the lowlands to the uplands is abrupt in some areas; these areas are typified by steep bluffs. Numerous topographic features in the lowlands and uplands parallel the northsouth direction of past glacial advances. Except near the southern boundary, the transition from the uplands to the mountains is abrupt. Where the Olympic Mountains meet Hood Canal, there is an abrupt transition from the lowlands to the mountains.

Altitudes of the valley floors or lowlands range from sea level to about $500 \mathrm{ft}$. The uplands have altitudes ranging from 500 to about $1,500 \mathrm{ft}$. The mountains generally start at an altitude of about $1,500 \mathrm{ft}$ and extend to the crests of the Cascade Range and Olympic Mountains. The altitude of the crest of the Cascade Range averages about 7,500 ft, but a series of stratovolcanoes in the Cascade Range rise from about 8,000 to $14,000 \mathrm{ft}$ above sea level. The altitude of the Olympic Mountains averages about $3,000 \mathrm{ft}$, with many peaks between about 6,000 and $8,000 \mathrm{ft}$ above sea level.

The Puget Sound Lowland has a mid-latitude humid, Pacific Coast marine climate because of the easterly moving air masses from the Pacific Ocean. The adjacent mountains provide protection from the southward-moving Canadian cold-air masses and from the Pacific Ocean winter storms. As a result, both summer and winter temperatures are moderated; there is a distinct winter precipitation season and summer dry season; and altitude and location have a large effect on the distribution of precipitation and temperature. Climate characteristics for selected areas of the Puget Sound Lowland are shown in figure 3.

Within the lowlands, mean annual precipitation varies from about 16 to $19 \mathrm{in} / \mathrm{yr}$ in the "rain shadow" northeast of the Olympic Mountains in northeastern Clallam County to about 53 in/yr near Olympia, Washington (fig. $3 A$ ). In the Cascade and Olympic foothills, the precipitation ranges from 45 to about 60 in/yr, with the larger values being more typical of the Olympic foothills. Throughout the mountains, at altitudes between about 1,500 and $2,500 \mathrm{ft}$, precipitation ranges from about 60 to more than $100 \mathrm{in} / \mathrm{yr}$, and at higher altitudes, precipitation is generally more than $90 \mathrm{in} / \mathrm{yr}$. Excluding saltwater areas, mean annual precipitation for the study area (about $15,000 \mathrm{mi}^{2}$ ) is about $74 \mathrm{in}$. or about $82,000 \mathrm{ft}^{3} / \mathrm{s}$.

About 80 percent of the precipitation falls during the winter season (October through March; fig. 3B). Winterseason precipitation generally is rain below altitudes of about $1,000 \mathrm{ft}$, is both rain and snow at altitudes between about 1,000 to $1,500 \mathrm{ft}$, and is snow at higher altitudes. The summers are relatively dry; average July 

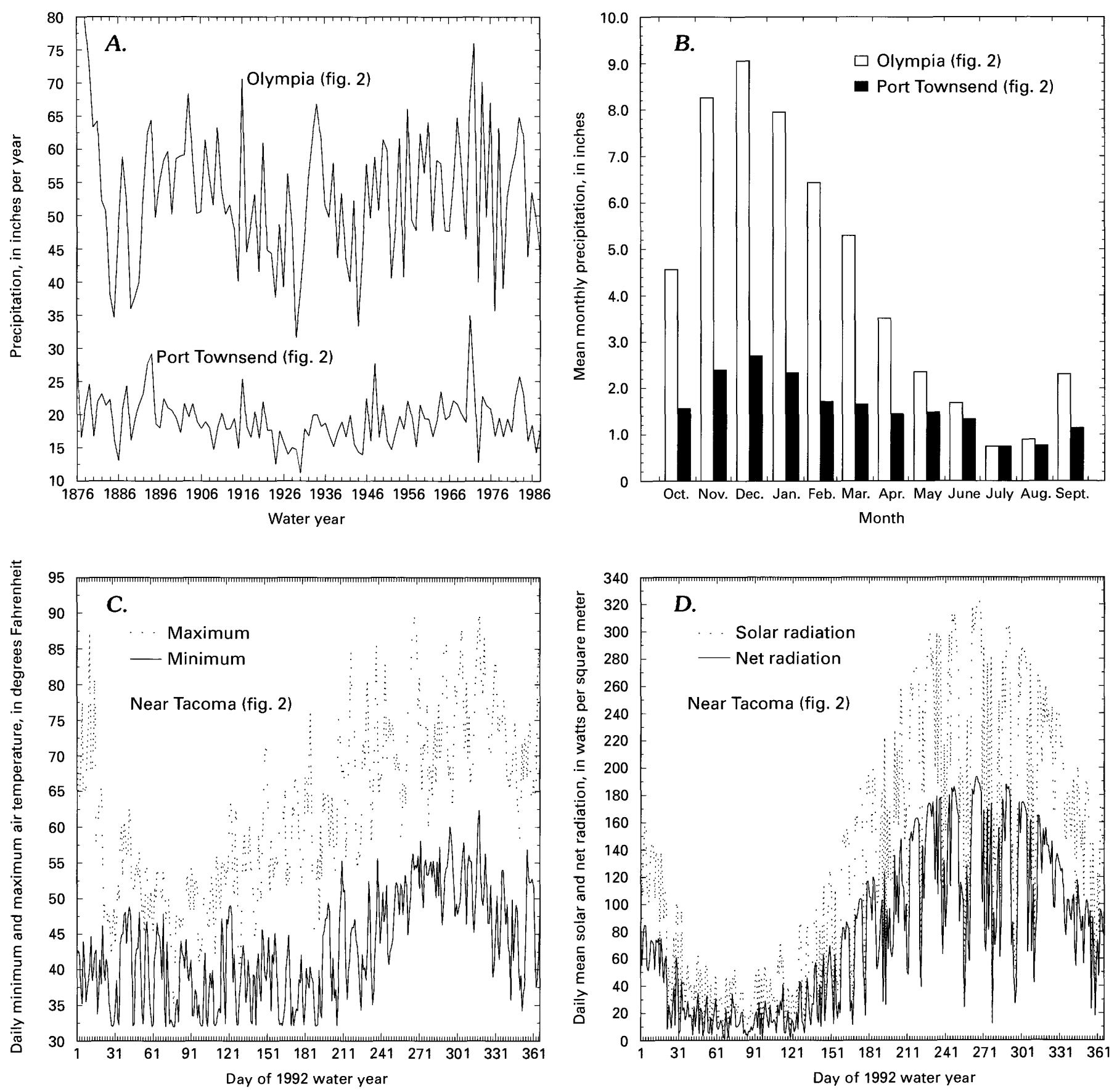

FIGURE 3.-Climate characteristics for selected areas in the Puget Sound Lowland- $(A)$ water-year precipitation, $(B)$ mean monthly distribution of precipitation, $(C)$ daily minimum and maximum air temperature, and $(D)$ daily mean solar and net radiation.

precipitation in the lowlands generally is less than about 0.75 in. (fig. $3 B$ ).

Mean annual daily maximum air temperatures range from about $60^{\circ} \mathrm{F}$ in the lowlands to about $47^{\circ} \mathrm{F}$ in the mountains, and mean annual daily minimum temperatures range from about $40{ }^{\circ} \mathrm{F}$ in the lowlands to about $31^{\circ} \mathrm{F}$ in the mountains (Puget Sound Task Force, 1970). Generally, summer temperatures in the lowlands range from 60 to $80{ }^{\circ} \mathrm{F}$, and winter temperatures range from 30 to $50^{\circ} \mathrm{F}$ (Puget Sound Task Force, 1970). Nighttime, below-freezing temperatures in the lowlands occur 20 to 90 days per year, and daytime freezing temperatures are generally limited to 10 to 20 days per year and occur during the winter (Puget Sound Task Force, 1970). Daily minimum and maximum temperatures collected during this study for a pasture site just 
southeast of Tacoma, Washington (fig. 3C), indicate the typical range and cycle in temperatures over a water year (October 1 to September 30) in the lowlands. Summer temperatures in the mountains are cooler than in the lowlands because they are moderated by the high altitudes; winter minimum temperatures in the mountains generally stay below freezing.

Solar radiation is the major control on evapotranspiration and thus on the regional water budget. Daily solar radiation is controlled by the time of year, landsurface slope and aspect, and cloudiness. The daily mean solar and net radiation over a water year measured at the pasture site southeast of Tacoma (fig. 3D) indicates the typical cycle in the lowlands. The incoming solar radiation provides a basis for the energy balance at the land surface, and net radiation provides a measure of that energy balance. The net radiation generally approximates the sum of sensible heat and evapotranspiration, and thus, the annual cycle of net radiation indicates the cycle and variations in evapotranspiration.

The Puget Sound Lowland can be divided into 20 complete and 2 partial drainages or hydrologic units (U.S. Geological Survey, 1976). For the larger rivers, the surface-water and ground-water basin boundaries probably are equivalent because of bedrock configuration and topography. The median annual surface-water runoff is about $51 \mathrm{in}$. $\left(50,000 \mathrm{ft}^{3} / \mathrm{s}\right)$, and median September runoff is about 22 in. $\left(21,600 \mathrm{ft}^{3} / \mathrm{s}\right)$; these values represent runoff from about $13,355 \mathrm{mi}^{2}$ of the Puget Sound Lowland (Williams, 1984), excluding Canada and the Chehalis River Basin in the Puget Sound Lowland. Runoff for the islands in the northern Puget Sound, which represent less than 3 percent of the total land area of the Puget Sound Lowland, averages about $10 \mathrm{in} / \mathrm{yr}$ (Puget Sound Task Force, 1970; Dietrich, 1975). However, runoff for most of the Puget Sound Lowland ranges from about 20 to $80 \mathrm{in} / \mathrm{yr}$. The runoff in parts of the Puget Sound Lowland is controlled by the presence of 386 glaciers, which cover about $116 \mathrm{mi}^{2}$ and contain about 13 million acre-ft $\left(3.85 \mathrm{mi}^{3}\right)$ of water. The glaciers help to provide consistent summer flows, especially in the Skagit, Nooksack, Puyallup, Elwha, and Nisqually River Basins.

\section{GULTURAL SETTING}

Native Indian villages were located near rivers in the Puget Sound region prior to the first settlement by non-Indians in the mid-1800's. By 1845 , only a few settlements had been established; these consisted of settlers in a small settlement near Olympia, scattered fur trappers, and Hudson Bay Company personnel. The
Territory of Washington was established in 1853, at which time the population was less than 5,000 settlers. Population increased to about 20,000 in 1870 and to about 350,000 in 1890 . The population growth occurred along rivers in the lowlands and within urban settlements such as Seattle, Olympia, Bremerton, and Tacoma. The dominant economic activity at this time revolved around timber. The building of the railroads and the gold rush to Alaska spurred rapid development and increased population growth between about 1895 and 1910. Many of the port and hydropower systems were established during this period. The rail and highway transportation systems allowed products to be shipped to market centers in other states and abroad. Additional growth in manufacturing resulted in a population in the Puget Sound Lowland of more than 500,000 by 1930 .

With the expansion of the military bases, wartime manufacturing, and the increasing development of timber and shipping resources in the 1940's, the population of the area expanded greatly. Rapid growth, from about 800,000 people in 1960 to about $2,200,000$ in 1979 , resulted in the conversion of more forest lands to urban and nonurban settlements and to agricultural lands. In 1967, cropland, urban, rural, and rangeland were the dominant land uses in the lowlands; however, forest land was the dominant land use mainly in that part of the lowlands bordered by the Hood Canal on the west and the Puget Sound on the east (fig. 2). The remainder of the lands in the Puget Sound Lowland at that time, some 80 percent, were still forest lands. Over 75 percent of these forest lands were, and still are, dedicated to commercial usage.

Population in the Puget Sound Lowland (excluding Canada) is expected to increase by more than 1.8 million from 1978 to 2020 , for a total of more than 4 million. Moreover, while the population of the major cities has grown only slightly since the early 1970 's, the population in the unincorporated parts of the counties has nearly doubled from 1970 to 1980 . As a result of the current growth, croplands, rangelands, and forest lands are being converted to commercial, city, and urban-suburban residential lands. The growth also has resulted in some diversification of the economic base, from predominantly timber and aerospace to include shipping, computer software development, manufacturing, and agriculture.

Regional water-use information compiled in three studies is presented in the following paragraphs; note that hydropower use is not included. However, because these studies defined the water-use categories differently, a direct comparison of this historical wateruse information cannot always be made. The largest water uses in the Puget Sound Lowland are for 
municipal, agriculture, and industrial purposes; water use for livestock generally is small.

In 1965, agricultural water use was about $202 \mathrm{Mgal} / \mathrm{d}$; municipal use was $219 \mathrm{Mgal} / \mathrm{d}$; and industrial use was about $431 \mathrm{Mgal} / \mathrm{d}$, about 75 percent of which was associated with the manufacturing of paper (Pacific Northwest River Basins Commission, 1971). Nonmunicipal domestic water use was only about $9 \mathrm{Mgal} / \mathrm{d}$ in 1965. Of the total water use in 1965 (about $861 \mathrm{Mgal} / \mathrm{d}$ ), about 85 percent was derived from surface-water sources, and the remainder $(129 \mathrm{Mgal} / \mathrm{d})$ from ground-water sources. On the basis of countywide information for 1975 (Dion and Lum, 1977), municipal water use appeared to be increasing and industrial water use decreasing for 1965-75. For example, Dion and Lum (1977) estimated that the 1975 municipal use was about $461 \mathrm{Mgal} / \mathrm{d}$ and industrial use about $316 \mathrm{Mgal} / \mathrm{d}$.

R.C. Lane (U.S. Geological Survey, written commun., 1992) has estimated water use in the Puget Sound region during 1990 as part of a nationwide assessment of water use. Lane estimated a total withdrawal of $810 \mathrm{Mgal} / \mathrm{d}$ for 1990 distributed by the following wateruse categories:

\begin{tabular}{lc}
$\begin{array}{l}\text { Water-use } \\
\text { category }\end{array}$ & $\begin{array}{c}\text { Quantity } \\
\text { (million } \\
\text { gallons per day) }\end{array}$ \\
\hline Domestic & 411 \\
Irrigation & 163 \\
Industrial & 131 \\
Commercial & 97 \\
Livestock & 8 \\
\hline
\end{tabular}

These estimates were for the part of the Puget Sound Lowland within the United States. About $497 \mathrm{Mgal} / \mathrm{d}$ of the total was from public supplies, of which about 35 percent $(174 \mathrm{Mgal} / \mathrm{d}$ ) was provided by ground-water sources and about 65 percent was provided by surfacewater sources. The remaining $313 \mathrm{Mgal} / \mathrm{d}$ was privately supplied-57 percent ( $178 \mathrm{Mgal} / \mathrm{d})$ from ground-water sources and 43 percent $(135 \mathrm{Mgal} / \mathrm{d})$ from surface-water sources. Whereas Dion and Lum (1977) considered industrial use to include most commercial use and considered municipal use to include principally domestic use, Lane has separated these quantities. However, industrial and commercial water use still appears to be declining, as does irrigation water use. Although domestic (municipal) water use appears to have decreased from 1975, Dion and Lum (1977) included other uses in their municipal category.

From 1965 to 1990, there has been an estimated reduction in total water use. This may be due to the reduction of large industrial uses such as the manufacturing of paper resulting from the conversion and diversification of the economic base of the region. However, for 1990, the estimate of water supplied from ground-water sources $\left(352 \mathrm{Mgal} / \mathrm{d}-545 \mathrm{ft}^{3} / \mathrm{s}\right)$ was nearly three times the quantity supplied from groundwater sources in 1965 . Additionally, for 1988, the estimate of water supplied from ground-water sources for the part of the Puget Sound Lowland in Canada was about $182 \mathrm{Mgal} / \mathrm{d}\left(281 \mathrm{ft}^{3} / \mathrm{s}\right)$ (B.C. Environment, 1993). Thus, about $532 \mathrm{Mgal} / \mathrm{d}$ or $826 \mathrm{ft}^{3} / \mathrm{s}$ of ground water was withdrawn for all uses.

As population and industrial growth continues, more water is being derived from ground water rather than from surface water, which is nearly fully appropriated. Much of the unappropriated surface water is far from the locations of need, and most new and smaller water-supply systems are using ground water as the source. The source of future supplies for the large and expanding municipal areas is not defined and is being vigorously debated.

\section{GEOLOGIC SETTING}

The regional geologic setting of the PugetWillamette Lowland is largely a function of plate tectonics. The western part of the Pacific Northwest is a region where the North American continental plate has been converging with the oceanic plates of the north Pacific Basin (fig. 4) throughout much of Cenozoic time (Atwater, 1970; Engebretson and others, 1985). Thus, the large-scale regional topography and geology are the products of tectonic convergence of the plates.

The Cascade Range is an active magmatic arc formed by the continuing subduction of the Juan De Fuca plate beneath the North American plate (fig. 4). Most of the western edge of the Cascade Range is bounded at depth by marine sedimentary and volcanic complexes of Eocene through Miocene age that have, in part, been accreted to the North American plate (Cady, 1975; Adams, 1984; Snavely, 1988). The Olympic Mountains, for example, are part of an exotic terrane, a remnant of the upper part of the descending oceanic plate that was scraped off the subducting plate, became attached to the leading edge of the North American plate, and then was uplifted; the mountains lie on the trench-slope break and are part of the trench system. The Puget-Willamette Lowland is a discontinuous valley that is a forearc basin, which commonly lies between the trench and magmatic arc (Dickinson, 1976) (fig. 4).

Pleistocene glaciation modified the regional geologic setting of the Puget Sound Lowland, and there have been several recognized glaciations and interglaciations 


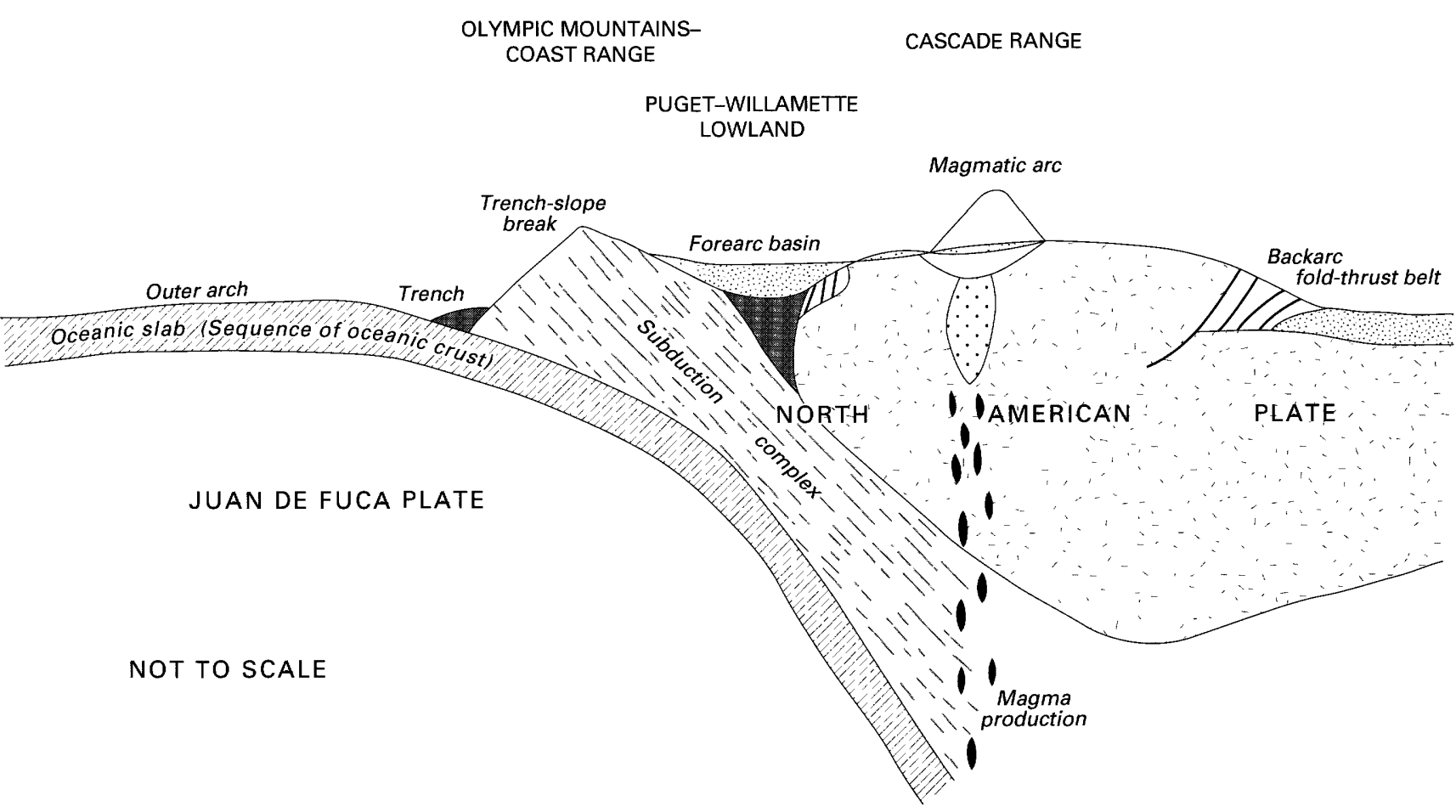

FIGURE 4.-Generalized tectonic features. Modified from Dickinson (1976).

(fig. 5). The Cordilleran ice sheet, which originated in the Coast Range in British Columbia, advanced into the Puget Sound Lowland at least four times, and several partial glacial advances have been identified in the northern part of the Puget Sound Lowland (Crandell and others, 1958; Armstrong and others, 1965; Blunt and others, 1987). For example, during the Sumas Stade of the Fraser Glaciation (fig. 5), the ice sheet readvanced a short distance into the northern Puget Sound Lowland about 11,500 years BP (before present) and totally retreated by about 9,500 years BP (Blunt and others, 1987).

The major advances of the ice sheets occupied most of the lowland areas and have extended laterally into the lower mountain valleys. About 18,000 years BP during the Vashon Stade, the last major advance of the Cordilleran ice sheet reached the northern limit of the Puget Sound Lowland and divided into two lobes (Thorson, 1980). The Juan de Fuca Lobe advanced westward about $120 \mathrm{mi}$ along the Strait of Juan de Fuca to a Pacific Ocean tidewater terminus, and the Puget Lobe advanced southward about $95 \mathrm{mi}$ into the Puget Sound Lowland between the Cascade Range and the Olympic Mountains. The Puget Lobe reached its maximum advance near the southern limit of the Puget Sound Lowland about 14,500 years BP, stagnated, and then began to retreat (Thorson, 1980; Blunt and others, 1987).
At its maximum extent, the Puget Lobe was about $60 \mathrm{mi}$ wide, nearly $4,000 \mathrm{ft}$ thick, and had a volume of about $3,350 \mathrm{mi}^{3}$ (Thorson, 1980, 1989). The Puget Lobe retreat allowed for a series of ice-dammed proglacial lobes to form in much of the lowlands. The Juan de Fuca Lobe retreated from the Strait of Juan de Fuca by about 14,500 years BP, allowing for the later draining of the proglacial lakes and the incursion of marine waters into the Puget Sound Lowland. The Puget Lobe probably retreated from its terminal position to near the latitude of Seattle, between 13,500 and 14,500 years BP (Thorson, 1980; Blunt and others, 1987). The Puget Lobe retreated about twice as fast as it has advanced (Booth, 1987). In turn, during this rapid final retreat of the Puget Lobe, the incursion of marine water allowed for floating and melting of the glaciers and the deposition of the glaciomarine drift during the Everson Interstade between about 11,000 to 13,500 years BP (fig. 5) (Blunt and others, 1987).

Alpine glacial advances originating in the Cascade Range and the Olympic Mountains also extended into the Puget Sound Lowland (Booth, 1987; Thorson, 1989). These alpine glacial advances generally were out of phase with the Cordilleran ice sheet. A good example of the alpine glacial advances and their asynchronous nature is from the Evans Creek Stade (fig. 5). With the onset of the Fraser Glaciation, alpine glaciers advanced 


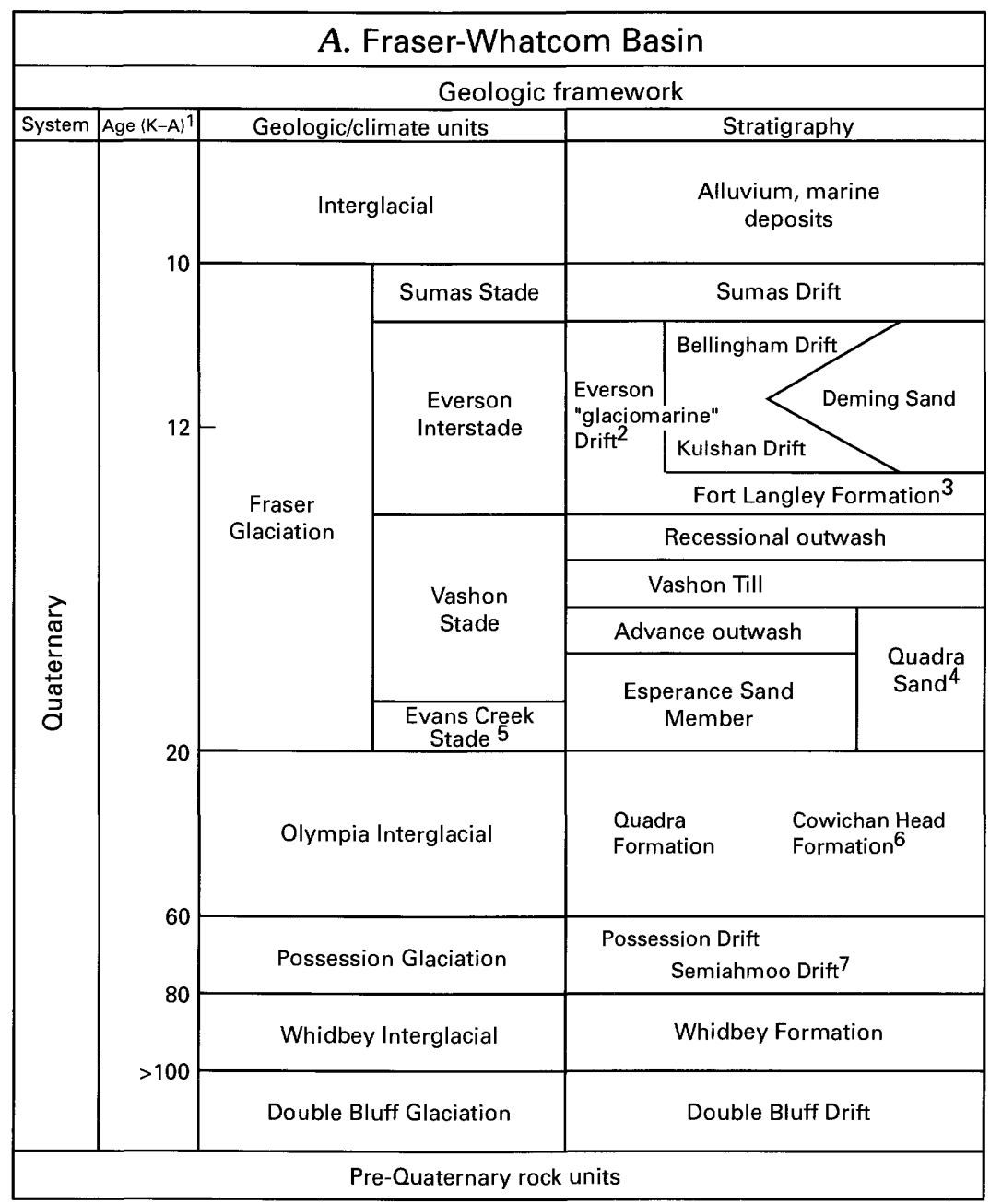

1 Radioactive age based on the determination of the potassium 40-argon 40 ratio; $>$, greater than.

2 Also includes glaciofluvial sediments-Everson sand (early Everson) and Everson gravel (late Everson).

3 Canadian name for Everson "glaciomarine" drift.

4 Canadian name for Vashon deposits older than till, although in many locations the unit does not include the advance outwash.

5 Deposit of similar age and older than Evans Creek Stade generally not exposed in basin, inferred from well-log information and from some exposures in Canada.

6 Canadian name for Olympia Interglacial deposits.

7 Canadian name for pre-Olympia Interglacial deposits.

FIGURE 5.-Framework for the regional correlation of hydrogeologic and stratigraphic units for the Puget Sound Lowland, $(A)$ Fraser-Whatcom Basin, (B) north-central Puget Sound Lowland, and $(C)$ southern Puget Sound Lowland. Location of areas shown in figure 6. Modified from D. Molenaar (U.S. Geological Survey, written commun., 1982), P.C. Haase (U.S. Geological Survey, written commun., 1988), Blunt and others (1987), and Glaster and Coombs (1989). Drift sequences separated by unconformities.

downward from the crest of the Cascade Range during this stade; this alpine glaciation was more pronounced in the northern Puget Sound Lowland than in the southern Puget Sound Lowland. The alpine glaciers subsequently retreated before the advance of the continental glacier (Armstrong and others, 1965). Alpine 


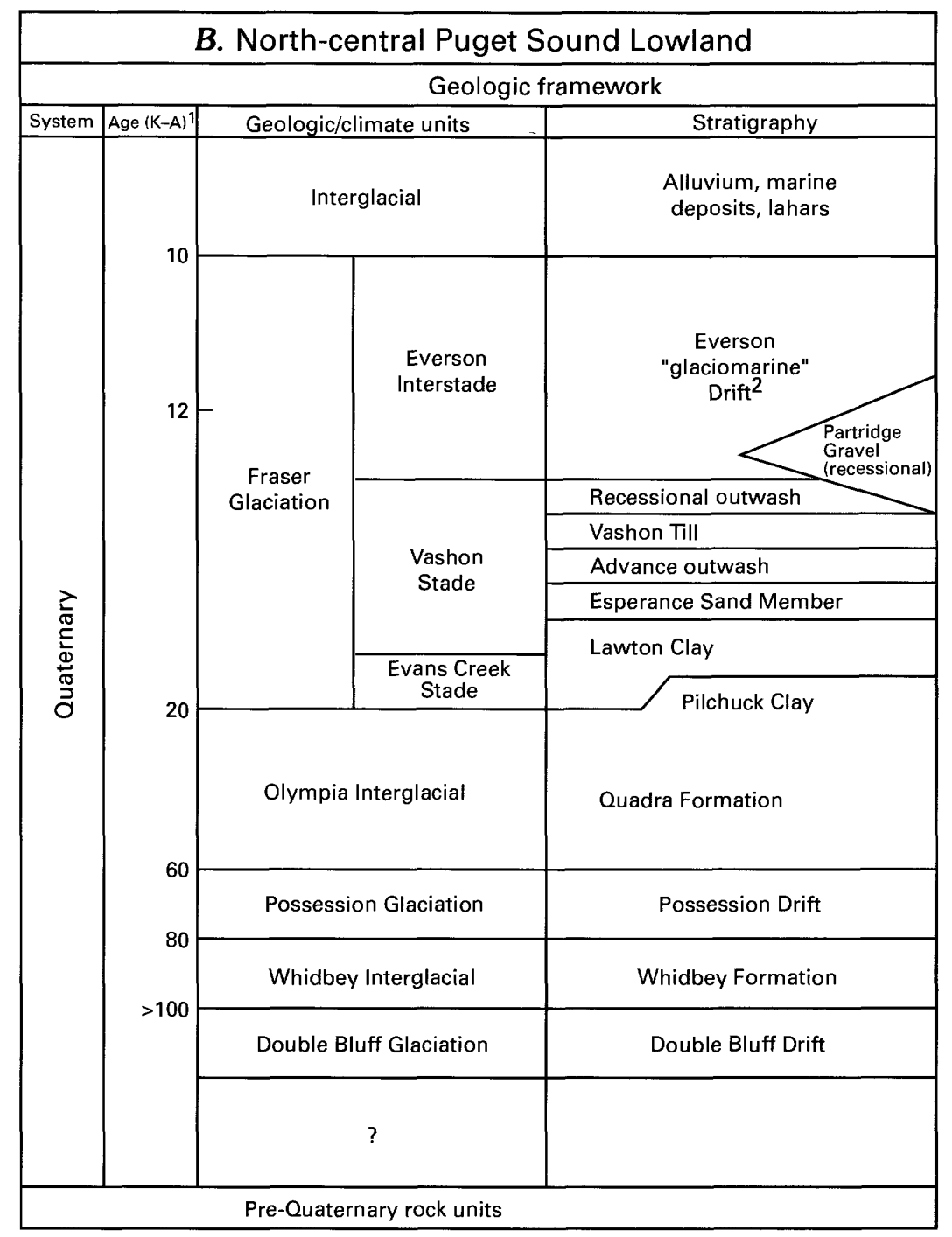

1 Radioactive age based on the determination of the potassium 40-argon 40 ratio; $>$, greater than.

2 Also includes glaciofluvial sediments-Everson sand (early Everson) and Everson gravel (late Everson).

FIGURE 5.-Framework for the regional correlation of hydrogeologic and stratigraphic units for the Puget Sound Lowland, (A) Fraser-Whatcom Basin, (B) north-central Puget Sound Lowland, and $(C)$ southern Puget Sound Lowland. Location of areas shown in figure 6. Modified fromD. Molenaar (U.S. Geological Survey, written commun., 1982), P.C. Haase (U.S. Geological Survey, written commun., 1988), Blunt and others (1987), and Glaster and Coombs (1989). Drift sequences separated by unconformities-Continued

glacial deposits are present at land surface mainly at the higher altitudes in the mountainous areas, predominantly in the southeastern part of the study area. In other areas, the Cordilleran ice sheet has overridden the alpine glacial deposits.

The lateral extent of the Puget Sound aquifer system is generally delineated by the extent of the drift deposited during the Fraser Glaciation (in particular, the Vashon Drift of the Vashon Stade). Except for the northern
Fraser-Whatcom Basin, most of the nonalluvial Quaternary deposits shown in the generalized surficial geologic map of the Puget Sound Lowland (fig. 6) belong to the Vashon Drift, which is relatively undisturbed. The Vashon Drift is associated with the advance and retreat of the Puget Lobe.

During the past and present interglacial periods, the major rivers emanating from the Cascade Range and the Olympic Mountains transported large quantities of 


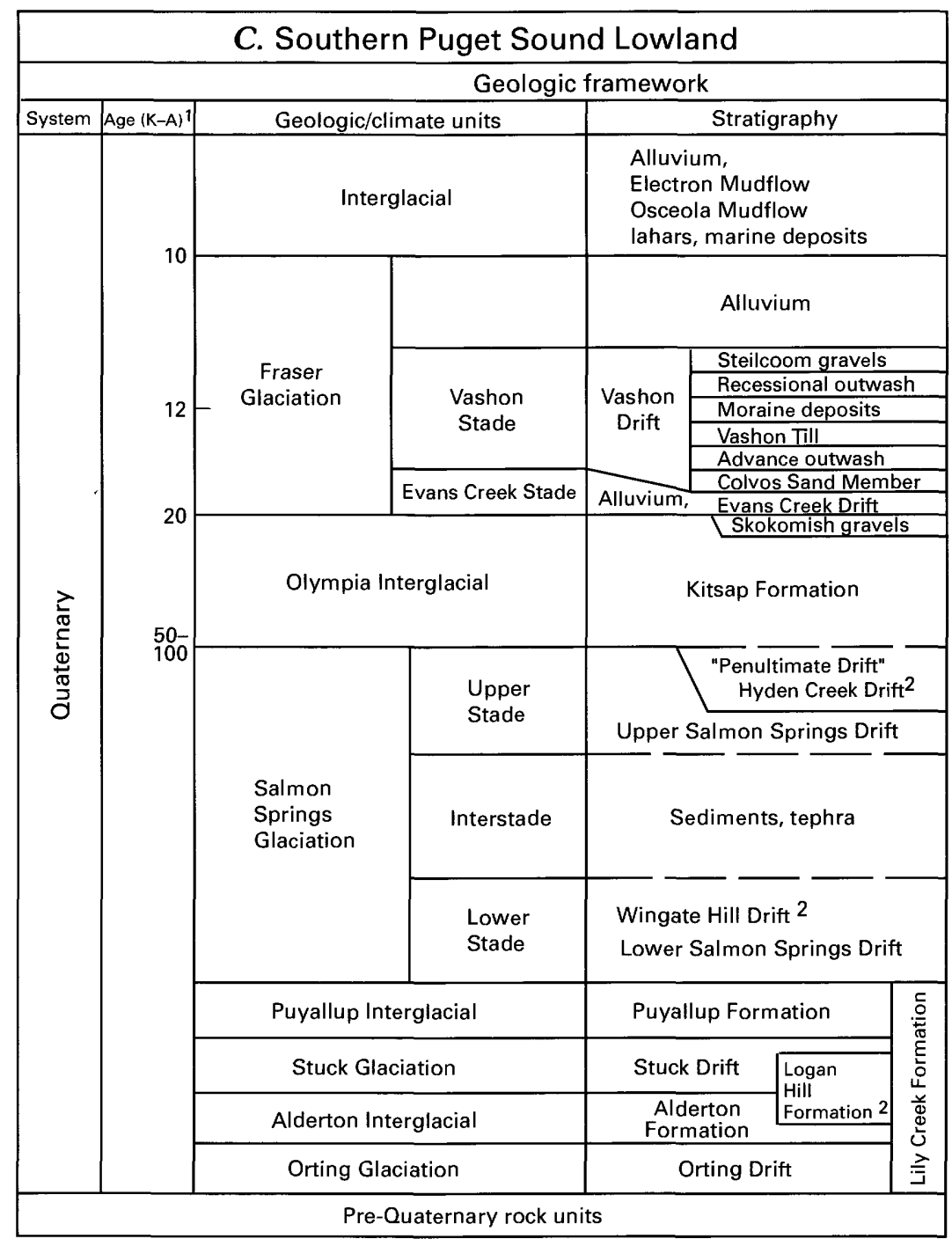

1 Radioactive age based on the determination of the potassium 40-argon 40 ratio; $>$, greater than.

2 Alpine glacial deposits generally located in mountainous areas of Cascade Range.

FIGURE 5.-Framework for the regional correlation of hydrogeologic and stratigraphic units for the Puget Sound Lowland, $(A)$ Fraser-Whatcom Basin, $(B)$ north-central Puget Sound Lowland, and $(C)$ southern Puget Sound Lowland. Location of areas shown in figure 6. Modified fromD. Molenaar (U.S. Geological Survey, written commun., 1982), P.C. Haase (U.S. Geological Survey, written commun., 1988), Blunt and others (1987), and Glaster and Coombs (1989) - Continued

sediments from the mountains to the lowlands. Alluvium was deposited along the large broad alluvial river valleys throughout the study area. Alluvial deposits in some of those valleys are more than $300 \mathrm{ft}$ thick. The orientation of many of these valleys suggests not only that they were glacially derived but also that they functioned as massive outwash channels.

As a result of the Holocene-Pleistocene geologic history, the Quaternary deposits consist of nonglacial sediments and one to four regional drift sequences and additional local sequences in parts of Whatcom County and British Columbia, Canada (the Fraser-Whatcom Basin); the sequences are generally separated by unconformities and by nonglacial fluvial and lacustrine sediments.

In a regional context, three types of deposits are associated with continental glaciers-advance outwash, till, and recessional outwash. The lateral and vertical extents of each of these types of deposits are best known for the Vashon Drift (fig. 5). In turn, the rapid retreat of 


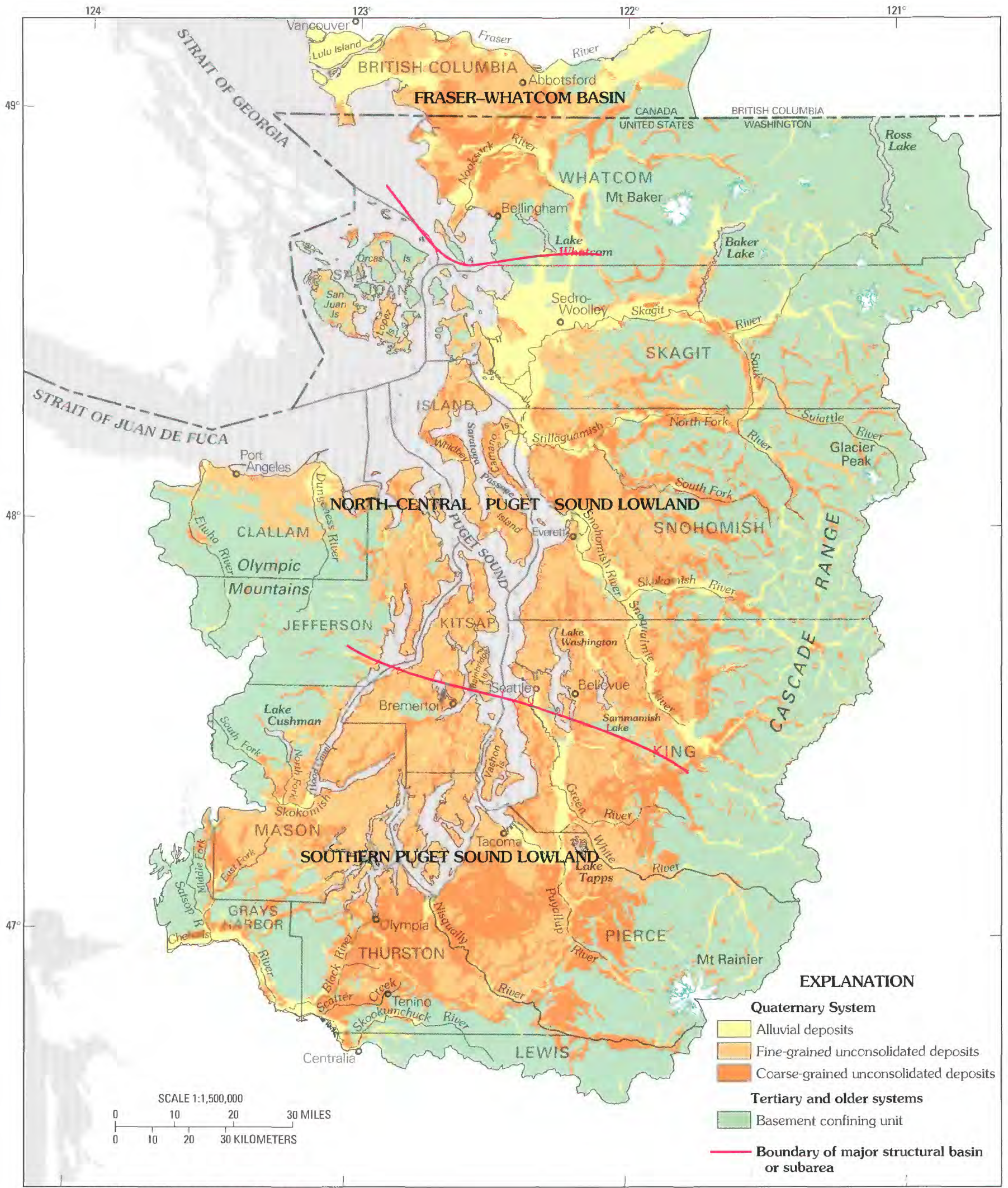

Base modified from U.S. Geological Survey

digital data, 1:2,000,000, 1972

FIGURE 6. - Generalized surficial geology of the Puget Sound Lowland and location of three major structural basins or subareas. 
the Puget Lobe is suggested by the extent of these types of deposits-a rather thin till sheet, large quantities of advance outwash compared to recessional outwash, absence of a significant terminal moraine, and similar age of recessional deposits along the path of retreat (Thorson, 1989). Although not glacially derived, proglacial deposits also are associated with glaciers. Generally, extensive proglacial units, such as the Colvos Sand and the Esperance Sand (fig. 5), have been aggregated with the advance outwash deposits in other investigations. Fine-grained, silty-to-clayey deposits generally are associated with interglacial or interstade periods; however, in some areas, the interglacial deposits are coarse grained. For the former case, the interglacial deposits generally are associated with deposition in bays or lakes, and for the latter case, the coarse-grained interglacial deposits generally are associated with fluvial depositional environments, typically along the periphery of the Quaternary deposits. Pre-Vashon age outwash, till, and interglacial type deposits generally are covered by deposits from younger glaciations and are more difficult to discern; exposures of these deposits are found along the coastline, cliffs, and erosional features. An idealized sequence of unconsolidated deposits in the Puget Sound Lowland is shown diagrammatically in figure 7.

Thus, at many locations there is a large sequence of alternating Quaternary fine-grained and coarse-grained deposits; the coarse-grained deposits generally are aquifer units, and the fine-grained deposits generally are semiconfining to confining units. These Quaternary deposits compose the Puget Sound aquifer system; the lateral extent of these deposits is shown in figure 6. Excluding large lakes, of the $7,183 \mathrm{mi}^{2}$ of unconsolidated deposits present at the land surface in the Puget Sound Lowland (fig.6), alluvial deposits overlie $1,570 \mathrm{mi}^{2}$, coarse-grained deposits (mainly recessional and advance outwash) overlie $2,293 \mathrm{mi}^{2}$, and finegrained deposits [mainly glacial till, but also parts of other deposits such as the Everson "glaciomarine" Drift (fig. 5) and mudflows] overlie $3,320 \mathrm{mi}^{2}$.

The interlayered drift and interglacial deposits overlie Tertiary and pre-Tertiary rocks in the Puget Sound Lowland. Generally, the pre-Tertiary rock units are the predominant units in about the northern one-half of the Puget Sound Lowland. These pre-Tertiary rock units and Tertiary marine and nonmarine sediments and volcanic rock materials compose the base of the aquifer system, which is herein named the basement confining unit. The total volume of unconsolidated deposits in the study area overlying the basement confining unit is about $1,315 \mathrm{mi}^{3}$; the unconsolidated deposits have an average thickness of about $400 \mathrm{ft}$ (Jones, in press).

Because of the partial glacier advances in the northern Puget Sound Lowland and the timing of the retreats of the ice lobes, the geologic framework varies across the study area. Therefore, the major stratigraphic units (fig. 5) for the Puget Sound Lowland are presented by

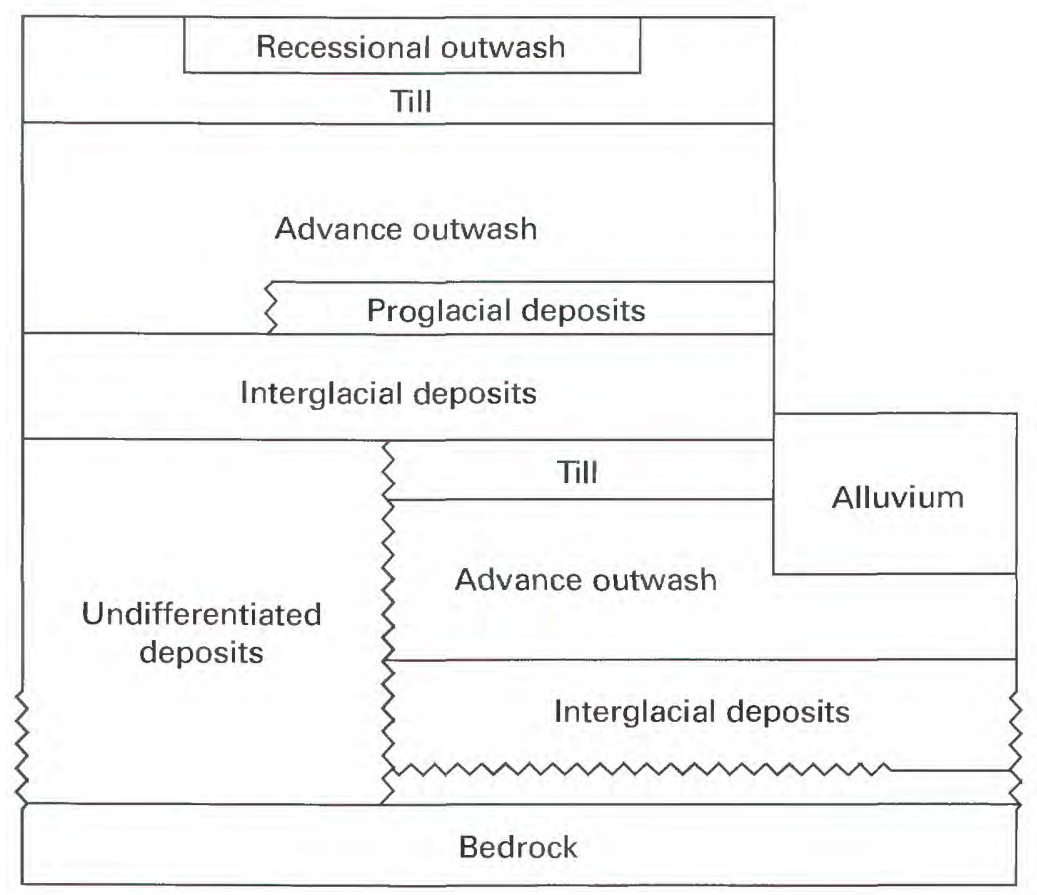

FIGURE 7.-Idealized sequence of unconsolidated deposits in the Puget Sound Lowland. 
subareas-the southern Puget Sound Lowland, the north-central Puget Sound Lowland, and the FraserWhatcom Basin (fig. 6). The second subarea represents a large structural basin that includes a combination of smaller structural basins (Jones, in press). The FraserWhatcom Basin (fig. 6) is a structural basin underlain by several thousands of feet of continental sediments. This basin is unique in that it is separated from the remainder of the study area by more than $20 \mathrm{mi}$ of bedrock uplands, and there have been more glacier advances in the basin than in the remainder of the Puget Sound Lowland. The generalized thickness of unconsolidated deposits composing the Puget Sound aquifer system (fig. 8) shows the relation between the three subareas, bedrock, and thickness.

The Puget Sound aquifer system is thus comprised of unconsolidated deposits that are locally more than $3,300 \mathrm{ft}$ thick (Hall and Othberg, 1974; Yount and others, 1985; Jones, in press) but average about $400 \mathrm{ft}$ thick (Jones, in press). The aquifer system consists of materials deposited: (1) by at least four advancing and retreating continental glaciations; (2) by numerous alpine glaciers emanating from the adjacent Cascade Range and Olympic Mountains and by streams during the alpine glaciations; and (3) by streams during interglacial (and glacial) episodes when much of the lowland consisted of saltwater embayments and freshwater lakes, including the present interglacial period. Each of these depositional regimes resulted in complex lithostratigraphic patterns and corresponding geologic units that are difficult to correlate on a regional scale. The complexity within each depositional sequence was compounded by the erosive action of the continental glaciers, which largely altered the pre-existing topography and geology. As a result, the classification of regional hydrogeologic units and correlation of these units with previously named stratigraphic and hydrogeologic units is complex, but it is important for incorporating the results of previous investigations.

Revisions in the chronology of the Pleistocene stratigraphic units proposed by Blunt and others (1987) suggest that previous correlations of stratigraphic units might be incorrect. However, hydrogeologic units are not necessarily time correlated; that is, stratigraphic and hydrogeologic units may be different. Additionally, the nomenclature for the stratigraphic units presented in figure 5 is representative of what is the most commonly accepted usage for major units; note that the nomenclature used for Bainbridge Island (fig. 2) generally follows the usage for southern Puget Sound Lowland (fig. 5) and not the north-central Puget Sound Lowland. The actual number of named units is more than 100, many of which have been identified or named during local or small-scale geologic investigations. Jones (in press) describes the relationship between some of these locally named units and (1) the major units presented in figure 5 and (2) regional units that are based on both depositional environment and lithology. This description applies only to the surficial units in the study area.

\section{HYDROGEOLOGY}

The following sections provide information on the hydrogeology of the Puget Sound aquifer system. This information is needed for developing a conceptual model to describe regional ground-water flow, for providing a framework for constructing numerical models of ground-water flow, and for synthesizing the available information for the aquifer system. Hydrogeologic units in the Puget Sound Lowland are first described. The ground-water flow system is then described by presenting general aspects of ground-water movement in the Puget Sound Lowland and pertinent background information. The regional flow system is described on the basis of generalized water-level configurations. Information on the hydraulic characteristics of the hydrogeologic units are presented and summarized; conclusions comparing representative regional values are discussed. Estimates of recharge and the methods used to derive them from both previous investigations and this study are described. Last, a summary of the historical water-quality characteristics is presented.

\section{HYDROGEOLOGIC UNITS}

For the purpose of this report, the Quaternary deposits in the Puget Sound aquifer system have been divided into aquifers and semiconfining to confining (nonaquifer) units. In comparison to confining units, semiconfining units generally have much smaller clay contents and, therefore, larger vertical hydraulic conductivities that allow for increased movement of water through them. In some locations, a confining unit may grade into a semiconfining unit either by a change in facies or by thinning. Thus, the difference between semiconfining and confining units is that the confining units generally are comprised predominantly of silt- to clay-size materials, whereas the silt- to clay-size materials in semiconfining units are generally less than about 30 percent of the weight.

The fine-grained, semiconfining to confining units generally consist of till, lacustrine, glaciomarine, and mudflow deposits (see Jones, in press). The coarsegrained aquifer units generally consist of outwash deposited during glacial (including alpine) advances and retreats, proglacial deposits, or alluvium deposited during glacial interstades. Because the hydrogeologic 


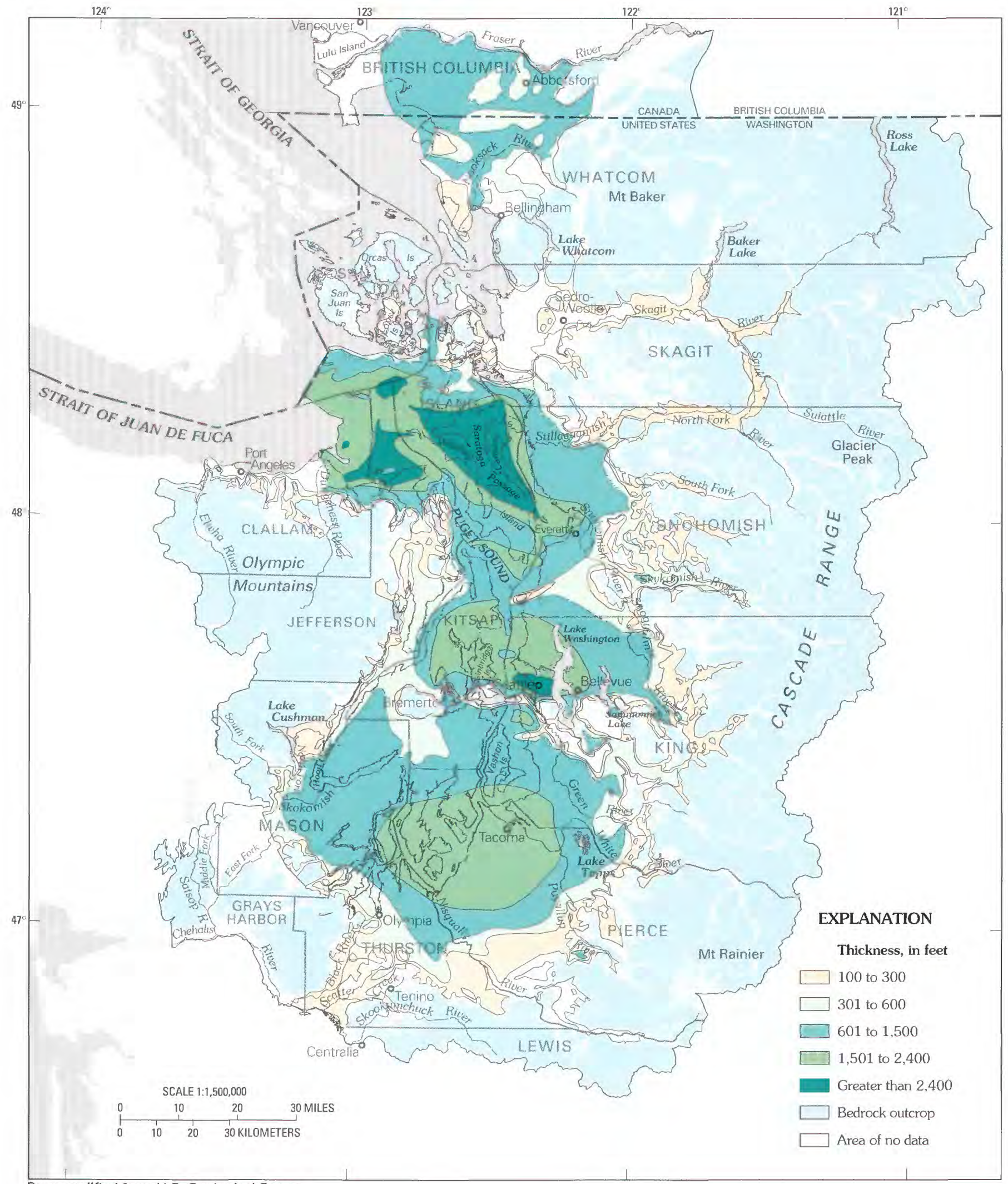

Base modified from U.S. Geological Survey digital data, 1:2,000,000, 1972

FIGURE 8.-Generalized thickness of the unconsolidated deposits composing the Puget Sound aquifer system. Modified from Jones (in press). 
units are mapped in this manner, the hydrogeologic units identified herein do not necessarily correspond to geologic time-stratigraphic units identified in previous reports that discuss the geology of the area. For example, geologic units composing the water-table aquifer in one area may be as much as 100,000 years older than the units composing the water-table aquifer in another area. Relations between regional hydrogeologic units and stratigraphic units are presented in Jones (in press) and are described later in this report. A summarized description of the local hydrogeologic units is provided below. Symbols in parenthesis (al) are used in table 9 later in this report.

1. (al) Recent (Holocene) alluvial deposits, present at the land surface, are represented by both small discontinuous deposits of alluvium scattered throughout the Puget Sound Lowland and extensive deposits in the broad alluvial valleys (fig. 6). Because of the latter, the alluvial deposits are treated as a separate hydrogeologic unit. This unit's lithology varies from fine grained to coarse grained. Where it is predominantly fine grained, lenses of sand and gravel found within the fine-grained facies function as aquifers. Thus, this unit generally can be classified as an aquifer to a semiconfining unit on the basis of its overall lithologic character. However, within the Puget Sound Lowland, this unit is more commonly coarse grained. Little information is available on the change in lithology of the unit with depth because of the sparse number of deep wells (greater than about $250 \mathrm{ft}$ deep). This unit generally is described separately from other interglacial deposits in this report and also is described separately in discussion of the sequence of glacial and interglacial deposits.

2. (Qr) The uppermost (surficial) deposits of glacial origin generally consist predominantly of the recessional outwash deposited while the glaciers were retreating during the last glaciation. These deposits are predominantly coarse grained. Locally, the finegrained facies include recessional marine and icecontact deposits. The recessional deposits generally are discontinuous within the Puget Sound Lowland, but where the deposits are sufficiently extensive, coarse grained, and saturated, they are considered an aquifer unit.

3. (Qt) An extensive till sheet mantles a large part of the Puget Sound Lowland; about 40 percent of the surficial Quaternary deposits are till. This predominantly fine-grained (averaging about 17-percent clay) till unit is comprised of unsorted and unstratified glacial sediments that vary in size from clay to boulder, in compaction, and in composition throughout the area. The till unit generally is classified as a nonaquifer (semiconfining) unit. However, where this unit is saturated, numerous shallow domestic wells obtain water from it. Although this unit is predominantly composed of the Vashon Till, about four other tills (including alpine glacial till) have been previously identified (Jones, in press).

4. (aq) Underlying the till unit are predominantly coarse-grained deposits. These deposits generally are associated with the deposits of the Vashon advance and proglacial periods, but in some areas these deposits are associated with Sumas, preFraser, and alpine glacial advance deposits. This unit was probably nearly continuous throughout the area at one time, but subsequent erosion has dissected it in many places. In some locations this unit is the surficial unit. Locally, this unit contains laterally mappable fine-grained zones and has been divided into a fine-grained (generally silty sand) and a coarse-grained unit. Where it has been divided on the basis of lithology, it has been classified as a sequence of aquifers and semiconfining units. Where the unit has not been divided in previous investigations, it has been classified as an aquifer unit.

5. (nonaq) The fine-grained interglacial or glacial and proglacial deposits are classified as nonaquifer units that typically function as semiconfining to confining units. Regionally, thick, laterally extensive deposits that are associated with interglacial periods generally are silt-to-clay units that function as confining units. These units may contain lenses of sand or gravel that locally function as aquifers. Additionally, in some areas there is a 20 - to 100 -ft thick distinct sequence of a clay-rich unit underlain by coarse-grained deposits, which in turn are underlain by another clay-rich unit. Along the periphery of the aquifer system, near the Olympic Mountains and Cascade Range, the interglacial deposits can be coarse grained. In these areas the units have been combined, if present, with the overlying coarsegrained deposits into a defined aquifer.

6. (undiv) The deeper undivided deposits generally occur about $250 \mathrm{ft}$ or more below land surface. The deposits consist of both glacial and interglacial materials; laterally extensive, clay-rich units (such as the Puyallup Formation; fig. 5) are known to occur within the deposits. These deposits generally 
are undifferentiated, and on a regional basis, the aggregated deposits function as an aquifer.

This alternating pattern of coarse- and fine-grained deposits occurs from the surface to depths of more than $3,300 \mathrm{ft}$ in the major structural basins. However, locally, information is only available from two locations that define the sequence of units 1 through 5 because most wells do not penetrate deeply into the system. In some areas, till deposits overlie or underlie fine-grained interglacial deposits and generally cannot be differentiated from interglacial deposits using well-log information. Thus, the tills and the fine-grained interglacial deposits in these cases may be grouped as one hydrogeologic unit. Conversely, when coarse-grained glacial and interglacial units are in direct contact, they also may be grouped as one hydrogeologic unit.

The thicknesses of the hydrologic units described above are highly variable, both locally and regionally. The recent alluvial deposits in the major river valleys vary from a few tens of feet in thickness in the upper reaches of the rivers to as much as $600 \mathrm{ft}$ in thickness in the lower reaches of some river valleys. The small discontinuous deposits of alluvium generally have thicknesses that range from about 5 to $10 \mathrm{ft}$. The localized, uppermost recessional outwash deposits generally average about $10 \mathrm{ft}$ in thickness. However, in a few areas, there are large, well-defined relic recessional outwash channels filled with coarse-grained deposits; these deposits can be up to $150 \mathrm{ft}$ thick but generally average about $40 \mathrm{ft}$. The thickness of the uppermost till unit reaches a maximum of more than $125 \mathrm{ft}$ in some locations and generally averages between about 20 to $40 \mathrm{ft}$. The thickness of the coarse-grained deposits below the upper till unit averages between about 20 to $50 \mathrm{ft}$. Although the thickness reaches a maximum of more than $400 \mathrm{ft}$ in some areas, a maximum of 150 to $200 \mathrm{ft}$ is more common. The underlying fine-grained deposits consist of silt- to clay-sized interglacial sediments or glacial till. Their thickness exceeds $150 \mathrm{ft}$ in some areas and averages between about 40 to $65 \mathrm{ft}$.

The above sequence of glacial and interglacial deposits generally comprises the upper $250 \mathrm{ft}$ or so of the aquifer system, and the deposits underlying this sequence generally are undifferentiated, especially on a regional basis. The extent and thickness of the waterbearing units in these undifferentiated deposits largely are unknown because water wells commonly penetrate only the upper $250 \mathrm{ft}$ of the total thickness (see table $2 A$ later in this report). Drillers' logs from a few deep exploratory wells drilled for petroleum or water are available, but these data are too sparse to adequately characterize the deep deposits throughout the Puget Sound Lowland. However, in some smaller areas, these deeper deposits can be divided into hydrogeologic units because of the availability of deep well information.

Hydrogeologic sections were constructed in six "type" areas that generally contain representative variations in the sequences of the hydrogeologic units present in the Puget Sound Lowland, as defined on a detailed, local basis and include many of the stratigraphic units described for the Puget Sound Lowland. The sections were constructed (Jones, in press) on the basis of thickness and structure contour maps prepared during local studies that divided the aquifer system into local hydrogeologic units. These sections show the subsurface distribution of the previously described hydrogeologic units, including the additional divisions. Because of the large size of the study area and the lack of data to describe the local hydrogeologic units on a regional basis, the "hydrogeologic type sections" were then used in analyses to: (1) provide information for describing ground-water flow in the Puget Sound Lowland, (2) develop a method to aggregate local units into regionally representative hydrogeologic units, (3) test hydrologic controls on ground-water flow, and (4) develop a conceptual model for describing regional ground-water flow based on the division of the aquifer system into regional hydrogeologic units. The generalized distribution of the units described above within each section are shown and discussed later (plate 1; table 9; in section on "Cross-Sectional Numerical Models of Ground-Water Flow"). Additionally, estimated correlations between local hydrogeologic and stratigraphic units for each section are given in table 9 later in this report.

\section{GROUND-WATER FLOW SYSTEM}

Regionally, ground water moves from topographic highs to topographic lows, which typically are stream drainages or saltwater bodies. That is, ground water moves from the glaciated uplands fronting the Olympic Mountains and Cascade Range to the surface-water drainages and to the saltwater bodies, and ground water moves from topographic highs on the peninsulas and islands in the Puget Sound Lowland to the saltwater bodies.

The direction of ground-water movement generally is horizontal in the aquifer units and vertical in the semiconfining to confining units. This overall pattern is affected by the hydrologic setting. Vertical gradients generally are downward, except near discharge locations, typically streams and saltwater bodies where gradients are upward; generally, ground water moves downward to deeper units in the high altitude recharge areas and upward from the deeper units to shallower 
units in the low altitude recharge areas. Ground water in the uppermost aquifer unit generally occurs under water-table conditions but may also occur under semiconfined conditions. For the glacial deposits, the water table may occur in recessional outwash, till, or advance outwash (either exposed at the land surface or directly underlying the till); the location of the water table is a function of the physical setting. Ground water in the deeper aquifer units generally occurs under semiconfined or confined conditions. Ground water in the aquifer units that are intermediate in depth between the uppermost and deeper aquifer units generally occurs both under water-table and confined conditions. The wide range in conditions under which ground water occurs is due to the highly variable extent of materials with similar lithologic characteristics.

Movement of ground water is controlled by topography, geometry of the aquifer system, and the distribution and rate of ground-water recharge and discharge. The configuration of the water table in the uppermost aquifer unit generally parallels the surface topography, and water levels generally are within about $100 \mathrm{ft}$ of land surface. The configuration of the potentiometric surface of each successively deeper aquifer unit is a more subdued replica of land surface. In aquifer units near or below sea level, the relation between the potentiometric surface and topography diminishes, and aquifer geometry and discharge locations (stream drainages and saltwater bodies) become more important controls.

Water levels in wells are a function of their topographic settings and the location of their open intervals within the flow system. In areas where the vertical movement of water is downward (generally high altitude areas), shallow wells will have water levels near land surface, and deeper wells generally will have water levels much below land surface. In areas where the vertical movement of water is upward (generally low altitude areas), shallow wells will have water levels near land surface, and deep wells generally will have water levels above either land surface or nearby surface-water bodies. Thus, at higher altitudes the water levels tend to decrease with depth, and at lower altitudes (near sea level) water levels tend to increase with depth. Generally, the depth to water in the uppermost aquifer units will be greater in areas of large topographic relief or high land-surface altitudes than in areas of small topographic relief or of low land-surface altitudes. Water levels in the aquifer units above sea level will vary from near sea level to land-surface altitude (maximum of about 800 to $1,000 \mathrm{ft}$ ), and water levels in the units below sea level will vary from sea level to a maximum altitude of about $250 \mathrm{ft}$.

Natural seasonal water-level fluctuations in the uppermost aquifer generally range from 1 to $10 \mathrm{ft}$; fluctuations are related to recharge, aquifer geometry, and lithology. Water-level fluctuations in the deeper aquifers generally are less than $4 \mathrm{ft}$. Fluctuations in shallow wells tend to show rapid response to recharge during the winter precipitation season and in deeper wells tend to show a lag of 1 to 3 months. Water levels in shallow aquifers generally start to rise in October to November, continue rising through the winter, and start to decline in late spring to early summer. Water levels in the deeper aquifers exhibit a more subdued and delayed fluctuation. Ground-water levels also fluctuate in response to tides. Tidal effects have been found to range up to $7.5 \mathrm{ft}$ and quickly approach $0 \mathrm{ft}$ at distances of 500 to $1,000 \mathrm{ft}$ from the shoreline (Lum and Walters, 1976; Drost, 1979a).

\section{BAGKGROUND}

Although general aspects of the ground-water flow system can be described, a regional assessment of the flow system has not been completed. Analysis of ground-water flow and availability in the Puget Sound Lowland has been completed at a variety of spatial scales in several areas (Jones, 1991; Vaccaro, 1992). However, the methods, descriptions, and division of the aquifer system into hydrogeologic units of previous investigators have varied widely. Additionally, the following factors indicate that the aquifer system may consist of several discrete ground-water flow systems contained in large ground-water (or structural) basins: (1) the configuration of the top of the basement confining unit (Jones, in press); (2) the presence and orientation of geologic structures (Jones, in press); (3) the presence and orientation of peninsular land bodies; (4) the size, depth, and north-south orientation of Puget Sound, Hood Canal, and other saltwater bodies; and (5) the numerous large, incised alluvial river valleys. Extrapolation of local results and analyses to a regional scale is, thus, difficult and problematic. For example, local results and analyses concerning ground-water recharge, stream-aquifer relations, and hydraulic characteristics may be transferrable on a regional scale, whereas descriptions of ground-water flow (horizontal and vertical gradients and quantities of water moving) may not be transferrable or are lacking. Because of the large size of the study area and the factors just discussed, it became apparent early in the study that a simplified, realistic method for describing regional groundwater flow was needed. Therefore, early in this study, available well information was analyzed, and results of this analysis are presented in the following paragraphs.

Table 1 presents a summary of the availability of well information in the U.S. Geological Survey's National Water Information System (NWIS) for the 
TABLE 1.-Availability of well information for the Puget Sound Lowland in the U.S. Geological Survey's National Water Information System as of 1990

\begin{tabular}{lccc}
\hline \multicolumn{1}{c}{ County } & Number of wells & $\begin{array}{c}\text { Number of wells } \\
\text { with water-level } \\
\text { information }\end{array}$ & $\begin{array}{c}\text { Number of wells } \\
\text { with land-surface } \\
\text { altitude, water- } \\
\text { level, and well- } \\
\text { depth information }\end{array}$ \\
\hline Clallam & 1,797 & 1,532 & 1,523 \\
Island & 2,194 & 1,971 & 1,652 \\
Jefferson & 289 & 224 & 215 \\
King & 4,356 & 3,492 & 3,407 \\
Kitsap & 2,989 & 2,374 & 2,353 \\
Mason & 562 & 380 & 364 \\
Pierce & 3,829 & 2,672 & 2,622 \\
San Juan & 428 & 334 & 305 \\
Skagit & 399 & 326 & 307 \\
Snohomish & 1,807 & 1,453 & 1,418 \\
Thurston & 4,231 & 3,518 & 3,475 \\
Whatcom & 1,586 & 1,254 & 1,189 \\
Total & 24,467 & 19,530 & 18,830 \\
\hline
\end{tabular}

Puget Sound Lowland as of 1990 , and tables $2 A$ and $2 B$ present selected descriptive statistics on that well information. Cursory examination of new well-drillers' logs that are not in NWIS indicates that the total number of wells in the Puget Sound Lowland is at least 30,000. The information (tables 1 and $2 A$ ) shows that although there are numerous wells in the Puget Sound Lowland, most of the wells are not deep; for example, 80 percent are less than $175 \mathrm{ft}$ deep. Although this indicates that the aquifer system is productive (the median discharge of 1,099 wells that had well-yield data and that were less than or equal to $50 \mathrm{ft}$ deep was $30 \mathrm{gal} / \mathrm{min}$ ), it also shows the paucity of available information for the deeper part of the aquifer system. Indeed, very few wells penetrate below $-200 \mathrm{ft}$ altitude.

The water-level data were examined to determine relations between well depth, land-surface altitude, depth to water, and generalized locations of recharge areas (land-surface altitudes greater than $50 \mathrm{ft}$ ) and discharge areas (land-surface altitudes equal to or less than $50 \mathrm{ft}$; table $2 B$ ). The definition of the generalized locations is based on the assumption that areas with altitudes of $50 \mathrm{ft}$ or less generally will be near the shorelines or in (or near) the alluvial valleys, both of which are discharge areas. The regression information (table 2B) indicates that a significant relation exists between the water-level altitude and land-surface altitude. This relation is typical for an aquifer system comprised of unconsolidated deposits and located in a humid climate. The relation shows the importance of topographic control on ground-water flow, at least for the upper 200 to $300 \mathrm{ft}$ of the aquifer system where most of the ground-water flow occurs-the "active" part of the system. In turn, the topographic control indicate potential importance of local flow systems and the potential usefulness of constructing, on the basis of well depth and incorporating land-surface altitude, generalized water-level maps for describing aspects of regional ground-water flow. The information in table $2 B$ also shows the nearly one-to-one relation between land-surface and water-level altitudes for wells less than $50 \mathrm{ft}$ deep. It was due to this relation and the fact that the best estimate of water levels would be land surface due to the accuracy of the topography contours at the scale $(1: 100,000)$ of the working maps used in this study that water levels from wells less than $50 \mathrm{ft}$ deep were not included for the construction of generalized preliminary water-level configuration maps. Also note that the relations between water-level and land-surface altitudes stratified by wells less than $51 \mathrm{ft}$ deep and wells greater than $105 \mathrm{ft}$ deep show that the downward vertical head gradient increases with increasing land-surface altitude (see fig. 9). When this well information is further stratified by land-surface altitude, the relations for altitudes less than $51 \mathrm{ft}$ (table $2 B$ ) generally indicate that water levels increase with well depth.

\section{WATER-LEVEL GONFIGURATIONS}

Generalized water-level configuration maps for the Puget Sound aquifer system were constructed at a scale of 1:100,000. Existing water-level information (both measured during previous studies and reported by well drillers) from the NWIS (table 1 and table $2 A$ ) was segregated by well depth into two categories-shallow (more than $50 \mathrm{ft}$ and less than $106 \mathrm{ft}$ ) and deep (more than $105 \mathrm{ft}$ ). Water-level maps then were constructed on the basis of those data, and the relations shown in table $2 B$; the water-level configurations for only the deep wells are presented in this report (fig. 10). Because the water-level information is not segregated by aquifer unit (that is, the geologic framework was not accounted for), the maps constructed in this manner are not suitable for addressing ground-water availability. Note that because of the general lack of wells deeper than $350 \mathrm{ft}$, the deep system described here generally represents, depending on location, the lower part of the aquifer unit that underlies the surficial till or the upper part of the deeper undivided deposits described in the previous section. Therefore, the water-level map (fig. 10) probably represents composite water levels from several local aquifer units or one or two regional aquifer units. Additionally, the lack of water-level data limit the ability to describe the deep flow system. However, the thickest parts of the aquifer system generally 
TABLE 2A. Descriptive statistics for well information

[values in feet, except as indicated]

\begin{tabular}{|c|c|c|c|c|c|c|c|}
\hline & \multicolumn{7}{|c|}{ Well information } \\
\hline & Well depth & $\begin{array}{l}\text { Well depth } \\
\text { greater than } \\
250 \text { feet }\end{array}$ & $\begin{array}{l}\text { Well depth } \\
\text { greater than } \\
500 \text { feet }\end{array}$ & $\begin{array}{l}\text { Land- } \\
\text { surface } \\
\text { altitude }\end{array}$ & $\begin{array}{l}\text { Water-level } \\
\text { altitude }\end{array}$ & Depth to water & $\begin{array}{l}\text { Bottom-of-well } \\
\text { altitude }\end{array}$ \\
\hline $\begin{array}{l}\text { Number of } \\
\text { wells }\end{array}$ & 23,344 & 2,264 & 364 & 22,910 & 18,830 & 18,830 & 18,830 \\
\hline Mean & 121 & 434 & 984 & 251 & 205 & 49 & 141 \\
\hline Minimum & 1 & 251 & 501 & 1 & 0 & 0 & $-2,500$ \\
\hline Maximum & 9,530 & 9,530 & 9,530 & 4,500 & 2,992 & 470 & 2,965 \\
\hline \multicolumn{8}{|l|}{ Percentile } \\
\hline 10 & 19 & 264 & 524 & 40 & 11 & 3 & -57 \\
\hline 20 & 32 & 277 & 546 & 80 & 38 & 7 & -16 \\
\hline 30 & 49 & 295 & 575 & 121 & 75 & 10 & 20 \\
\hline 40 & 65 & 310 & 610 & 160 & 113 & 16 & 62 \\
\hline 50 & 84 & 328 & 672 & 200 & 154 & 24 & 102 \\
\hline 60 & 105 & 356 & 750 & 250 & 198 & 37 & 146 \\
\hline 70 & 134 & 396 & 825 & 320 & 270 & 56 & 216 \\
\hline 80 & 175 & 460 & 992 & 400 & 345 & 84 & 298 \\
\hline 90 & 250 & 604 & 1,230 & 502 & 458 & 132 & 412 \\
\hline
\end{tabular}

TABLE 2B. Descriptive statistics for well information and regression information

[values in feet, except as indicated; WD, well depth; LSA, land-surface altitude; DtW, depth to water; WL, water-level altitude; $\quad R^{2}$, regression correlation coefficient squared]

\begin{tabular}{|c|c|c|c|c|c|c|c|c|}
\hline \multirow[b]{2}{*}{ Slope } & \multicolumn{2}{|c|}{ WD vs LSA } & \multicolumn{2}{|c|}{ DtW vs LSA } & \multicolumn{2}{|c|}{ DtW vs WD } & \multicolumn{2}{|c|}{ WL vs LSA } \\
\hline & 0.0251 & & 0.0376 & & 0.288 & & 0.962 & 0.868 \\
\hline Intercept $^{1}$ & 113.7 & & 39.34 & & 16.25 & & -39.34 & 0 \\
\hline \multirow[t]{2}{*}{$\mathrm{R}^{2}$} & .0007 & & .0162 & & .2930 & & .9154 & .951 \\
\hline & \multicolumn{2}{|c|}{ WL vs LSA ${ }^{2}$} & \multicolumn{2}{|c|}{ WL vs LSA ${ }^{3}$} & \multicolumn{2}{|c|}{ WL vs LSA ${ }^{3}$} & \multicolumn{2}{|c|}{ WL vs LSA ${ }^{4}$} \\
\hline Slope & 0.951 & 0.771 & 0.993 & 0.942 & 0.998 & 0.961 & 0.960 & 0.722 \\
\hline Intercept $^{1}$ & -76.5 & 0 & -20.69 & 0 & -11.55 & 0 & -100.1 & 0 \\
\hline \multirow[t]{2}{*}{$\mathrm{R}^{2}$} & .87 & .904 & .988 & .992 & .992 & .996 & .83 & .87 \\
\hline & \multicolumn{2}{|c|}{ WL vs LSA ${ }^{6}$} & \multicolumn{2}{|c|}{ WL vs LSA ${ }^{7}$} & \multicolumn{2}{|c|}{ WL vs LSA ${ }^{7}$} & \multicolumn{2}{|c|}{ WL vs LSA ${ }^{8}$} \\
\hline Slope & 0.723 & 0.483 & 0.9802 & 0.868 & 0.860 & 0.723 & 0.600 & 0.750 \\
\hline Intercept $^{1}$ & -8.59 & 0 & -47.1 & 0 & -4.85 & 0 & 5.45 & 0 \\
\hline $\mathrm{R}^{2}$ & .152 & .33 & .9088 & .952 & .725 & .914 & .302 & .807 \\
\hline
\end{tabular}

$\mathbf{1}_{\text {Intercept }}=0$ indicates regression constrained such that regression line passes through zero.

${ }^{2}$ Wells greater than 105 feet deep. $\quad{ }^{3}$ Wells less than 106 feet deep. $\quad{ }^{4}$ Wells less than 50 feet deep.

5 Wells greater than 105 feet deep and land-surface altitude greater than 50 feet.

${ }^{6}$ Land-surface altitude equal to or less than 50 feet. ${ }^{7}$ Land-surface altitude greater than 50 feet.

8 Land-surface altitude less than 51 feet and wells less than 50 feet deep.

${ }^{9}$ Land-surface altitude less than 51 feet and wells greater than 105 feet deep. 


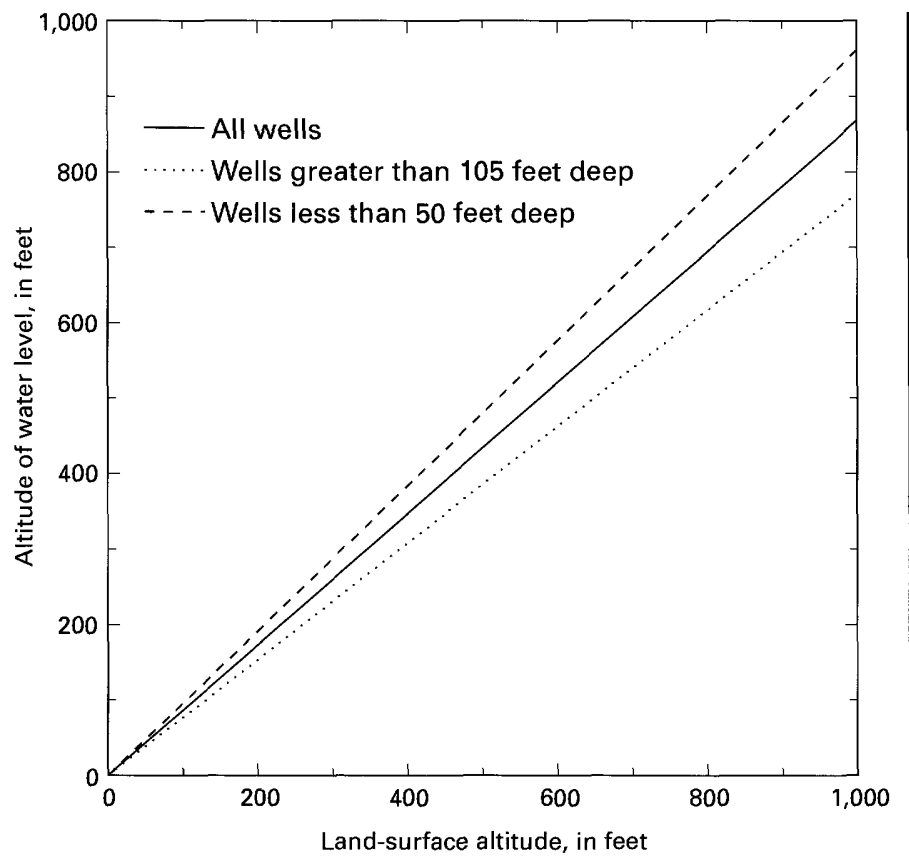

FIGURE 9.--Linear relations between water-level altitude and land-surface altitude.

underlie saltwater bodies that may limit flow in such a system.

The water-level maps were used to obtain an initial understanding of the range of horizontal and vertical head gradients present in the aquifer system, and the generalized regional direction of ground-water movement. The maps were also used, in conjunction with basement structure contours (Jones, in press), to estimate whether geologic structure possibly separates the aquifer system into discrete ground-water basins and, thus, subregional flow systems.

Although the geologic structures, the configuration of the basement confining unit, and the thickness of the aquifer system indicate about six distinct structural basins (Jones, in press), information provided by the water-level configurations cannot be used to infer six ground-water basins. However, the water levels in conjunction with the overall geology of the aquifer system indicate, on a regional basis, that there are at least three ground-water basins whose boundaries generally correspond to the subareas (Fraser-Whatcom, northcentral, and southern) shown in figure 6. Additionally, within each of these basins there does not appear to be a consistent flow system-only isolated local to subregional flow systems that contain flowpaths that do not traverse a complete basin. This corresponds to results from local investigations; for example, Woodward and others (1995) in a study of part of King County define a regional flow system existing only in the bedrock units.
Additionally, the north-south orientation of the major saltwater bodies and the landforms of the Puget Sound Lowland, the large depths of the saltwater bodies (the low areas in the Puget Sound Lowland near where flowpaths in the deepest parts of the system will generally end), and the overall orientation of the waterlevel surfaces together indicate that discrete areas of the Puget Sound aquifer system can be analyzed without regard to other areas because not all areas are hydraulically connected. Thus, on the basis of overall physical setting (for example, see fig. 8) and the information shown in figure 10, there does not appear to be a regional ground-water flow system.

The water-level configurations based on the shallow well information showed that ground-water flow is toward streams and saltwater bodies (surface-water features). The flow systems represented by these contours generally are similar to those presented in figure 10 and typify local flow systems supported by local recharge and controlled by topography and surface-water features. Most horizontal head gradients range from 10 to $100 \mathrm{ft} / \mathrm{mi}(0.002$ to $0.02 \mathrm{ft} / \mathrm{ft})$ and, on a regional basis, average about $35 \mathrm{ft} / \mathrm{mi}(0.007 \mathrm{ft} / \mathrm{ft})$. Average gradients are least in coarse, recessional outwash and alluvial deposits and are steepest in fine-grained deposits. Gradients are steeper (as much as $500 \mathrm{ft} / \mathrm{mi}$ or $0.09 \mathrm{ft} / \mathrm{ft}$ ) in steep terrain areas and near bluffs and cuts; in these areas, gradients average about $200 \mathrm{ft} / \mathrm{mi}(0.04 \mathrm{ft} / \mathrm{ft})$. The steeper gradients show both the topographic and boundary-condition control at bluffs and cuts where units are truncated.

The water-level configuration in the deeper aquifer system (fig. 10) shows that the principal direction of ground-water flow is toward surface-water features. Although topography is still a major control, the waterlevel surfaces generally are flatter than those in the shallow aquifer system and are a more subdued replica of land surface. As a result, horizontal head gradients also are smaller and typically range from 10 to $40 \mathrm{ft} / \mathrm{mi}$ $(0.002$ to $0.008 \mathrm{ft} / \mathrm{ft})$ and, on a regional basis, average about $25 \mathrm{ft} / \mathrm{mi}(0.005 \mathrm{ft} / \mathrm{ft})$. Again, steeper gradients typically are located in steep terrain areas or near bluffs and cuts. Horizontal gradients near saltwater bodies range from 10 to $30 \mathrm{ft} / \mathrm{mi}(0.002$ to $0.006 \mathrm{ft} / \mathrm{ft})$ and generally are less than the gradients in the shallow system. The estimated gradients are very similar to those reported in detailed local studies of individual aquifer units (for example, Hart Crowser and Associates, 1986; Sapik and others, 1988; Turney and others, 1995; Woodward and others, 1995).

Horizontal head gradients in the alluvial deposits in the major river valleys are flatter than most gradients in the glacial and interglacial deposits in the adjacent uplands; for example, see the water-level contours in 


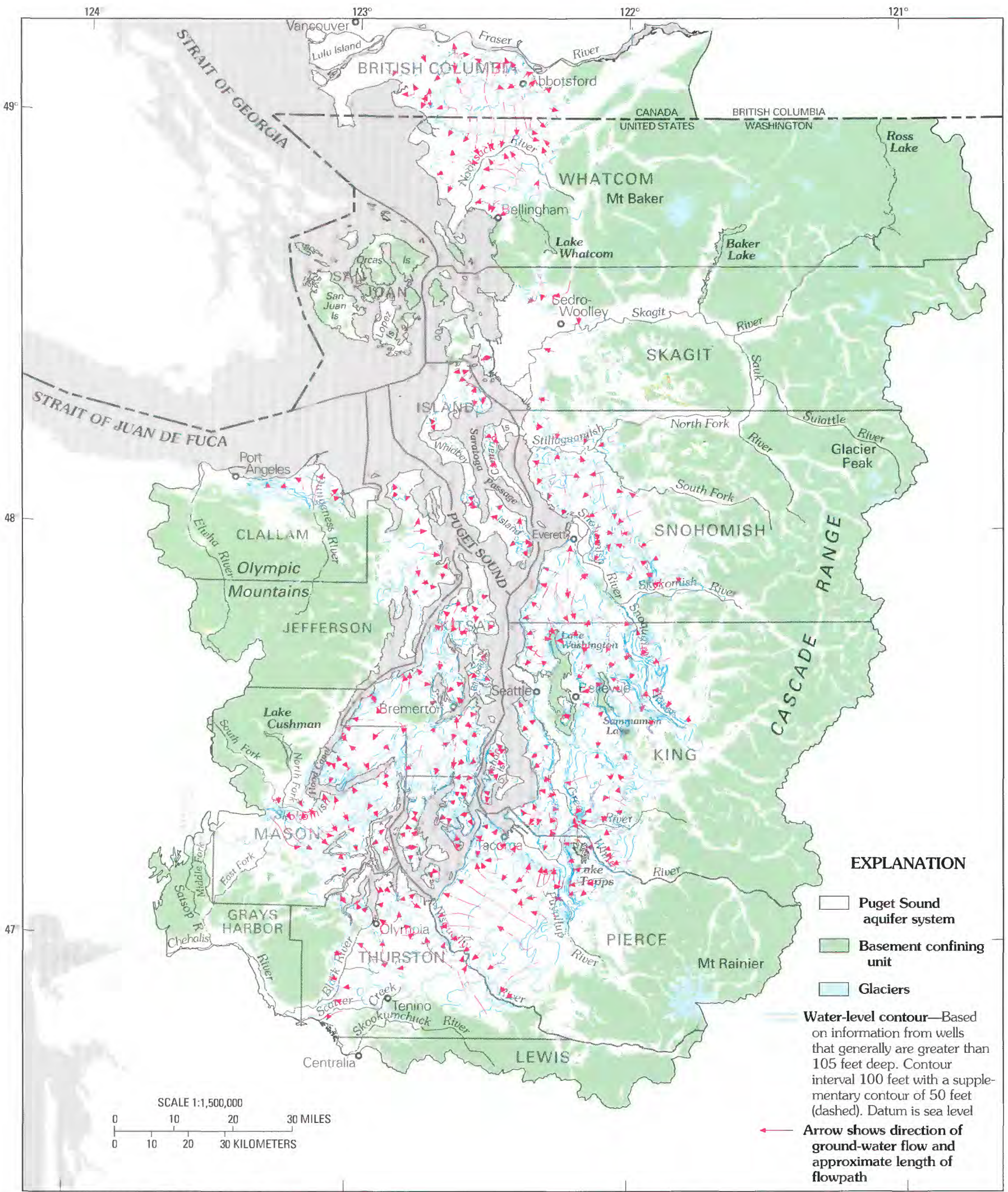

Base modified from U.S. Geological Survey

digital data, 1:2,000,000, 1972

FIGURE 10.-Generalized pattern of ground-water movement for the Puget Sound aquifer system. Lateral hydraulic gradients are indicated by spacing of generalized water-level contours. 
the Skagit, Green, and Puyallup River Valleys in figure 10. This is attributable to (1) coarse-grained materials along the rivers that have good hydraulic connection with the rivers and (2) the relatively flat topography of the top of the alluvium. Although some glacial deposits are as permeable as the alluvium, the discontinuous nature of the glacial-interglacial aquifer units and topographic control results in steeper gradients.

The vertical head gradients, estimated from well data (depth and water level) used to construct the generalized water-level configuration maps, range from about 0.005 to $1.6 \mathrm{ft} / \mathrm{ft}$ and appear to average about $0.3 \mathrm{ft} / \mathrm{ft}$. Gradients generally are downward (decreasing water levels with depth) over much of the area and upward (increasing water levels with depth) near saltwater bodies and major streams. The steeper gradients occur near bluffs in the steep upland areas, and in places where aquifer units are separated by clay-rich nonaquifer units comprised of interglacial or finegrained glaciomarine drift deposits. The estimated vertical-head differences, which were used to calculate the vertical gradients, ranged from about 1 to $200 \mathrm{ft}$.

The preceding simplified analysis indicates that (1) aspects of ground-water flow generally can be described by the segregation and subsequent mapping of water-level information based on well depth and land-surface altitude and (2) a simplified conceptual model probably can preserve the important regional characteristics of the aquifer system for describing ground-water flow in the region. Additionally, to improve understanding of the flow system and to address ground-water availability, the geologic framework needs to be accounted for by the mapping of regional hydrogeologic units. The conceptual model presented later in this report and the geologic framework of Jones (in press) provide the basis for future mapping of these regional units.

\section{HYDRAULIC CHARACTERISTICS}

The hydraulic and geometric characteristics that are most important for describing ground-water flow and for dividing or aggregating hydrogeologic units are hydraulic conductivity and transmissivity of aquifer units (product of horizontal hydraulic conductivity and aquifer thickness). The vertical hydraulic conductivity of confining and semiconfining units comprised of clayrich materials and glacial till also is important for describing the quantity of water that can flow into and between aquifers. Additionally, although not strictly a hydraulic characteristic, the specific capacity is an important characteristic for identifying the productivity of an aquifer.

\section{HYDRAULIC CONDUCTIVTTY}

Table 3 summarizes estimates of horizontal hydraulic conductivity made in previous studies (references listed in table). The numerous depositional environments and large variety of source materials, and thus lithologic characteristics, have resulted in a wide range of conductivity values. However, the estimates of hydraulic conductivity for similar materials generally are consistent from study to study, especially with respect to the average or median values.

The units that consist principally of sand have average conductivity values of about 15 to $50 \mathrm{ft} / \mathrm{d}$. Coarsegrained equivalents (including gravel facies) of some units average about $100 \mathrm{ft} / \mathrm{d}$. Zones within the deeper deposits (both divided and undivided) that appear to be predominantly sand have conductivities that range from 34 to $59 \mathrm{ft} / \mathrm{d}$ and average $41 \mathrm{ft} / \mathrm{d}$. Hydraulic conductivity values less than about $15 \mathrm{ft} / \mathrm{d}$ indicate a finegrained equivalent of the sand units (probably silty sand), and values less than about $10 \mathrm{ft} / \mathrm{d}$ indicate that the fine-grained equivalent contains more silt and probably has 1- to 10-percent clay content. The medium- to coarse-grained alluvium has conductivities that generally range from 35 to $700 \mathrm{ft} / \mathrm{d}$; these values generally are larger than the values for the glacial and proglacial materials. The conductivity of coarse-grained alluvium ranges from about 100 to $700 \mathrm{ft} / \mathrm{d}$, although, when the value for the Elwha River is not included, a value of about $200 \mathrm{ft} / \mathrm{d}$ appears to be a reasonable estimate for the average conductivity of the coarse-grained alluvium. The conductivity of fine-grained alluvium probably ranges from about 1 to $15 \mathrm{ft} / \mathrm{d}$. Fine-grained alluvium is typically fine sand intermixed with silt and clay; unless a sequence is predominantly clay or siltclay, a fine-sand description in drillers' logs can vary from nearly uniform homogenous fine sand to a mixture of silt and clay. This fine-grained alluvium typically is present in the lower reaches of the major river valleys.

The preceding information indicates that the aquifer units, in particular the more productive parts, generally have median conductivities in the range of 15 to $50 \mathrm{ft} / \mathrm{d}$. Larger values (50 to $200 \mathrm{ft} / \mathrm{d}$ ) indicate either coarsegrained (gravel) equivalents of glacial deposits or alluvial deposits. Values less than about $10 \mathrm{ft} / \mathrm{d}$ indicate fine-grained materials (either glacial, interglacial, or alluvial).

The glacial till in the study area consists of an unsorted, unstratified matrix of sand, silt, and clay with clasts of gravel, cobble, and boulders; gravel is the dominant coarse-grained material. The grain-size distribution of the till matrices averages about 55-percent sand, 28-percent silt, and 17-percent clay (Dethier and others, 
TABLE 3. Summary of published estimates of horizontal hydraulic conductivity

$[-$, indicates no data $]$

\begin{tabular}{|c|c|c|c|c|}
\hline Sediment type or stratigraphic unit ${ }^{1}$ & Reference $^{2}$ & $\begin{array}{l}\text { Number of } \\
\text { values }\end{array}$ & $\begin{array}{l}\text { Range (feet per } \\
\text { day) }\end{array}$ & $\begin{array}{c}\text { Geometric mean (G), } \\
\text { average }(\mathrm{A}), \text { or } \\
\text { median (M) } \\
\text { (feet per day) }\end{array}$ \\
\hline \multirow[t]{2}{*}{$\overline{\text { Advance outwash }}$} & $\mathbf{E}$ & 68 & $0.1-2,990$ & $33(\mathrm{M})$ \\
\hline & $\mathbf{H}$ & 73 & $3.2-6,970$ & $47(\mathrm{M})$ \\
\hline $\begin{array}{l}\text { Advance outwash (fine sand, } \\
\text { silt) }^{3}\end{array}$ & G & 37 & $0.02-16.7$ & $2.33(\mathrm{~A})$ \\
\hline $\begin{array}{l}\text { Advance outwash and Colvos } \\
\text { Sand (coarse grained) }\end{array}$ & $\mathbf{E}$ & 6 & $127-298$ & $174(\mathrm{M})$ \\
\hline Alluvium, Dungeness River & $\mathbf{P}$ & 62 & - & $410(\mathrm{M})$ \\
\hline $\begin{array}{l}\text { Alluvium, Elwha River (coarse } \\
\text { deposits) }\end{array}$ & $\mathbf{Q}$ & - & & $700(A)$ \\
\hline Alluvium, Green River & $\mathrm{N}$ & 18 & - & $100(\mathrm{~A})$ \\
\hline Alluvium, Green-Cedar River & $\mathbf{E}$ & 51 & $20-7,570$ & $290(\mathrm{M})$ \\
\hline $\begin{array}{l}\text { Alluvium, Green-White River } \\
\text { (fine to medium grained) }\end{array}$ & 0 & 10 & $1-100$ & $7.5(\mathrm{M})$ \\
\hline Alluvium, Nisqually River & $\mathbf{R}$ & - & $8.5-170$ & -- \\
\hline Coarse grained & $\mathbf{R}$ & - & - & $170(\mathrm{~A})$ \\
\hline Medium grained & $\mathbf{R}$ & - & - & $85(\mathrm{~A})$ \\
\hline Fine grained & $\mathbf{R}$ & - & - & $8.5(\mathrm{~A})$ \\
\hline Alluvium, Puyallup River & M & 42 & $85-475$ & $475(\mathrm{M})$ \\
\hline \multicolumn{5}{|l|}{$\begin{array}{l}\text { Alluvium, undivided glacial and } \\
\text { imterglacial }\end{array}$} \\
\hline Coarse grained & $\mathbf{P}$ & 121 & $140-170$ & $170(\mathrm{M})$ \\
\hline Medium grained & $\mathbf{P}$ & 93 & $22-52$ & $35(\mathrm{M})$ \\
\hline Fine grained & $\mathbf{P}$ & 150 & 2-15 & $8(\mathrm{M})$ \\
\hline $\begin{array}{l}\text { Alluvium and recessional } \\
\text { outwash }\end{array}$ & H & 15 & $6.2-915$ & $36(\mathrm{M})$ \\
\hline \multirow[t]{8}{*}{ Colvos Sand } & A & - & - & $5.0(\mathrm{~A})^{5}$ \\
\hline & A & - & - & $20(A)^{5}$ \\
\hline & A & - & - & $33(\mathrm{~A})^{5}$ \\
\hline & A & - & - & $33(\mathrm{~A})^{5}$ \\
\hline & A & -- & - & $88(A)^{5}$ \\
\hline & A & - & - & $100(\mathrm{~A})^{5}$ \\
\hline & B & 17 & $5-25$ & $10(\mathrm{G})$ \\
\hline & $\mathrm{C}$ & 15 & $1.1-1,160.0$ & $41(\mathrm{M})$ \\
\hline Colvos Sand (coarse grained) & $\mathbf{E}$ & 74 & $1.1-5,174$ & $51(\mathrm{M})$ \\
\hline Double Bluff Drift (sand only) & $\mathrm{D}$ & 20 & $3.2-501$ & $42(\mathrm{M})$ \\
\hline $\begin{array}{l}\text { Glacial and interglacial, } \\
\text { undivided }^{6}\end{array}$ & $\mathbf{M}$ & 41 & $43.0-320.0$ & $121(\mathrm{M})$ \\
\hline \multirow[t]{2}{*}{ Gravel } & $\mathrm{C}$ & 4 & $13-1,160$ & $800(\mathrm{M})$ \\
\hline & $\mathbf{H}$ & 22 & $3.7-915$ & $50(\mathrm{M})$ \\
\hline Interglacial silty clay & I & 3 & $0.00007-0.0029$ & $.0014(\mathrm{~A}, \mathrm{M})$ \\
\hline
\end{tabular}


TABLE 3. Summary of published estimates of horizontal hydraulic conductivity—Continued

\begin{tabular}{|c|c|c|c|c|}
\hline Sediment type or stratigraphic unit 1 & Reference $^{2}$ & $\begin{array}{l}\text { Number of } \\
\text { values }\end{array}$ & $\begin{array}{c}\text { Range (feet per } \\
\text { day) }\end{array}$ & $\begin{array}{c}\text { Geometric mean }(\mathrm{G}), \\
\text { average }(\mathrm{A}) \text {, or } \\
\text { median }(\mathrm{M}) \\
\text { (feet per day) }\end{array}$ \\
\hline $\begin{array}{l}\text { Kitsap Formation with coarse } \\
\text { lens }\end{array}$ & $\mathbf{C}$ & 34 & $1.5-310$ & $26(\mathrm{M})$ \\
\hline Quadra Formation (sand only) & $\mathrm{D}$ & 37 & $4.5-6,998$ & $81(\mathrm{M})$ \\
\hline Recessional outwash channel & $\mathbf{M}$ & - & - & $242(\mathrm{M})$ \\
\hline Salmon Springs Drift & $\mathrm{C}$ & 67 & $0.54-180$ & $14(\mathrm{M})$ \\
\hline $\begin{array}{l}\text { Salmon Springs Drift, } \\
\text { (penultimate drift) }\end{array}$ & $\mathbf{H}$ & 77 & $2.5-5,260$ & $59.0(\mathrm{M})$ \\
\hline $\begin{array}{l}\text { Salmon Springs Drift and } \\
\text { undivided deep deposits }\end{array}$ & $\mathrm{E}$ & 19 & $6-201$ & $41(\mathrm{M})$ \\
\hline $\begin{array}{l}\text { Salmon Springs Drift and } \\
\text { undivided deep sands }\end{array}$ & $\mathbf{F}$ & 20 & $40-450$ & $280(\mathrm{~A})$ \\
\hline \multirow[t]{2}{*}{ Sand } & $\mathrm{C}$ & 49 & $.54-150$ & $15(\mathrm{M})$ \\
\hline & $\mathbf{H}$ & 54 & $2.5-4,350$ & $30(\mathrm{M})$ \\
\hline Sand, fine & $\mathrm{C}$ & 37 & $0.4-45$ & $4.2(\mathrm{M})$ \\
\hline \multirow[t]{3}{*}{ Sand and gravel } & $\mathrm{C}$ & 52 & $3.6-310$ & $38(\mathrm{M})$ \\
\hline & $\mathrm{D}$ & 3 & $432-3,888$ & $49(\mathrm{M})$ \\
\hline & $\mathrm{H}$ & 166 & $2.9-6,970$ & $59(\mathrm{M})$ \\
\hline Sand and gravel, undivided deep & $\mathrm{D}$ & 2 & 8.3-207 & $41(\mathrm{G})$ \\
\hline \multirow[t]{4}{*}{ Till } & G & - & $0.003-0.08$ & - \\
\hline & $\mathbf{J}$ & - & $0.0003-14.2$ & - \\
\hline & $\mathbf{K}$ & - & $0.0003-0.03$ & $.014(\mathrm{~A})$ \\
\hline & $\mathrm{L}$ & - & $0.1-0.13$ & $.12(\mathrm{~A})$ \\
\hline Undivided, deep & $\mathbf{H}$ & 50 & $3.7-2,680$ & $34(\mathrm{M})$ \\
\hline Whidbey Formation (sand only) & $\mathrm{D}$ & 134 & $1.5-2,160$ & $134(\mathrm{M})$ \\
\hline \multicolumn{5}{|c|}{$\begin{array}{l}1_{\text {Stratigraphic units shown in figure } 5 .} \\
2 \text { A, Hansen and Bolke (1980); B, Tracy and Dion (1976); C, Dion and others (1988); D, Sapik and others (1988); } \\
\text { E, Woodward and others (1995); F, Seattle Water Department (1986); G, URS Consultants, Inc. (1992); H, G.L. } \\
\text { Turney, (U.S. Geological Survey, written commun., 1994); I, METRO (1983); J, Miller and Pessl (1986); K, Olmstead } \\
\text { (1969); L, Dion and others (1983); M, R.C. Lane, (U.S. Geological Survey, written commun., 1993); N, Lum and others } \\
\text { (1984); O, Hart Crowser and Associates (1984); P, Drost (1983a); Q, Walters and others (1979); R, Lum (1984). } \\
3_{37} \text { slug tests of } 9 \text { wells. }{ }^{4} \text { Presented as ranges; average of the } 10 \text { averaged ranges. }{ }^{5} \text { Average values are for different } \\
\text { areas. }\end{array}$} \\
\hline
\end{tabular}

1981; Vanderwal, 1985). Although the degree of consolidation of the till varies, it is usually highly consolidated. The hydraulic conductivity of till generally is smaller than both the glacial outwash, proglacial, and alluvial deposits and larger than the fine-grained interglacial deposits (table 3 ). However, little information is available on the hydraulic conductivity of the till. Because of this fact, field tests using a permeameter to estimate vertical hydraulic conductivity of the till in selected areas were conducted during this study. Values obtained by this method are not strictly representative of vertical conductivities but include horizontal 
components. Representative vertical values would be smaller than the values described in the following table. Results of the field tests showed the following attributes:

\begin{tabular}{llc}
\hline $\begin{array}{l}\text { Number } \\
\text { of } \\
\text { values }\end{array}$ & $\begin{array}{l}\text { Range } \\
\text { (feet per day) }\end{array}$ & $\begin{array}{l}\text { Median } \\
\text { (feet per day) }\end{array}$ \\
\hline 57 & $0.0002-53.0$ & 0.12 \\
\hline
\end{tabular}

The range indicates the variability of the till; however, the middle 80 percent of the values were in the range of about 0.005 to $22 \mathrm{ft} / \mathrm{d}$.

The grain-size characteristics of the till matrix in the Puget Sound Lowland (Dethier and others, 1981; Vanderwal, 1985, figs. 4 and 16) are similar to those in southern New England (Melvin and others, 1992, fig. 4), and the consolidation and stoniness of the two tills also appear to be similar. Thus, information on hydraulic conductivity for southern New England probably can be used as an analog for the conductivity of till in the Puget Sound Lowland. For more than 250 reported values of till conductivity for southern New England (Melvin and others, 1992), the range was 0.00023 to $96 \mathrm{ft} / \mathrm{d}$, and the median was about $0.3 \mathrm{ft} / \mathrm{d}$. The middle 80 percent were in the range 0.01 to $5.95 \mathrm{ft} / \mathrm{d}$, similar to the range obtained from the permeameter tests. Additionally, the smallest and largest 20 percent of these values were in the range 0.00023 to $0.03 \mathrm{ft} / \mathrm{d}$ and 3.97 to $96 \mathrm{ft} / \mathrm{d}$, respectively, showing that the middle 60 percent (range, 0.03 to $3.97 \mathrm{ft} / \mathrm{d}$ ) is essentially the same as the 80-percent range. Based on the assumptions that the median is a good estimate for a regional value and a vertical conductivity value would be conservatively one to two orders of magnitude smaller than a horizontal value, the preceding information suggests that the regional effective vertical hydraulic conductivity of the till in the study area is in the range 0.001 to

$0.01 \mathrm{ft} / \mathrm{d}$. This range is less than the upper limit of values presented in table 3 and near the lower quartile of the permeameter-derived values and the New England values.

Most interglacial deposits consist of well-bedded, clay-rich units that are not productive aquifers. However, these interglacial deposits may consist of sand to clay with some beds of sand and gravel and may locally contain peat. Some of the interglacial deposits appear to become more coarse grained and have more lenses of sand and gravel at the periphery of the aquifer system. For example, the interglacial deposits present along the Strait of Juan de Fuca in parts of Clallam County generally are coarse grained (Washington Department of Ecol- ogy, 1978); the close proximity to the source of the deposits, the Olympic Mountains, can account for the coarseness of these deposits.

The conductivities of the fine-grained interglacial deposits probably are on the order of 0.00001 to $1.0 \mathrm{ft} / \mathrm{d}$ (Freeze and Cherry, 1979, and table 3). Investigations of the fine-grained (clayey) till in the Interior Plains of North America (Grisak and Cherry, 1975; Grisak and others, 1976; Keller and others, 1989) show vertical conductivity to range from about 0.000003 to $0.003 \mathrm{ft} / \mathrm{d}$ and average about $0.0001 \mathrm{ft} / \mathrm{d}$. These investigations suggest that the clayey till is a good model for compacted lacustrine sediments. The clayey till is similar to the finegrained interglacial deposits, suggesting that the vertical conductivity of the fine-grained deposits is on the order of $0.0001 \mathrm{ft} / \mathrm{d}$. This value is about one order of magnitude smaller than the average value and one order of magnitude larger than the smallest estimated by METRO (1983) for interglacial sediments (table 3).

Although the hydraulic conductivity varies locally, on a regional basis the hydraulic conductivity of hydrologic units can be characterized by average and median values. Further, excluding till, grain size appears to be a reasonable indicator for estimating average conductivity values and for describing hydrogeologic sequences or units. The known relations between grain size and hydraulic conductivity have been used in many investigations, for example, Gutentag and others (1984). Till appears to have much smaller conductivities than most glacial, proglacial, and alluvial deposits but much larger conductivities than the fine-grained interglacial deposits. The small conductivities of most interglacial deposits indicate that they can be considered semiconfining to confining units for the conceptual model of ground-water flow.

Additionally, analyses of ground-water flow systems in areas where the Everson "glaciomarine" Drift exists indicate that the fine-grained part of this unit has hydraulic conductivities that are similar to both the till and the interglacial deposits (Sapik and others, 1988; S. Cox, U.S. Geological Survey, written commun., 1993). This drift was deposited during the Everson Interstade and is present in (1) the Fraser-Whatcom Basin (fig. 6), where it generally is fine-grained, and in (2) the northcentral Puget Sound Lowland, where it varies from fine to medium grained. Available information suggests that this drift generally functions as a confining unit in the Fraser-Whatcom Basin and as a semiconfining unit in the remainder of the area where it is present. Outside of the Fraser-Whatcom Basin, its range in conductivity is probably similar to till, and thus the conductivity of the drift is estimated to range from 0.001 to $0.1 \mathrm{ft} / \mathrm{d}$. 


\section{TRANSMISSIVITY}

Reported transmissivity values for the aquifers in the Puget Sound Lowland range from 5 to $3,010,000 \mathrm{ft}^{2} / \mathrm{d}$ (Cline, 1969; Hansen and Bolke, 1980; Drost, 1982; Brown and Caldwell, 1985; Carr and Associates, 1983, 1988; Hart Crowser and Associates, 1986, $1988 \mathrm{a}, \mathrm{b}, 1989 \mathrm{a}, \mathrm{b})$. Values greater than about $2,000 \mathrm{ft}^{2} / \mathrm{d}$ generally are for thick, coarse-grained deposits located in alluvial valleys; well-defined massive recessional outwash channels; or deep, below-sea-level aquifer units. On a regional basis, reported transmissivity values generally range from 50 to $2,000 \mathrm{ft}^{2} / \mathrm{d}$ and average about $500 \mathrm{ft}^{2} / \mathrm{d}$.

To better understand the range in transmissivity values for the Puget Sound Lowland, all specific-capacity information in NWIS was used to calculate transmissivity values by the method of Theis (1963). There were 5,502 data points with the following attributes:

\begin{tabular}{lcccc}
\hline Attribute & Average & Median & $\begin{array}{l}10 \text { th } \\
\text { decile }\end{array}$ & $\begin{array}{l}\text { 90th } \\
\text { decile }\end{array}$ \\
\hline $\begin{array}{l}\text { Discharge } \\
\text { (gallon per }\end{array}$ & 94 & 20 & 8 & 215 \\
$\begin{array}{c}\text { minute) } \\
\text { Well depth (feet) }\end{array}$ & 153 & 120 & 38 & 300 \\
\hline
\end{tabular}

Calculated transmissivity values ranged from 1 to $764,000 \mathrm{ft}^{2} / \mathrm{d}$ and averaged $2,890 \mathrm{ft}^{2} / \mathrm{d}$. However, the $10-, 50-$, and 90-decile values were 38,430 , and $4,460 \mathrm{ft}^{2} / \mathrm{d}$, respectively.

\section{SPECIFIC CAPACITY}

The specific-capacity information, which also characterizes the hydraulic conductivity, was analyzed for (1) descriptive statistics by calculating statistics of the available data and (2) spatial trends by plotting the values on a map. The specific-capacity values ranged from 0.004 to $1,135(\mathrm{gal} / \mathrm{min}) / \mathrm{ft}$ and averaged $11(\mathrm{gal} / \mathrm{min}) / \mathrm{ft}$, with a median of $2(\mathrm{gal} / \mathrm{min}) / \mathrm{ft}$. The 10- and 90-decile values are 0.25 and $22(\mathrm{gal} / \mathrm{min}) / \mathrm{ft}$, respectively. As described previously, of 1,099 wells that were less than $50 \mathrm{ft}$ deep, the median yield was $30 \mathrm{gal} / \mathrm{min}$, which is $10 \mathrm{gal} / \mathrm{min}$ larger than the median for all wells. The larger yield suggests that the upper part of the aquifer system may be more productive than the system on average, probably because of the productive, shallow wells located in the alluvium and the recessional outwash channels. Analysis of 837 of the 1,099 wells that had specific-capacity values showed values that ranged from 0.04 to $818(\mathrm{gal} / \mathrm{min}) / \mathrm{ft}$ and averaged $24(\mathrm{gal} / \mathrm{min}) / \mathrm{ft}$ [median of $(8 \mathrm{gal} / \mathrm{min}) / \mathrm{ft}$ ], the latter two values are larger than the system on average. Also note that these values do not appear to be largely affected by well discharge because the correlation coefficient between well diameter and specific capacity was only 0.21 .

The mapped distribution of specific capacity displays some spatial trends. These trends indicate the following well-defined areas of larger-than-average specific-capacity values: (1) the large alluvial river valleys (for example, the Skagit, Green, and Puyallup River Valleys), (2) the areas with larger extents of recessional outwash, and (3) the Fraser-Whatcom Basin (fig. 6). These trends indicate the potential for aggregating units in the Puget Sound Lowland. For example, the trends indicate that, on the basis of hydraulic characteristics, alluvial deposits within the large river valleys should be separated into a distinct hydrogeologic unit and that the alluvial deposits probably compose large separate aquifer units in these valleys. Drillers' logs indicate this unit exceeds $600 \mathrm{ft}$ in thickness in the Puyallup River Valley (Noble, 1990) and $400 \mathrm{ft}$ in the Green River Valley (Woodward and others, 1995).

\section{REGHARGE}

Ground-water recharge is perhaps the most important control on ground-water availability. An understanding of the range in recharge and the controls on recharge is important for describing the groundwater flow. The controls on recharge include physical characteristics-topography, soil characteristics, land use and cover, and surficial geology-and water-budget components at or near the land surface-actual evapotranspiration (AET), surface and subsurface runoff, and precipitation. Together, the physical characteristics and water-budget components, including recharge, uniquely define the surface hydrology and are important for describing the hydrology of the area. Therefore, a brief background covering recharge estimates and methods used to derive recharge estimates from previous investigations is first presented. Limitations in these methods also are discussed. Previous estimates based on the use of daily climate information are summarized, and information relating to physical characteristics, water-budget components, and relations to recharge are then discussed. The estimates for mean annual recharge, including the method used and its limitations, to the Puget Sound aquifer system are described next. Last, the reliability of the estimates is discussed. 


\section{BAGKGROUND}

The most commonly used methods to estimate recharge in the Puget Sound Lowland have been the monthly water-balance methods of Blaney-Criddle (U.S. Department of Agriculture, 1970) and Thornthwaite (Thornthwaite, 1948; Thornthwaite and others, 1957). Examples of the use of these methods in the Puget Sound Lowland are found in Noble and Wallace (1966), Richardson and others (1968), Eddy (1975), Drost (1979a,b), Grimstad and Carson (1981), Drost (1982), Carr and Associates (1983), and Brown and Caldwell (1985). These methods generally are based on long-term average values of precipitation, temperature, potential evapotranspiration (PET), and AET. Potential ET, AET, precipitation, and an assumed soil water-storage capacity provide an estimate of the quantity of water available-the surplus - for either ground-water recharge or surface runoff. Estimates are then made of runoff, and the quantity of recharge is calculated as the residual of the surplus. Generally, the water surplus has been used to define the maximum potential recharge that could occur. The results of these methods are sensitive to the soil water-storage capacity, the time-period of record chosen for the analysis, and the estimation of runoff.

An important limitation on the use of these methods is the period of record that is used. That is, the variability of the recharge estimate is much smaller than the variability of natural recharge because most estimates are derived using averaged climate data, not annual or monthly climate data, which display large variability. For example, the water-year precipitation at three selected weather stations in Washington in the Puget Sound Lowland shows the following attributes:

\begin{tabular}{lccc}
\hline Location & $\begin{array}{c}\text { Average } \\
\text { (inch per year) }\end{array}$ & $\begin{array}{c}\text { Range } \\
\text { (inch per year) }\end{array}$ & $\begin{array}{c}\text { Range } \\
\text { difference } \\
\text { (inch per year) }\end{array}$ \\
\hline Port Townsend & 19 & $11-35$ & 24 \\
Orcas Island & 29 & $16-40$ & 24 \\
Olympia & 53 & $31-80$ & 49
\end{tabular}

These attributes indicate the large variability in precipitation (the range difference is similar to the average) in the low-lying part of the Puget Sound Lowland. The interannual variability in precipitation and, thus, in recharge is important because of (1) the numerous shallow water-table wells in the Puget Sound Lowland, which are more sensitive to short-term recharge variations, and (2) the need to understand the natural variability of recharge for long-term assessment of groundwater availability. The monthly methods may be more useful if several years of monthly data are used to calculate potential ranges in the water surplus to derive improved estimates of recharge, including its potential variability; the potential variability in recharge is discussed at the end of this section. However, even in humid climates, using monthly climate data can result in inaccurate estimates of recharge (Giambelluca and Oki, 1987).

Using several years of daily climate data can provide more reliable estimates of mean recharge than can the monthly data. The use of daily water-budgeting methods to estimate recharge for large areas for ground-water investigations is relatively new. The earliest known use in the Puget Sound Lowland was in a ground-water study of Island County (Sapik and others, 1988). This investigation used a daily energy-soil-water budget model (H. Bauer, U.S. Geological Survey, oral commun., 1992) that was an early precursor to a deep percolation model (DPM) developed and documented by Bauer and Vaccaro (1987). The DPM calculates, as a residual, the quantity of water percolating below the active root zone (deep percolation) for any number of model cells that an area is divided into. The calculated deep percolation is assumed to be ground-water recharge. Observed streamflow minus the groundwater contribution (base flow) is used as an input into DPM. The DPM was applied to eight basins in southwest King County (Woodward and others, in press) and to two areas located within the lower Puyallup River Basin (R.C. Lane, U.S. Geological Survey, written commun., 1992).

A second daily water-budgeting method that has been used in the Puget Sound Lowland to indirectly calculate ground-water recharge is the Hydrological Simulation Program-FORTRAN (HSPF) watershed model (U.S. Environmental Protection Agency, 1984). Dinicola (1990) applied the HSPF and model-derived parameters to 33 low-altitude basins with drainage areas generally less that $20 \mathrm{mi}^{2}$ in King and Snohomish Counties. Berris (1995) and Mastin (1996) applied the model to three basins in Thurston County and three basins in Pierce County, respectively. The HSPF calculates the quantity of precipitation that becomes either subsurface runoff or recharge to the deeper ground-water reservoir. The latter is assumed to be equal to the quantity of deep percolation and the estimate of recharge. The HSPF also calculates base flow.

\section{PREVIOUS RESULTS AND RELATIONS BETWEEN WATER-BUDGET COMPONENTS}

The results from these previous studies that applied HSPF and DPM are summarized for 26 basins or areas. The results are shown in table 4 , and the location of the basins is shown in figure 11. For the 26 basins, the ranges in mean annual values were precipitation-25.17 


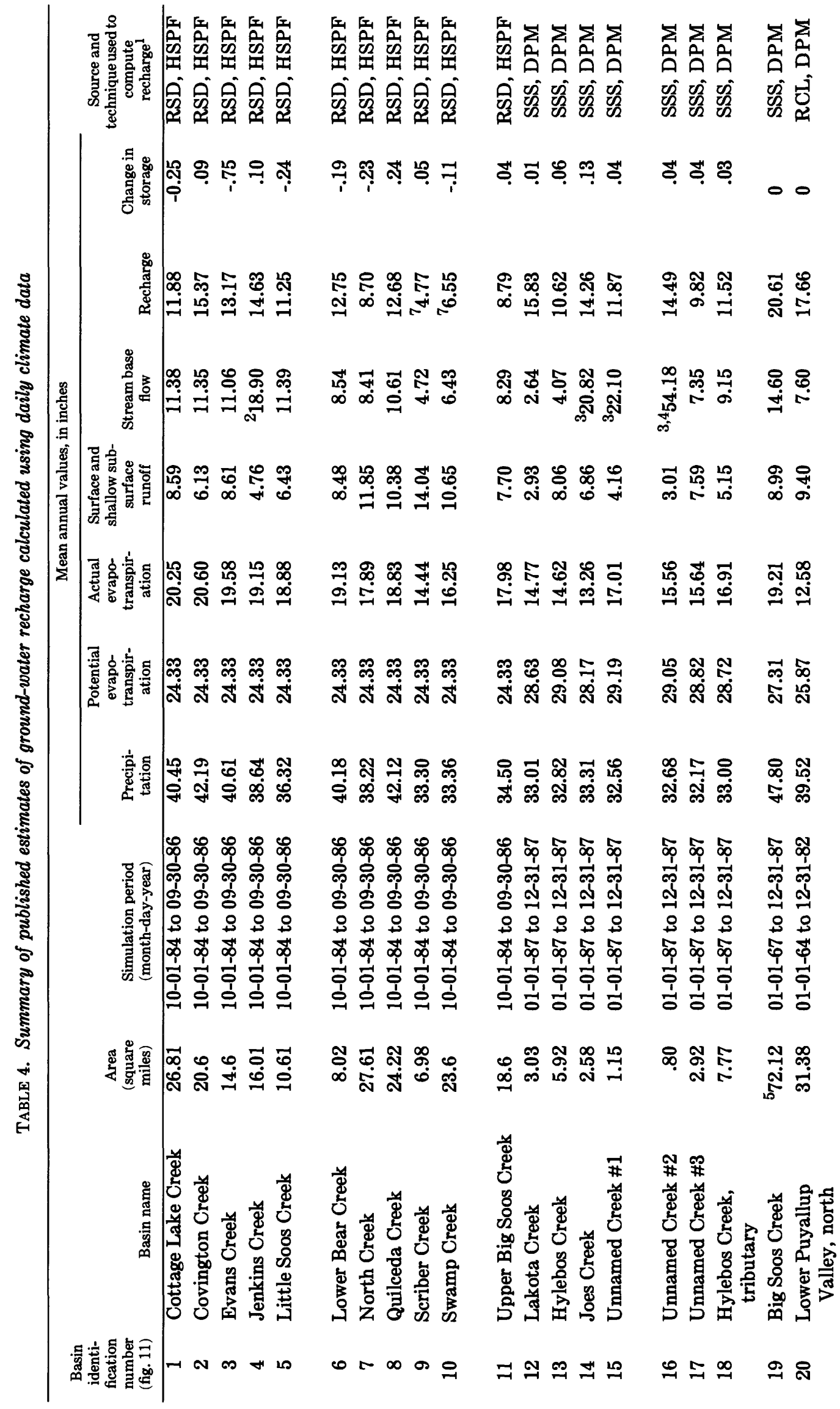




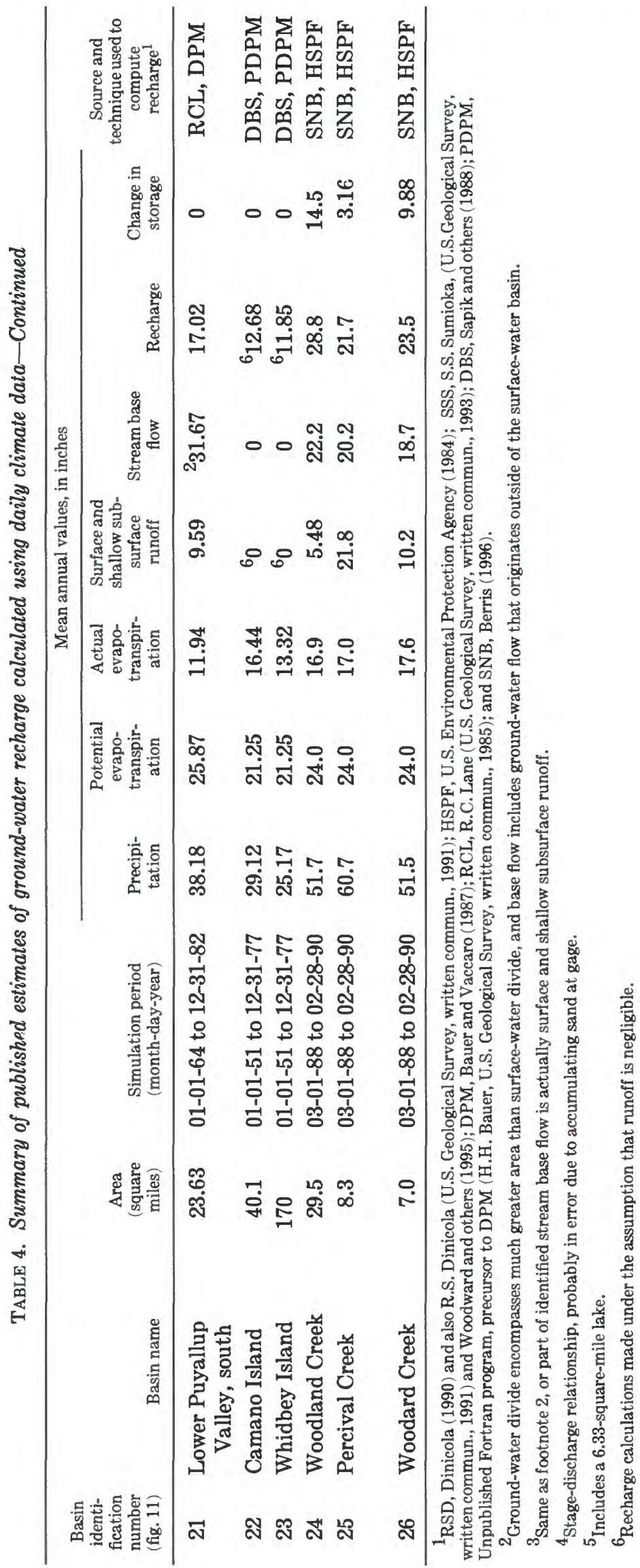




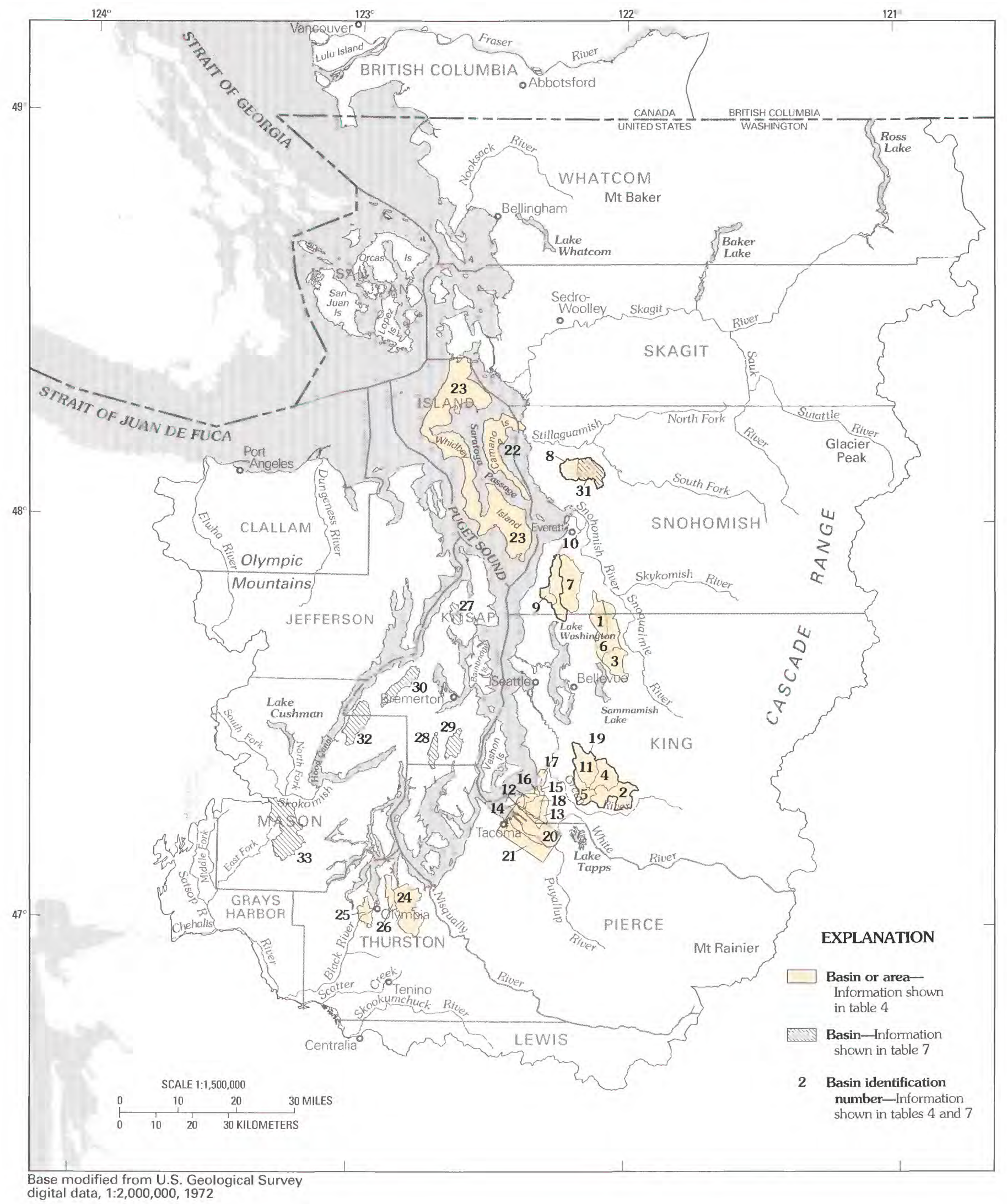

FIGURE 11.- Location of 26 basins or areas where recharge was estimated by investigators using daily climate data and 7 basins where recharge, estimated during this study, is compared to streamflow. 
to 60.7 in.; runoff -0 to 21.8 in.; AET-11.94 to 20.60 in.; base flow (excluding the largest values, see footnote table 4) -0 to 22.2 in.; and recharge -4.77 to 28.8 in. The large range in the estimates of ground-water recharge is due to the large range in the precipitation, AET, and runoff water-budget components. Additionally, three other factors affect the large range in values shown in table 4. (1) Streamflow for basins 4, 14, 15, 16, and 21 includes a ground-water component that originates from outside the basin; (2) streamflow was assumed to be zero for the analyses of basins 22 and 23; and (3) basins 9 and 10 have the largest fraction of impervious area.
The information presented in table 4 is summarized by descriptive statistics in table 5 ; correlation matrices and regression relations between water-budget components developed on the basis of the mean annual values (excluding base flow) of table 4 and annual values for basin 19 also are presented in table 5 . The statistical summary clearly shows the large ranges in values described. The correlation matrices show, as expected, that the strongest relation exists between precipitation and the other water-budget components. However, the expected relation between recharge and runoff is not stronger because some runoff values include water derived from outside of a basin, recharge does not

TABLE 5. Information and statistics on the relation between water-budget components

[Based on the annual water-budget components from basins in table 4; $R^{2}$, regression correlation coefficient squared]

\begin{tabular}{|c|c|c|c|c|c|c|c|}
\hline \multirow[b]{2}{*}{ Variable } & \multirow[b]{2}{*}{ Mean } & \multirow[b]{2}{*}{ Minimum } & \multirow[b]{2}{*}{ Maximum } & \multicolumn{3}{|c|}{ Percentiles } & \multirow{2}{*}{$\begin{array}{l}\text { Mean } \\
\text { percentage } \\
\text { of precipi- } \\
\text { tation }\end{array}$} \\
\hline & & & & $\begin{array}{c}\text { 20th } \\
\text { percentile }\end{array}$ & $\begin{array}{c}50 \text { th } \\
\text { percentile }\end{array}$ & $\begin{array}{c}\text { 80th } \\
\text { percentile }\end{array}$ & \\
\hline & \multicolumn{7}{|c|}{ Values, in inches per year } \\
\hline Precipitation (P) & 38.20 & 25.17 & 60.70 & 32.74 & 37.25 & 42.16 & - \\
\hline Recharge (R) & 13.95 & 4.77 & 28.80 & 10.14 & 12.71 & 17.40 & 37 \\
\hline Actual evapotranspiration (AET) & 16.76 & 11.94 & 20.60 & 14.51 & 16.95 & 19.14 & 44 \\
\hline Surface/subsurface runoff $(\mathrm{RO})^{1}$ & 7.72 & 0 & 21.80 & 4.40 & 7.88 & 10.31 & 20 \\
\hline Base flow (BSF) ${ }^{2}$ & 13.68 & 0 & 54.18 & 5.40 & 10.83 & 20.74 & 36 \\
\hline
\end{tabular}

\begin{tabular}{|c|c|c|c|c|c|c|c|c|c|c|c|}
\hline & \multicolumn{5}{|c|}{ Correlation matrix ${ }^{3}$} & & \multicolumn{5}{|c|}{ Correlation matrix ${ }^{4}$} \\
\hline & $\overline{\mathbf{R}}$ & $\overline{\mathbf{P}}$ & AET & RO & BSF & & $\overline{\mathbf{R}}$ & $\overline{\mathbf{P}}$ & AET & RO & BSF \\
\hline $\mathbf{R}$ & 100 & 74 & 3 & 7 & 39 & $\mathbf{R}$ & 100 & 77 & -11 & 21 & $\overline{31}$ \\
\hline $\mathbf{P}$ & 74 & 100 & 39 & 65 & 27 & $\mathbf{P}$ & 77 & 100 & 29 & 69 & 9 \\
\hline AET & 3 & 39 & 100 & 9 & -2 & AET & -11 & 29 & 100 & 4 & -17 \\
\hline RO & 7 & 65 & 9 & 100 & 1 & KO & 21 & 69 & 4 & 100 & -14 \\
\hline BSF & 39 & 27 & -2 & 1 & 100 & BSF & 31 & 9 & -17 & -14 & 100 \\
\hline
\end{tabular}

\begin{tabular}{|c|c|c|}
\hline Regression equations showing relation between water-budget components & $\begin{array}{c}\text { Equation } \\
\text { number }\end{array}$ & $\mathrm{R}^{2}$ \\
\hline $\mathrm{R}=0.98 \mathrm{P}-.99 \mathrm{RO}-1.00 \mathrm{AET}+1.00$ & (1) & 0.995 \\
\hline $\mathrm{R}=0.96 \mathrm{P}-.98 \mathrm{RO}-1.01 \mathrm{AET}+1.81$ & ${ }^{4}(2)$ & .995 \\
\hline$R=0.497 P-5.03(R=0$, when $P=10.12$ in. $) d$ & (3) & .540 \\
\hline$R=0.517 P-5.62(R=0$, when $P=10.88$ in. $)$ & $4(4)$ & .589 \\
\hline$R=0.542 P-6.06(R=0$, when $P=11.18$ in., till-covered areas $)$ & $5(5)$ & .727 \\
\hline$R=0.838 P-9.77(R=0$, when $P=11.66$ in., outwash-covered area $)$ & $5(6)$ & .921 \\
\hline
\end{tabular}

\footnotetext{
${ }^{1}$ Assumed zero for basins 22 and 23 (table 4), Actual values probably 5 to 10 percent of precipitation; recharge is a maximum estimate.

${ }^{2}$ Basins $4,14,15,16$, and 21 (table 4) include base flow from ground-water flow that originates outside of the basin.

${ }^{3}$ Correlation coefficients multiplied by 100 .

${ }^{4}$ Values for basins $9,10,22$, and 23 (table 4) not included in analysis.

${ }^{5}$ Relation based on 21 years of annual values for basin 19 (table 4 ).
} 
always discharge within a basin, and runoff was assumed to be zero for basins 22 and 23 .

Equations 1 and 2 (table 5) show the overall relation among water-budget components and were derived with recharge as the dependent variable; each component contributes to the explained variance in the calculated recharge values. For example, the percentage of the variance of recharge $(R)$ explained by precipitation $(P)$, surface and subsurface runoff (RO), and AET in equation 1 is 54,28 , and 18 percent, respectively. The dominant control on recharge is thus the quantity of precipitation. This is further shown by the relation between mean annual precipitation and recharge presented in figure 12. Therefore, two regression relations (equations 3 and 4, table 5) were initially developed using only precipitation as the independent variable; the first used all 26 mean annual values from table 4, and the second used 22 mean annual values. For equation 4 , basins $9,10,22$, and 23 in table 4 were not used; basins 9 and 10 would have smaller than average $R$ because of the large impervious area cover, and basins 22 and 23 would have larger than average $R$ because $\mathrm{RO}$ was assumed to be zero for these areas.

The scatter in the data in figure 12 is due to the variability in water-budget components other than precipitation, which, in turn, are affected by three physical factors: surficial geology (fine-grained deposits-mainly till, glaciomarine, and mudflow deposits-in contrast to coarse-grained deposits-mainly outwash and alluvial deposits), land use and cover (forest, pasture, residential, urban), and land-surface slope.
For watersheds with similar cover and slope, Dinicola (1990) found that the surficial geology was the primary control on the quantity of recharge. Soils generally are not a factor because most soils in the glaciated lowlands are highly permeable, with infiltration capacities exceeding most rainfall intensities. Thus, the underlying surficial geologic materials control the rate at which soil water can move downward. In areas underlain by fine-grained deposits, more water will move as subsurface flow to streams than in areas underlain by coarse-grained deposits; in the areas underlain by coarse-grained deposits, the soil water can more freely percolate downward to the water table. Therefore, after incident precipitation is abstracted by the ET processes, the dominant control on ground-water recharge becomes surficial geology.

Land use and cover control the quantity of AET, which affects the quantity of recharge. For example, Dinicola (1990) estimated that AET from forests is about 4 to 5 in. more than AET from grasses; that difference is about the same as that described in the literature (Pearce and others, 1980). Note that before development, most of the Puget Sound Lowland was covered by forests with highly permeable soils and a well-developed forest litter with a large water-retention capacity. For the grass-covered areas or areas cleared of forests, the additional water not used by AET is available for runoff or recharge-generally increased runoff in areas covered by fine-grained deposits or increased recharge in areas covered by coarse-grained deposits. Recharge and AET generally are zero for impervious areas, and

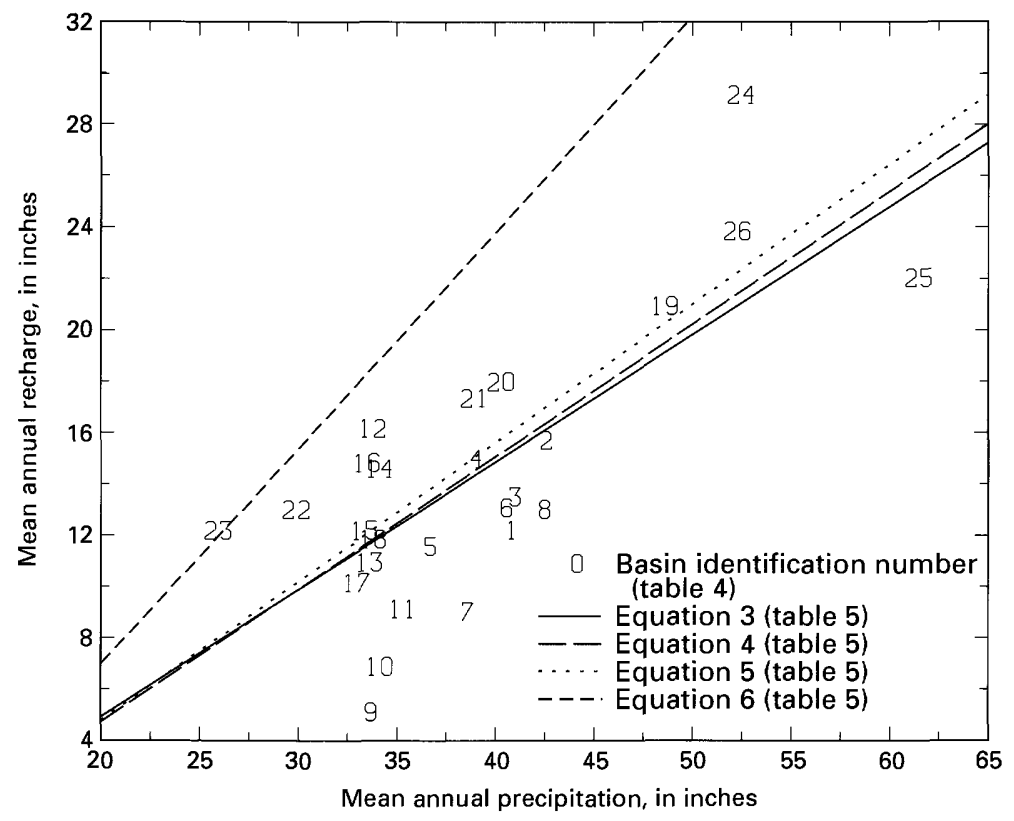

FIGURE 12.-Relations between mean annual precipitation and recharge for 26 basins or areas. 
the incident precipitation becomes runoff (see for example, basins 9 and 10 in table 4 , the two basins with the largest percentage of impervious area and plotted as the two lowest points in figure 12). In urban and industrial areas, most of the runoff is directed to drains and sewers, whereas in residential areas this runoff may be directed to manmade ditches, stormwater detention ponds, or small streams. For the latter case, some of the runoff may percolate downward to the water table. Additionally, recharge in residential areas may be altered by grading and subsequent importing of finegrained soil. A part of the permeable soils is removed, the remaining soils are graded and compacted, reducing the effective infiltration rate, and fine-grained top soil is applied. Together, these act to limit the potential recharge rates.

Land-surface slope affects the quantity of recharge by controlling the quantity of incident solar radiation that drives AET and by providing larger downslope gravitational control on the movement of soil water. Dinicola (1990) showed a decrease in AET for steep hillslopes, especially north-facing ones. Dinicola (1990) also showed that for the headwater basins investigated in King and Snohomish Counties, a large part of the available water in steep topography moved downslope as runoff to streams or to outwash-covered areas where it infiltrates.

\section{ESTIMATES OF MEAN ANNUAL RECHARGE}

Developing regional estimates of recharge is problematic because of the complex and highly variable controlling factors. However, the information presented in table 5 and figure 12 suggests that regional estimates of mean annual recharge can at least be approximated. Although equations 1 and 2 show that each water-budget component explains some of the variance in the estimated recharge, the AET and RO components generally are unknown for large areas. Thus, only the precipitation water-budget component can be used in regressions that are applied regionally.

Regional estimates of mean annual recharge then can be made using equation 3 or 4 . However, work completed in this study includes a compilation of surficial geology in terms of hydrogeologic units for the Puget Sound Lowland. This compilation allows for identification of areas covered by fine-grained or coarse-grained deposits (Jones, in press; see also fig. 6), and as described previously, the surficial geology is a dominant control on recharge. Because of the effect of surficial geology, S.S. Sumioka and R.S. Dinicola (U.S. Geological Survey, written commun., 1992) used the 21 annual values of precipitation and recharge for each of the DPM-cells for Big Soos Creek (basin 19, table 4) delineated by till and outwash to develop regression relations. The information for Big Soos Creek was used because of the longer period of model simulation. However, for the same mean annual precipitation, the resulting regression relations (equations 5 and 6, table 5) would estimate larger values of recharge than either equation 3 or 4 . Additionally, equation 4 may overestimate recharge for till-covered areas because slow drainage out of both the overlying soils and the till can easily be misidentified as base flow instead of subsurface runoff. For example, streamflow data were collected for more than 2 water years in three headwater basins located in the lowlands as part of an extensive fieldbased study to estimate recharge through till. These three basins are completely covered by till, and the streamflow-gaging sites were located above the water table in the till (H.H. Bauer, U.S. Geological Survey, written commun., 1994). H.H. Bauer (U.S. Geological Survey, written commun., 1994) showed that the streamflow hydrograph, which represents drainage out of the soil and till, is similar in shape to other hydrographs that include a contribution from ground water.

Considering the preceding information, preliminary estimates of recharge for the three headwater basins and the estimated range in the vertical hydraulic conductivity of the till described previously, the regression equation that estimated the least quantity of recharge for the range in mean annual precipitation for the aquifer system was selected to be applied to fine-grained deposits. Mean annual recharge to the aquifer system was thus estimated using equation 3 for areas underlain by till and other fine-grained deposits $\left(3,320 \mathrm{mi}^{2}\right)$ and equation 6 for areas underlain by outwash and other coarse-grained deposits $\left(3,863 \mathrm{mi}^{2}\right)$. The estimates are for all nonbedrock areas. The distribution of precipitation was based on the mean annual precipitation for 1930-57 for the State of Washington (U.S. Weather Bureau, 1965) and the mean annual precipitation for 1951-80 for the part of the aquifer system that underlies British Columbia, Canada (Environment Canada, n.d.). Next, to account for land use and cover, the estimates of recharge for urban-type areas (more than 90 percent of the surface covered by impermeable materials) were set to zero, recharge for built-up areas (about 95 percent of area covered) was reduced by 75 percent, and recharge for residential areas with large population densities (about 50 percent of area covered) was reduced by 50 percent. These areas were identified using digital land-use and cover data (U.S. Geological Survey, 1990). The resulting spatial distribution of the estimated mean annual recharge is shown in figure 13 , and the results of the analysis are given in table 6.

Several limitations should be noted concerning the derived estimates of recharge (table 6; fig. 13). First, recharge estimates for the mainly mountainous areas 


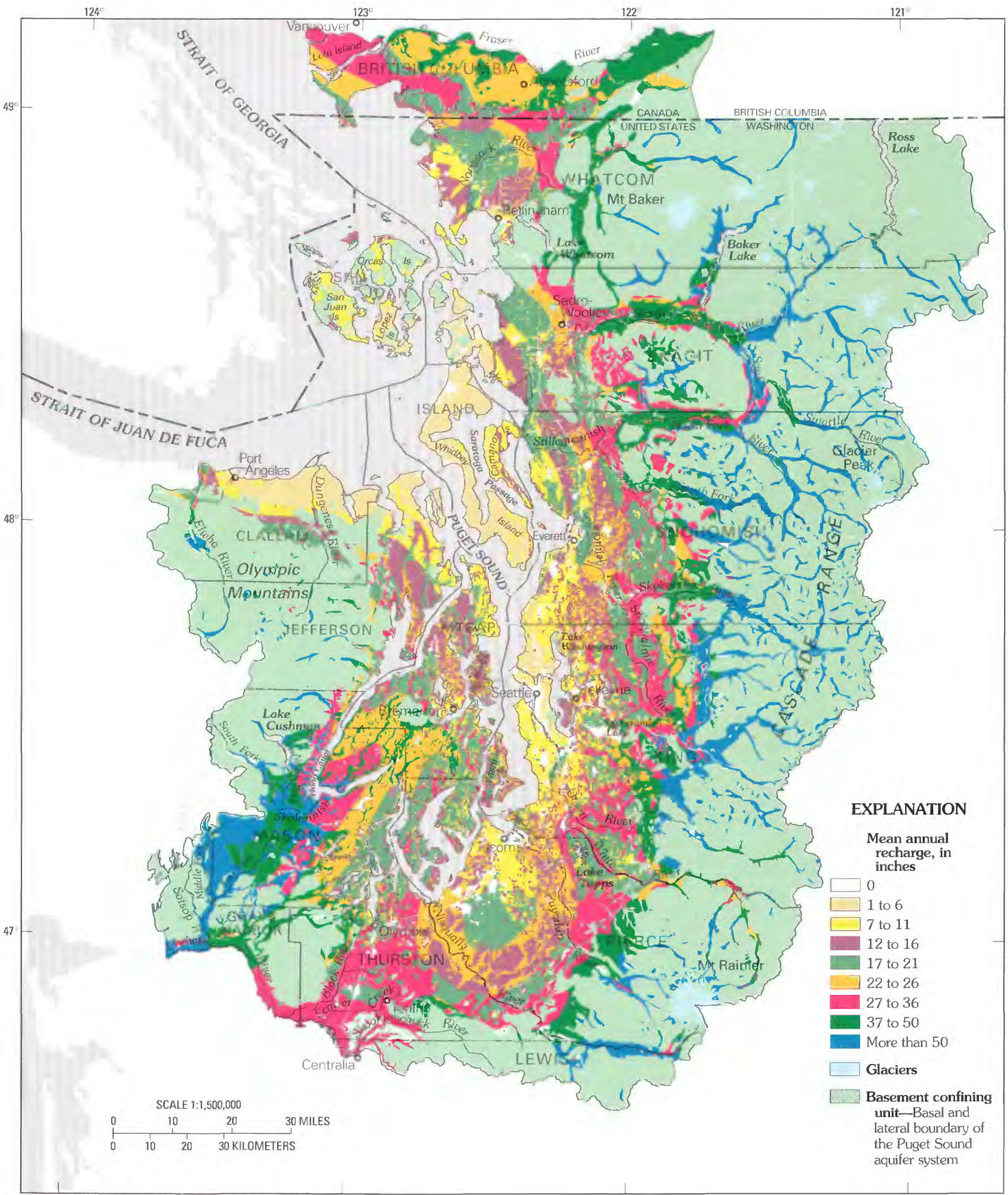

Base modified from U.S. Geological Survey

digital data, $1: 2,000,000,1972$

FIGURE 13.-Estimated distribution of mean annual ground-water recharge for the Puget Sound aquifer system. 
TABLE 6. Estimates of mean annual recharge on the basis of mean annual precipitation, generalized surficial geology, and land-use and cover categories

$\left[\mathrm{mi}^{2}\right.$, square miles; in/yr, inches per year, $\mathrm{ft}^{3} / \mathrm{s}$, cubic feet per second]

\begin{tabular}{|c|c|c|c|c|c|c|}
\hline Surficial geology & Land use and cover & $\begin{array}{l}\text { Area } \\
\left(\mathrm{mi}^{2}\right)\end{array}$ & $\begin{array}{c}\text { Recharge } \\
\text { (in/yr) }\end{array}$ & $\begin{array}{c}\text { Recharge }^{1} \\
\left(\mathrm{ft}^{3} / \mathrm{s}\right)\end{array}$ & $\begin{array}{l}\text { Precipitation } \\
\quad(\text { in/yr })\end{array}$ & $\begin{array}{c}\text { Precipitation } \\
\quad\left(\mathrm{ft}^{3} / \mathrm{s}\right)\end{array}$ \\
\hline \multirow[t]{5}{*}{ Fine-grained deposits } & Undeveloped and nonbuilt up & 2,709 & 20.0 & 3,999 & 50.5 & 10,066 \\
\hline & Residential & 51 & 10.5 & 40 & 38.4 & 144 \\
\hline & Built up & 471 & 7.4 & 255 & 40.0 & 1,379 \\
\hline & Urban & 89 & 0 & 0 & 39.4 & 259 \\
\hline & All categories & 3,320 & 17.6 & 4,294 & 48.4 & 11,848 \\
\hline \multirow[t]{5}{*}{ Coarse-grained deposits } & Undeveloped and nonbuilt up & 3,314 & 40.1 & 9,800 & 59.6 & 14,542 \\
\hline & Residential & 51 & 18.6 & 70 & 41.3 & 154 \\
\hline & Built up & 355 & 13.2 & 346 & 43.3 & 1,131 \\
\hline & Urban & 143 & 0 & 0 & 46.8 & 494 \\
\hline & All categories & 3,863 & 35.9 & 10,216 & 57.4 & 16,321 \\
\hline \multirow[t]{5}{*}{ Bedrock } & Undeveloped and nonbuilt up & 7,699 & 0 & 0 & 93.1 & 52,829 \\
\hline & Residential & 3 & 0 & 0 & 42.8 & 10 \\
\hline & Built up & 29 & 0 & 0 & 44.6 & 97 \\
\hline & Urban & 92 & 0 & $\mathbf{0}$ & 74.6 & 503 \\
\hline & All categories & 7,823 & 0 & 0 & 92.7 & 53,439 \\
\hline Total $^{2}$ & & 15,006 & 13.1 & 14,510 & 73.8 & 81,608 \\
\hline
\end{tabular}

${ }^{1}$ Recharge not estimated for bedrock areas and areas covered by large-surface water bodies, see figure 13 .

${ }^{2}$ Recharge totals include a value of 0 for bedrock area.

receiving more than about $60 \mathrm{in} / \mathrm{yr}$ of precipitation may have a larger error than estimates for areas with less than $60 \mathrm{in} / \mathrm{yr}$ of precipitation because of the lack of precipitation data-collection sites (and thus, the data used to derive the mean annual precipitation contours). Next, because of the large variability in the hydraulic characteristics of the fine-grained deposits, the estimates for fine-grained covered areas may have a large error associated with them. Additionally, implicit in the linear relation for fine-grained deposits (equation 3 ) is the assumption that the effective infiltration rate increases with increasing precipitation. Within the lowlying parts of the study area, this rate varies from about $0.0008 \mathrm{ft} / \mathrm{d}$ at $17 \mathrm{in} / \mathrm{yr}$ of precipitation to about $0.006 \mathrm{ft} / \mathrm{d}$ at $60 \mathrm{in} / \mathrm{yr}$. However, the recharge rate probably would approximate a constant value above some annual precipitation quantity because this increasing rate would exceed the maximum infiltration capacity of fine-grained deposits. Thus, rather than a linear relation such as defined by equation 3 , a nonlinear relation that would approach some constant value of recharge above some mean annual precipitation quantity may better define the recharge-precipitation relation for fine-grained deposits. In contrast, both the overlying soils and the outwash deposits have infiltration capacities that range from 6 to $20 \mathrm{in} / \mathrm{hr}$. These capacities are much higher than precipitation intensities in the Puget Sound Lowland. Thus, at larger values of mean annual precipitation with attendant increased cloudiness and decreased temperatures (decreased AET), the percentage of the precipitation that becomes recharge should increase. This again implies a nonlinear relation, but one that displays gradual upward curvature. Last, for the urban-type areas where recharge was set to zero, no attempt was made to estimate potential recharge due to leaking waterlines, sewer lines, storm drains, infiltration in small open spaces, and other factors that might contribute to recharge. Recharge is not zero in these areas, but estimating these quantities was beyond the scope of this study.

It should be noted that not all of the geologic settings found in the Puget Sound Lowland were represented in the 26 basins, for example, the setting where till directly overlies fine-grained interglacial deposits. Although this geologic setting is not common in the Puget Sound Lowland, it is known to occur (Lum and 
Walters, 1976). For this setting, the equations using precipitation as the dependent variable would yield larger estimates of recharge than would actually occur; estimated recharge would be greater than actual because of the low permeability of the fine-grained, predominately clay deposits underlying the till. Most areas with this geologic setting were too small for analysis at a regional scale. Thus, it should be noted that for localized investigations of areas with this type of setting, the regional estimates of mean annual recharge (fig. 13) developed during this study would probably need to be reduced substantially (Lum and Walters, 1976).

Mean annual recharge for the area overlying the Puget Sound aquifer system was estimated to be about $27 \mathrm{in} / \mathrm{yr}$ or $14,510 \mathrm{ft}^{3} / \mathrm{s}$ (about $10,500,000$ acre-ft of water-51 percent of precipitation). These estimates include about a 2 -in $/ \mathrm{yr}\left(1,050-\mathrm{ft}^{3} / \mathrm{s}\right)$ reduction in recharge due to land-use and cover effects described previously. For areas underlain by fine-grained deposits, recharge was estimated to be about $17.6 \mathrm{in} / \mathrm{yr}$ (36 percent of precipitation), and for areas underlain by coarse-grained deposits, recharge was about $35.9 \mathrm{in} / \mathrm{yr}$ (63 percent of precipitation). Estimated values ranged from zero in urban areas to more than $70 \mathrm{in} / \mathrm{yr}$ in some forest areas. Additionally, the total recharge is much larger than the estimated ground-water withdrawals in the Puget Sound Lowland, which was estimated for 1990 to be $826 \mathrm{ft}^{3} / \mathrm{s}$ on the basis of information previously presented in the "Cultural Setting" section.

For comparison, the Puget Sound Task Force (1970) estimated annual recharge "to the aquifer system in the lowlands of the study area" (the Puget Sound drainage basin) to be "conservatively" 800,000 acre-ft, and the Pacific Northwest River Basins Commission (1970) estimated annual recharge to the glacial and post-glacial deposits to be $5,700,000$ acre-ft. Neither of these estimates accounted for recharge to the Quaternary deposits in the mountainous areas where the estimated recharge rates are the largest. These values can be compared with this study's estimate of 9,350,000 acre-ft or $12,915 \mathrm{ft}^{3} / \mathrm{s}$ (reduced by the quantity of recharge-1,595 $\mathrm{ft}^{3} / \mathrm{s}$ - estimated to occur in the part of the Puget Sound Lowland in Canada). The $12,915 \mathrm{ft}^{3} / \mathrm{s}$ of mean annual recharge represents 60 percent and 26 percent of the median September and annual streamflow for the Puget Sound drainage basin in Washington.

\section{RELIABILITY OF ESTIMATES}

The reliability of the estimates of recharge (fig. 13 and table 6) can be assessed by comparing them with values from selected additional studies, to streamflow in selected basins, and to seasonal water-level changes. Additionally, because the estimates are based on mean annual values of precipitation, the potential interannual variability of recharge due to the interannual variability of precipitation also is of interest. These aspects are discussed in the following paragraphs.

In a study of the ground-water resources for $59 \mathrm{mi}^{2}$ of Pierce County, Drost (1982) used a water-budget method to estimate recharge to be about $86 \mathrm{ft}^{3} / \mathrm{s}$ or $20 \mathrm{in} / \mathrm{yr}$. The area-weighted estimate of recharge derived for this study (fig. 13) for the same $59-\mathrm{mi}^{2}$ area was $84 \mathrm{ft}^{3} / \mathrm{s}$ or about $19 \mathrm{in} / \mathrm{yr}$. The estimates from Drost (1982) and from this study are about 39 and 38 percent of mean annual precipitation, respectively. Hart Crowser and Associates, Inc. (1986) estimated recharge for five areas in a study for the city of Tacoma; these estimates were presented as a range in values for each area and appeared to account for the effects of impervious areas. Recharge was estimated to range from 10 to $17 \mathrm{in} / \mathrm{yr}$ ( 26 to 44 percent of mean annual precipitation) in four low-lying areas and to range from 38 to $60 \mathrm{in} / \mathrm{yr}$ (63 to 75 percent of mean annual precipitation) in an upland area. The estimates of recharge (fig. 13) for these same small and large precipitation areas (low-lying and upland) ranged from 6 to $25 \mathrm{in} / \mathrm{yr}$ and 41 to $60 \mathrm{in} / \mathrm{yr}$, respectively. These results indicate that the recharge values derived in this study are in general agreement with values estimated by other investigators.

Estimates of recharge for seven small lowland basins (fig. 7) ranging in area from 5.01 to $39.3 \mathrm{mi}^{2}$ were compared with observed mean annual streamflow and median 7-day, low-flow values (table 7). The information in table 7 indicates that these basins include a wide range of physical and hydrologic characteristics present in lowland areas of the Puget Sound Lowland. Also, note that, as with streamflow in most basins in the Puget Sound Lowland, in these basins the mean annual flows are nearly equivalent to both the mean April flows and the mean daily discharge that is exceeded 25 percent of the time. Therefore, these basins were assumed to be representative basins. Except for the case where streamflow in a basin is derived from ground water that originates outside the basin, mean annual recharge for a basin should be more than the median 7-day, low-flow discharge and less than the mean annual flow. Mean annual recharge was obtained from area-weighted values shown in figure 13.

Comparison of values of the estimated mean annual recharge and the observed streamflow for the basins (table 7) shows that recharge ranges from about 51 to 97 percent of the mean annual flow, and the median 7day, low-flow discharge ranges from about 14 to 64 percent of the recharge. Although for every basin the estimated recharge is less than the mean annual flow and greater than the median 7-day, low flow, there is a 


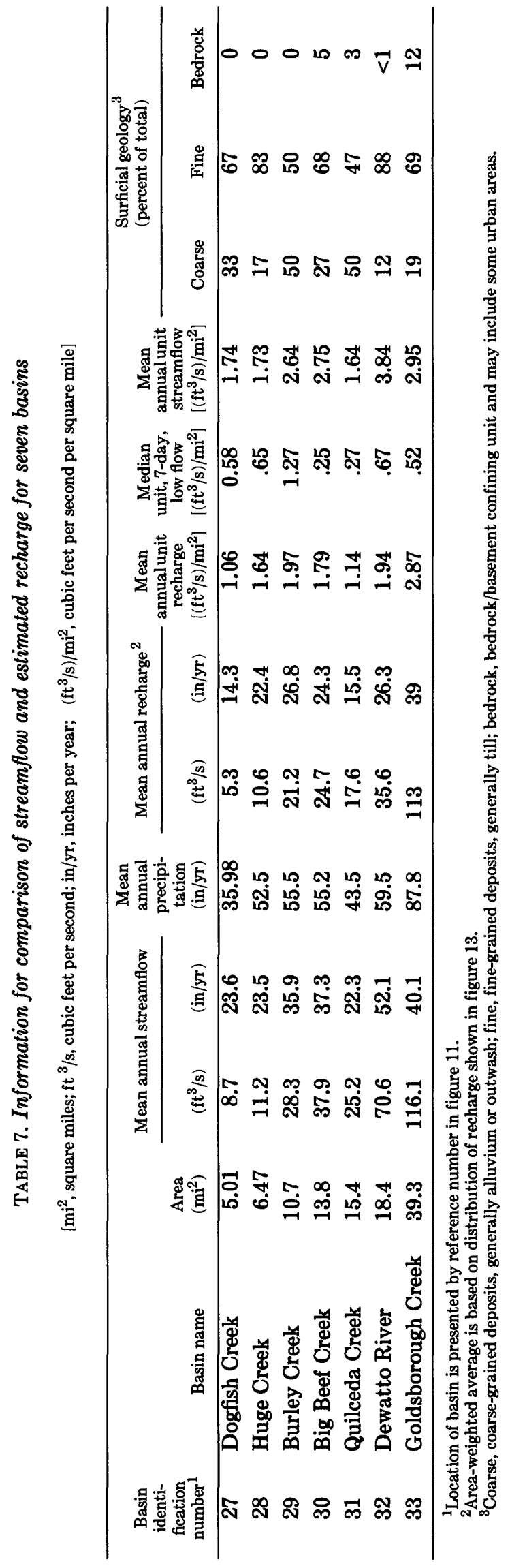


large range in percentages. The large range in percentages is partly due to the fact that some of the recharge will move vertically to deeper hydrogeologic units and that some may move laterally outside a basin so that some quantity of the recharge will not be available to supply water to a stream. In turn, the quantity that may or may not be available is controlled by the geologic and physical setting of a basin; these factors affect both the ground-water flow and surface runoff. In addition, the information presented in table 7 shows that the relation between ground-water and surface-water flow in the Puget Sound Lowland is highly variable and that recharge is only one of several factors that need to be considered in an analysis of basin runoff (also see table 4). The latter aspect is shown by the range in the median unit 7-day low-flow values (table 7). The smallest and largest values occur for Big Beef and Burley Creek Basins, respectively, which are similar in area and precipitation input. Although the estimated unit recharge values for these two basins are similar, the geologic and physical settings are different and, thus, affect the low-flow values. For example, because Burley Creek is in a low-lying basin located near saltwater, it obtains additional discharge, which has traveled over longer flowpaths, from the deeper ground-water system.

Water-level changes in the shallow deposits at or near the land surface generally can be grouped on the basis of three lithologic sequences: (1) coarse-grained deposits overlying till, (2) till, and (3) coarse-grained deposits directly underlying till. Seasonal water-level changes due to recharge from precipitation in these three sequences in the Seattle-Tacoma area typically are about 6 to $8 \mathrm{ft}$ (Walters and Kimmel, 1968), 2 to $8 \mathrm{ft}$ (Walters and Kimmel, 1968; Dion and others, 1983), and 1 to $5 \mathrm{ft}$ (Walters and Kimmel, 1968; Drost, 1982; Carr and Associates, 1983), respectively. Using the estimated maximum water-level changes $(8,8$, and $5 \mathrm{ft}$, respectively) and estimated specific yields of $0.25,0.10$, and 0.20 for the three sequences or units, respectively, gives 24.0,9.6, and $12.0 \mathrm{in}$. as the quantity of water needed to account for the change in maximum water levels. The last value is based on the assumption that the waterlevel change in the deposits underlying till occurs under water-table conditions. Also, note that if the water-level changes in deposits underlying till are assumed to be supported mainly by water that has moved through the till, then the latter two values of recharge should be similar. Using a mean annual precipitation of $40 \mathrm{in} / \mathrm{yr}$ yields $14.85 \mathrm{in} / \mathrm{yr}$ of recharge for areas underlain by till (equation 3 , table 5) and $23.75 \mathrm{in} / \mathrm{yr}$ of recharge for areas underlain by outwash deposits (equation 6, table 5). These values are in general agreement with those estimated using maximum observed water-level changes. Although the response of water levels to recharge from precipitation is more complex than just described, the recharge still needs to be sufficient to support observed water-level changes. For example, an estimated recharge value of 5 to $10 \mathrm{in} / \mathrm{yr}$ could not support an 8-ft water-level change in the coarse-grained deposits and would indicate that the estimated value was too small.

The estimated regional recharge distribution (fig. 13) is assumed to represent a long-term average. As discussed previously, the interannual variability in these estimates can be expected to be generally similar to the interannual variability of precipitation. Therefore, to understand the variability of recharge in the Puget Sound Lowland, equations 3 and 6 (table 5) were used to estimate annual recharge for fine-grained and coarsegrained deposits, respectively, at two weather stations. These weather stations have a long period of record and are representative of the range in precipitation within the low-lying parts of the Puget Sound Lowland. The small-precipitation site (average water-year precipitation of $19 \mathrm{in} / \mathrm{yr}$ ) is near Port Townsend, and the largeprecipitation site (average water-year precipitation of $53 \mathrm{in} / \mathrm{yr}$ ) is near Olympia. Other precipitation information for these sites is shown in figures $3 A$ and $3 B$ and at the beginning of this section.

Recharge at the Port Townsend site ranged from 0.15 to $12.48 \mathrm{in} / \mathrm{yr}$ for fine-grained deposits and from 0 to $19.56 \mathrm{in} / \mathrm{yr}$ for coarse-grained deposits (fig. 14). At the Olympia site, annual recharge ranged from 10.7 to $35.5 \mathrm{in} / \mathrm{yr}$ for fine-grained deposits and from 16.7 to $56.9 \mathrm{in} / \mathrm{yr}$ for coarse-grained deposits (fig. 14). The information presented in figure 14 thus indicates both the spatial and temporal variability in recharge and, potentially, in ground-water availability that may occur in the study area. The information also indicates the importance for detailed analyses of recharge for local studies and shows that the estimates of recharge for any location (fig. 13) are long-term averages of widely varying values.

The information shown in figure 14 indicates additional limitations and aspects concerning the relations given in table 5 . First, note that, at about $13.5 \mathrm{in} / \mathrm{yr}$ of precipitation, the regression relation for coarse-grained deposits gives smaller quantities of recharge than does the relation for fine-grained deposits. This difference shows the problem of using relations for mean annual values to estimate annual recharge values. The problem is due to the fact that annual precipitation values may be outside of the range in values used to develop the regression relations (tables 4 and 5). This is the case for many of the precipitation values at the Port Townsend site. This particular problem is mainly related to small precipitation values (the limitations for large 


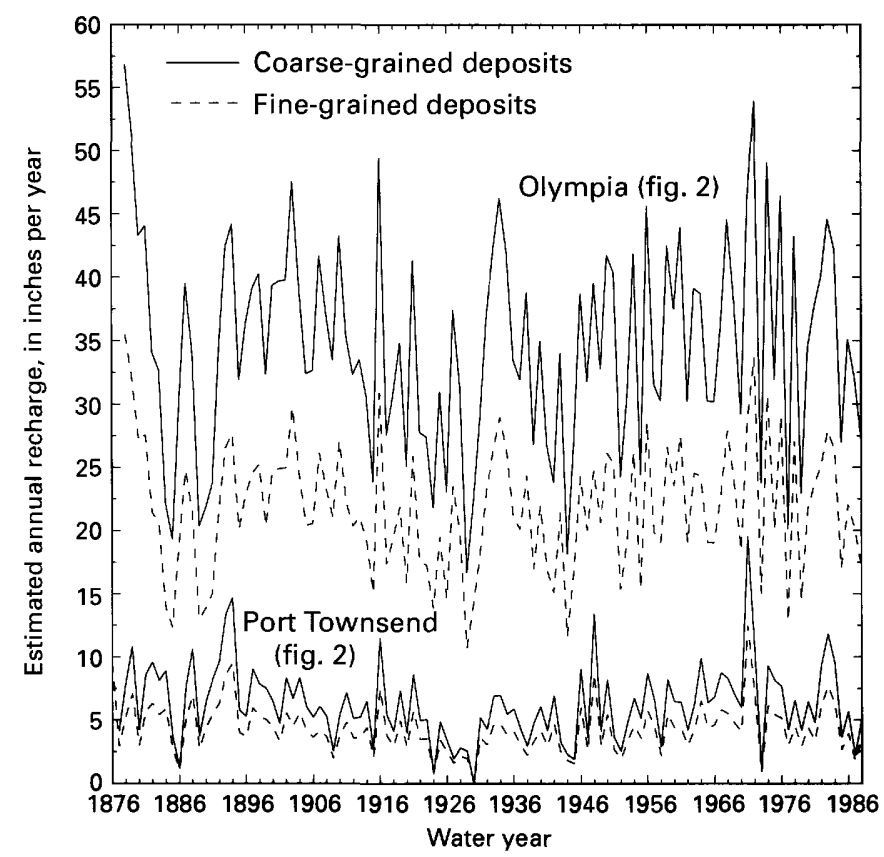

FIGURE 14.-Estimated distribution of annual recharge at two weather stations, representative of small- and large-precipitation areas, for two different surficial geologic units.

precipitation values were described previously). The major aspect suggested by this limitation is the need to estimate recharge in a small-precipitation area for both types of deposits using daily water-budgeting methods for a long simulation period. This would provide additional information for (1) developing more accurate relations and (2) improving the understanding of the interannual variability in recharge in this climatic setting. However, although annual precipitation within the Puget Sound Lowland may be much smaller than the smallest value used to develop the relations, small values may not be a major limitation because the mean annual precipitation is more than about $16 \mathrm{in} / \mathrm{yr}$ everywhere in the Puget Sound Lowland and is more than $27 \mathrm{in} / \mathrm{yr}$ in most of the Puget Sound Lowland.

The relation between the interannual variability of precipitation and recharge and the subsequent response of water levels because of recharge variations was recognized early in the Puget Sound Lowland by Walters and Kimmel (1968) and Anderson (1968). Walters and Kimmel (1968) show that the timing and magnitude of the winter peak in water levels is related to both differences and trends in annual precipitation. Walters and Kimmel (1968) further show that seasonal water-level changes can have annual differences of at least $4 \mathrm{ft}$; for 1945-50, there was a positive trend in precipitation (fig. 4) and a corresponding trend in the annual water levels in selected wells of about $4 \mathrm{ft}$. Annual precipitation at Tacoma varied by as much as $20 \mathrm{in}$. during this period, and equation 3 (table 5) indicates recharge could have varied by $10 \mathrm{in}$., or using a specific yield of 0.20 , water levels could have varied by about $4 \mathrm{ft}$. Anderson (1968) shows the effects of variations in precipitation on water levels for 1964 and 1965; the winter peak in the water level for 1965 was about $4 \mathrm{ft}$ higher than in 1964 when precipitation was substantially less than 1965.

\section{WATER-QUALITY CHARACTERISTICS}

Previous assessment of ground-water quality in the Puget Sound Lowland has ranged from site-specific investigations of contaminants in ground water or soils (Tracey and Dion, 1976; Hart Crowser and Associates, 1984; Lum and Turney, 1985; Turney and Goerlitz, 1988; and URS Consultants, Inc., 1992) to statewide and nationwide studies (VanDenburgh and Santos, 1965; Foxworthy, 1979; Molenaar and others, 1980; Lum and Turney, 1982). Specific investigations that have included assessment of seawater intrusion and general quality of the ground water for counties and other large areas have been carried out since the early 1970's (Walters, 1971; Drost, 1982, 1985; Whiteman and others, 1983; Dion and Sumioka, 1984; Jones, 1985; Dion and others, 1988, 1994; Woodward and others, in press). Additionally, an assessment of the ground-water quality for the Puget Sound region (Turney, 1986) was completed as part of a statewide assessment. Ground-water-quality investigations of the part of the aquifer system in British Columbia have been completed by Kwong (1986), Kohut and others (1989), Liebscher and others (1992). A summary of the historical ground-water-quality data for selected constituents for the part of the study area within the State of Washington is given in table 8; both the average and median values of the analyses are presented in table 8 . The data are based on 5,131 analyses that were in NWIS as of October 1992.

The dominant water types in the upper aquifer units are calcium bicarbonate, magnesium bicarbonate, or calcium magnesium bicarbonate. Deeper aquifer units, in addition, contain ground water of a sodium bicarbonate or a sodium chloride type. Generally, sodium bicarbonate water has been attributed to proximity to consolidated bedrock, to longer residence time in the ground-water system, and to the presence of finegrained marine deposits of recent age (Whiteman and others, 1983; Dion and others, 1988; G.L. Turney, U.S. Geological Survey, written commun., 1994). The sodium bicarbonate water also contains larger concentrations of dissolved solids. Sodium chloride water generally is associated with mixing of native ground water with seawater; this water also has larger concentrations of magnesium. 
TABLE 8. Summary of historical ground-water-quality data

[Values in milligrams per liter unless otherwise indicated; cols $/ 100 \mathrm{~mL}$, colonies per 100 milliliters of water; $\mu \mathrm{g} / \mathrm{L}$; micrograms per liter]

\begin{tabular}{|c|c|c|c|}
\hline Constituent & Average & Median & $\begin{array}{l}\text { Number of sampling } \\
\text { sites }\end{array}$ \\
\hline Specific conductance (microsiemens per centimeter at 25 degrees Celsius) & 365 & 180 & ${ }^{1} 4,414$ \\
\hline pH (standard units) & 7.3 & 7.3 & 1,905 \\
\hline Hardness $\left(\right.$ as $\left.\mathrm{CaCO}_{3}\right)$ & 81 & 60 & 1,960 \\
\hline Alkalinity, total $\left(\mathrm{as} \mathrm{CaCO}_{3}\right)$ & 81 & 65 & 1,113 \\
\hline Dissolved solids, calculated (sum of constituents) & 164 & 112 & 1,668 \\
\hline Calcium, dissolved & 17 & 13 & 1,871 \\
\hline Magnesium, dissolved & 8.2 & 5.9 & 1,871 \\
\hline Sodium, dissolved & 23 & 6.5 & 1,735 \\
\hline Sodium-adsorption ratio & 1.2 & .4 & 1,699 \\
\hline Potassium, dissolved & 2.4 & 1.8 & 1,722 \\
\hline Sulfate, dissolved & 9.2 & 5.0 & 1,789 \\
\hline Chloride, dissolved & 55 & 4.7 & $1_{4,371}$ \\
\hline Silica, dissolved $\left(\mathrm{as}^{\mathrm{SiO}}{ }_{2}\right)$ & 30 & 29 & 1,713 \\
\hline Nitrate plus nitrite (as N), dissolved & 1.4 & .10 & 1,117 \\
\hline Iron, dissolved $(\mu \mathrm{g} / \mathrm{L})$ & 920 & 38 & 1,314 \\
\hline Manganese, dissolved ( $\mu \mathrm{g} / \mathrm{L})$ & 130 & 17 & 1,207 \\
\hline Bacteria, fecal-coliform (cols $/ 100 \mathrm{~mL})$ & 1.2 & 1.0 & 1,072 \\
\hline
\end{tabular}

${ }^{1}$ Most of the samples collected as part of seawater-intrusion investigations.

Although large concentrations of chloride are typically found in ground water near the shoreline, S.E. Cox (U.S. Geological Survey, written commun., 1993) found large concentrations of chloride in water at depth in deposits several miles inland from the shoreline in the Fraser-Whatcom Basin in Whatcom County. It appears that this water is contained in glaciomarine drift. After the drift was deposited, its subsequent burial at shallow depths during the Sumas Stade may have been so rapid that the contained saltwater was not flushed out. Within the part of the study area in British Columbia, Halstead (1986) mapped large concentrations of chloride in ground water in both the glaciomarine drift and some of the alluvial deposits. The water-level configurations (fig. 10) indicate that the chloride in the alluvial deposits is derived from water that has moved through the glaciomarine drift into the alluvial deposits.

Ground water in the study area is generally soft to moderately hard, as indicated by the median hardness value of $60 \mathrm{mg} / \mathrm{L}$ (table 8). The hardness is determined by the calcium and magnesium concentrations in the ground water; in areas with larger concentrations of these constituents, the water may vary from hard to very hard, such as in parts of San Juan and Island Coun- ties (Turney, 1986). Because sodium is not a dominant cation in ground water in the Puget Sound Lowland, the sodium-adsorption ratio (SAR) is generally less than 2 and has a median value of 0.4 . In areas with larger sodium concentrations or a sodium chloride water type, the SAR has been found to be as large as 30; these areas are usually associated with both seawater intrusion and larger concentrations of dissolved solids (and larger specific-conductance values). Dissolved solids generally are in the range of 100 to $150 \mathrm{mg} / \mathrm{L}$; larger values in the range of 300 to $500 \mathrm{mg} / \mathrm{L}$ are found in the ground water in low-lying areas adjacent to Puget Sound and are commonly related to seawater intrusion. Generally, large dissolved-solids concentrations are associated with a sodium chloride water type, and small concentrations are associated with calcium bicarbonate and calcium magnesium bicarbonate types.

Elevated concentrations of iron and manganese as large as 2,500 and $650 \mu \mathrm{g} / \mathrm{L}$, respectively, have been found in the glacial aquifers in the Puget Sound Lowland. Water-sample analyses in some of the coastal areas also have shown that manganese can be more abundant than iron, which is atypical of glacial aquifers (Dion and others, 1988). The large differences between 
the average (which is affected by extreme values) and median values for both dissolved iron and manganese indicate that quite a few sites had elevated concentrations.

Concentrations of dissolved nitrate plus nitrite (herein referred to as nitrate) generally are small in the ground water in the study area; most reported values are less than $1.0 \mathrm{mg} / \mathrm{L}$ expressed as nitrogen, and the median nitrate concentration is about $0.10 \mathrm{mg} / \mathrm{L}$. The order of magnitude difference between the average and median nitrate indicates that locally large concentrations of nitrate have been observed. Moderate to large concentrations of nitrate have been found in Thurston, Pierce, Skagit, and Whatcom Counties. Larger concentrations in parts of Thurston and Pierce Counties may be derived from septic-waste disposal systems in the extensively developed, unsewered residential areas. The larger concentrations found in Skagit and Whatcom Counties, both of which have large agricultural areas, may be derived from feedlot wastes or fertilizers. The sampled wells with larger concentrations of nitrate generally occur in areas overlain by coarse-grained deposits and, thus, may be attributed to the rapid movement of water with large nitrate concentrations to the water table. The vertical distribution of tritium concentrations obtained from soil water in unsaturated till shows pre-1964 water still contained within the till in some areas (H.H. Bauer, U.S. Geological Survey, written commun., 1994), indicating that large concentrations of nitrate are not found in aquifers covered by till or finegrained deposits because water with large concentrations of nitrate may not yet have reached the water table.

Although Turney (1986) reported a maximum value of nitrate of $9.3 \mathrm{mg} / \mathrm{L}$ in Whatcom County, a 1992 study of part of Whatcom County has observed values of more than $40 \mathrm{mg} / \mathrm{L}$ (S.E. Cox, U.S. Geological Survey, written commun., 1993). In this study of Whatcom County, samples collected from closely spaced wells open to different depths in the aquifer system showed that the largest concentrations were found in the shallow wells and that there was a rapid decrease in nitrate concentrations with depth, indicating that the large concentrations were probably due to local sources at the land surface. This part of the aquifer system in Whatcom County is contained in the structural Fraser-Whatcom Basin, which includes the Fraser Lowland of British Columbia. Kwong (1986), Kohut and others (1989), and Liebscher and others (1992) also found elevated concentrations of nitrate in part of the Puget Sound Lowland within British Columbia. About onethird of the major aquifer unit (the Abbotsford aquifer) studied by Kohut and others (1989) and Liebscher and others (1992) extends into Whatcom County. Liebscher and others (1992) observed nitrate concentrations in the ground water that were as much as $41 \mathrm{mg} / \mathrm{L}$ and concluded that large nitrate concentrations generally are site specific, fluctuate seasonally, and are due to landuse activities; additionally, 12 of 23 pesticides that were sampled for were detected in the ground water.

Seawater has intruded some aquifers near the coast, most commonly in the island and peninsular areas of the Puget Sound Lowland and near large coastal pumping centers. Aquifer units that are below sea level contain larger concentrations of chloride and show seasonal fluctuations in concentrations in selected locations (Sapik and others, 1988). A chloride concentration value of more than $100 \mathrm{mg} / \mathrm{L}$ has been used as an indicator of seawater intrusion in the Puget Sound Lowland (Walters, 1971; Dion and Sumioka, 1984; Dion and others, 1988; Sapik and others, 1988). Seawater intrusion has been most prevalent in San Juan and Island Counties. For example, in a study of San Juan County, Whiteman and others (1983) showed that of 279 wells sampled in 1981, 9 percent had chloride concentrations indicative of seawater intrusion. A similar study of Island County showed that about 20 percent of 330 wells sampled were in areas intruded by seawater (Sapik and others, 1988). Seawater intrusion is most prevalent in these counties because of the small recharge quantities (fig. 13), low topographic relief, and the small extent of the Puget Sound aquifer system (fig. 3).

In summary, the quality of the ground water in the Puget Sound aquifer system is good and suitable for most uses. Larger concentrations of selected constituents can be attributed to locally derived sources. The large quantity of recharge that enters the aquifer system, large values of hydraulic conductivity, and short flowpaths generally result in a nearly vertically homogeneous system with respect to general constituent concentrations. Proximity to saltwater and selected types of bedrock can locally affect the chemistry, and thus, the quality of the flowing ground water. The potentially important water-quality problems are related to seawater intrusion and locally derived sources of nitrogen. However, site-specific ground-water contamination has occurred and may continue to occur because of anthropogenic sources. Although rarely a health problem, larger concentrations of iron and manganese in parts of the glacial aquifers may be considered a significant aesthetic problem.

\section{GROSS-SEGTIONAL NUMERICAL MODELS OF GROUND-WATER FLOW}

Six cross-sectional numerical models of groundwater flow were constructed to provide (1) an improved 
understanding of both the ground-water flow system (hydraulic-head distribution and water budgets) and the major controls on the flow system and (2) information for developing a simplified regional conceptual model of the aquifer system. The grid systems and hydraulic characteristics of the models were varied by aggregating hydrogeologic units (simplifying the aquifer system geometry) to test conceptual models of the aquifer system. The models were constructed for hydrogeologic sections in "type" areas; traces of the sections are shown on plate 1 . To the extent possible, the sections were constructed so that they lie along flowpaths as delineated by the generalized water-level configurations (fig. 10) and by local studies (Sapik and others, 1988; G.L. Turney, U.S. Geological Survey, written commun., 1994; Woodward and others, 1995). The relations between model layers (plate 1) and the local hydrogeologic units discussed previously are given in table 9 .

Ground-water flow was simulated using the finitedifference model MODFLOW (McDonald and Harbaugh, 1988) that was modified by Hansen (1993). The models were operated under steady-state conditions with the top active cell as a water table and all other cells fully convertible to a water table. The modelcalculated heads and water-budget components represent long-term mean annual values.

The following sections describe (1) the construction of the cross-sectional models (including the model grid, boundary conditions, and hydraulic characteristics), calculated ground-water flow, and calculated waterbudget components and (2) evaluation of the results of the models and other pertinent information for developing a simplified conceptual model of the aquifer system. The latter is discussed in conjunction with the description of the flow systems and water budgets.

\section{MODEL GRID SYSTEMS}

The model grid systems for the six models for both the detailed and aggregated aquifer-system geometry are shown on plate 1, and general information for the grid systems is given in table 10 . The shortest section ( $D-D^{\prime}$, Bainbridge Island-2) is about $2.3 \mathrm{mi}$ long, and the longest section ( $E-E^{\prime}$, South King County) is about $19.5 \mathrm{mi}$ long. Where applicable, sections initially were extended offshore to account for the saltwater interface.

The vertical discretization of the aquifer system was, with one exception, based on the number of mapped hydrogeologic units in each section. Because of lack of information on the subsurface distribution of units below the small topographic high situated in the Green River Valley in section $E-E^{\prime}$ and the outcrop of coarse- grained materials at the eastern base of this high, the alluvial unit was assumed to exist throughout the valley and, thus, was defined as one unit. Each unit was discretized and simulated as a separate model layer; the deeper undifferentiated deposits generally were arbitrarily discretized with two layers. Where both layers of undifferentiated deposits exist, the upper layer was defined by a relatively constant thickness. As a result, the models were constructed with 6 to 10 layers (table 10). The vertical discretization for the model cells of each layer was based on the average thickness of the mapped unit for the appropriate cell length and location. Horizontal discretization for the model cells was based on the extent of the mapped units over the length of a section. The longitudinal cell size was uniform within each cross section but varied from 1,100 to $1,800 \mathrm{ft}$ among sections. The transverse dimension or width size perpendicular to the section was set equal to the longitudinal dimension (cells, thus, were square in the horizontal dimension). The cell size used in the models allowed for simulation of local flow systems.

The models initially were operated to determine the reasonableness of both the boundary conditions (discussed in the next section) and the initial discretization of saltwater boundaries. The location of the freshwatersaltwater interface for each model, where appropriate, also was calculated using the Ghyben-Herzberg equation (Hubbert, 1940) under the assumption that the hydraulic-head distribution in the freshwater part of the flow system is hydrostatic. Although the position of the interface estimated using the Ghyben-Herzberg equation is not exact due to the effects of vertical head gradients in the freshwater and vertical and horizontal head gradients in the saltwater, and acknowledging that the interface is affected by variations in tides, currents, recharge, and pumpage, it is still reasonable to use this information to guide the discretization of the aquifer system, especially considering the purpose of constructing the models and the potentially large width of the saltwater transition zone in the Puget Sound Lowland (Sapik and others, 1988; R.C. Lane, U.S. Geological Survey, written commun., 1993). Together, the results from the preliminary model simulations and the interface calculated using the Ghyben-Herzberg equation were then used to define the freshwater-saltwater boundary used in the subsequent simulations. Additionally, for sections $A-A^{\prime}$ and $B-B^{\prime}$, the model results of Sapik and others (1988) were used as the principal guide for defining the freshwater-saltwater boundary.

The model grid systems were later modified to test a conceptual model of the regional aquifer system. Several layers were aggregated (combined) into a single layer for each of the models for this test. Calculated heads, hydraulic gradients, water-budget components, 
TABLE 9. Relation between model layers and local hydrogeologic units and the potential relations between hydrogeologic and stratigraphic units

\begin{tabular}{|c|c|c|c|}
\hline $\begin{array}{l}\text { Section } \\
\text { (plate 1) }\end{array}$ & Layer $^{1}$ & Hydrogeologic unit ${ }^{2}$ & Stratigraphic unit ${ }^{3}$ \\
\hline \multirow[t]{11}{*}{$\overline{A-A^{\prime}, B-B^{\prime}}$} & 1 & $\mathbf{Q r}$ & Everson "glaciomarine" Drift-recessional outwash \\
\hline & 1 & Qt & Vashon till \\
\hline & 2 & aql & Advance outwash-Esperance Sand Member \\
\hline & 3 & nonaql & Lawton Clay/Pilchuck Clay/Quadra Formation \\
\hline & 4 & aq2 & Quadra Formation \\
\hline & 5 & nonaq2 & Possession Drift \\
\hline & 6 & aq3 & Lower Possession Drift-upper Whidbey Formation \\
\hline & 7 & nonaq3 & Whidbey Formation \\
\hline & 8 & aq4 & Double Bluff Drift \\
\hline & 9 & nonaq4 & $?$ \\
\hline & & bcu & Bedrock, basement confining unit \\
\hline \multirow[t]{6}{*}{ C-C', D-D' } & 1 & Qr & Vashon till \\
\hline & 2 & aq1 & Advance outwash_Esperance/Colvos Sand Member \\
\hline & 3 & nonaq1 & Kitsap Formation \\
\hline & 4 & aq2 & Upper Salmon Springs Drift \\
\hline & 5,6 & undiv & Salmon Springs Drift and older deposits \\
\hline & & bcu & Bedrock, basement confining unit \\
\hline \multirow[t]{9}{*}{$\mathbf{E}-\mathbf{E}^{\prime}$} & 1 & a1 & Alluvium, Green River \\
\hline & 2 & Qr & Recessional outwash \\
\hline & 3 & Qt & Vashon till \\
\hline & 4 & aq1 & $\begin{array}{l}\text { Advance outwash-or-advance outwash-Colvos } \\
\text { Sand Member }\end{array}$ \\
\hline & 5 & nonaq1 & Advance outwash-or-Kitsap Formation \\
\hline & 6 & aq2 & $\begin{array}{l}\text { Advance outwash-Colvos Sand Member-or-Salmon } \\
\text { Springs Drift }\end{array}$ \\
\hline & 7 & nonaq2 & Kitsap Formation-or-Puyallup Formation \\
\hline & 8,9 & undiv & $\begin{array}{l}\text { Salmon Springs Drift and older deposits-or-Stuck } \\
\text { Drift and older deposits }\end{array}$ \\
\hline & & bcu & Bedrock, basement confining unit \\
\hline \multirow[t]{8}{*}{ F-F' } & 1 & a1 & Alluvium, Nisqually River \\
\hline & 2 & Qr & Recessional outwash \\
\hline & 3 & Qt & Vashon till \\
\hline & 4 & aq1 & Advance outwash-Colvos Sand Member \\
\hline & 5 & nonaq1 & Kitsap Formation-(Salmon Springs till?) \\
\hline & 6 & aq2 & Upper Salmon Springs Drift \\
\hline & 7,8 & undiv & Salmon Springs Drift and older deposits \\
\hline & & bcu & Bedrock, basement confining unit \\
\hline
\end{tabular}




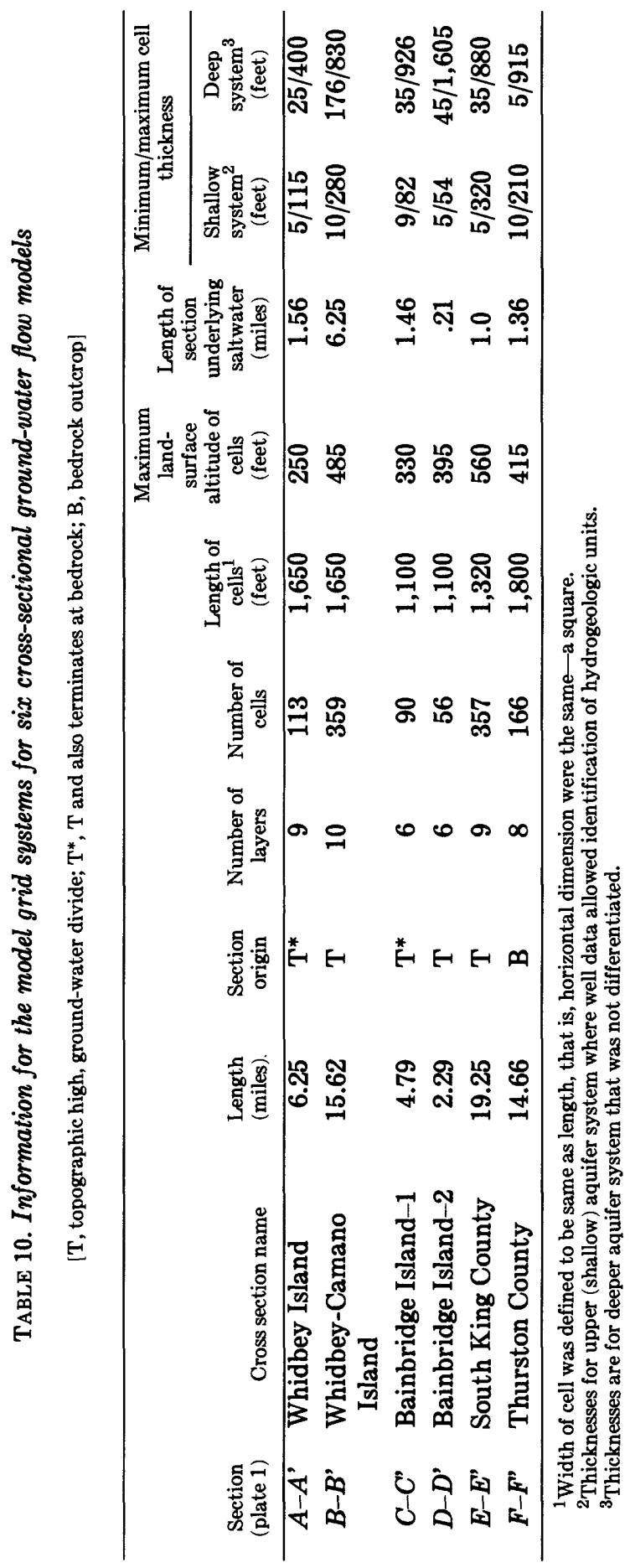


locations of discharge, and flowpaths then were compared for these two formulations of the aquifer-system geometry. The comparison was done to determine if the calculated flow system for the aggregated or simplified geometry retained the principal features of the more complex natural system and, thus, could be used to help develop a conceptual model of the aquifer system.

For the aggregation, excluding the alluvial unit present in the alluvial valley in section $E-E^{\prime}$, all the layers above the first major (areally extensive) finegrained, generally clay unit were combined into one layer. The fine-grained layer was chosen so that it generally corresponded to the first major interglacial unit, generally the Kitsap or Whidbey Formations (fig. 5; table 9); these units generally are located near sea level where they abut saltwater bodies. The fine-grained unit was retained as a layer, as were the layers representing the deeper undifferentiated deposits; the fine-grained unit and the deeper deposits were described previously in the "Hydrogeologic Units" section-the fine-grained unit as "nonaq" and the deeper deposits as "undiv" (also see table 9). In addition, to test what was possibly the maximum aggregation of units, all units above the finegrained (nonaq) unit that lie below the sea-level nonaq unit were combined into a single layer for sections $A-A^{\prime}$ and $B-B^{\prime}$. The aggregated or simplified layers also are shown on plate 1 .

\section{BOUNDARY CONDITIONS}

The boundary conditions for the cells at land surface (water-table cells) for all models were input mean annual recharge rates. Total flux to each of these cells is calculated by the model as the input rate (table 11) multiplied by the area of the cell. Excluding sections $A-A^{\prime}$ and $B-B^{\prime}$, the recharge rates were estimated on the basis of estimates of recharge presented in figure 13. For sections $A-A^{\prime}$ and $B-B^{\prime}$, estimates of recharge for a threedimensional model of the ground-water flow system of Island County (Sapik and others, 1988) were used as model input. The boundary condition for the contact between the Quaternary deposits and the basement confining unit was simulated as no flow. Additionally, the south end of section $D-D^{\prime}$, a ground-water divide, was simulated as no flow.

The boundary condition for each cell at the downstream, terminal end or ends of each section within saltwater was defined as either a head-dependent function (HDF) or a no-flow boundary. The HDF was used to simulate seepage faces or spring discharge. The controlling head for the cells with a HDF in direct contact with saltwater was defined as (set equal to) an equivalent freshwater head using the rewritten GhybenHerzberg relation:

$$
H_{f}=0.021 \times D,
$$

where $H_{f}$ is the controlling head (equivalent freshwater head referenced to sea level); $D$ is the depth, in feet, of the center of the cell below sea level; and 0.021 is the average difference in specific gravity between the saltwater of Puget Sound (1.021) and freshwater (1.0). The head-dependent boundary condition was used to calculate the quantity of water discharging from the ground-water system to saltwater. The extension of the sections, where applicable, to include deposits underlying saltwater allows for an improved simulation of that discharge. Under the assumption of a sharp interface and movement of water parallel to it, no-flow boundaries were used for selected interface cells for the sections with an extensive interface; for example, see sections $C-C^{\prime}$ and $F-F^{\prime}$ on plate 1 .

For all layers that terminate at a bluff or in a canyon, a head-dependent boundary condition also was used. These boundaries were simulated using either the drain or the general head boundary (GHB) module of MODFLOW; the GHB's were only used in simulation of flow for sections $C-C^{\prime}$ and $E-E^{\prime}$. In the mathematical formulation of MODFLOW, ground water in drain cells can only discharge water from the aquifer system, and ground water in GHB cells can both discharge and recharge the system. The altitude chosen for the controlling head for these boundaries was the bottom

TABLE 11. Ranges in recharge estimates and hydraulic characteristics for six cross-sectional ground-water flow models

\begin{tabular}{clrcc}
\hline Section & \multicolumn{1}{c}{ Cross section name } & $\begin{array}{c}\text { Recharge } \\
\text { (inches per year) }\end{array}$ & $\begin{array}{c}\text { Horizontal hydraulic } \\
\text { conductivity } \\
\text { (feet per day) }\end{array}$ & $\begin{array}{c}\text { Vertical conductance } \\
\text { (feet per day per foot) }\end{array}$ \\
\hline$A-A^{\prime}$ & Whidbey Island & $6.09-10.27$ & $0.01-302.4$ & $2.2 \times 10^{-5}-7.8 \times 10^{-4}$ \\
$B-B^{\prime}$ & Whidbey-Camano Island & $5.76-14.80$ & $0.01-216.0$ & $4.9 \times 10^{-6}-2.3 \times 10^{-4}$ \\
$C-C^{\prime}$ & Bainbridge Island-1 & $13.86-14.28$ & $0.52-10.37$ & $1.7 \times 10^{-6}-3.5 \times 10^{-4}$ \\
$D-D^{\prime}$ & Bainbridge Island-2 & $16.32-17.70$ & $0.02-60.48$ & $6.0 \times 10^{-7}-5.2 \times 10^{-4}$ \\
$E-E^{\prime}$ & South King County & $13.63-34.07$ & $0.16-66.53$ & $4.3 \times 10^{-5}-1.4 \times 10^{-2}$ \\
$F-F^{\prime}$ & Thurston County & $15.60-30.17$ & $6.05-1,469$ & $7.8 \times 10^{-5}-7.8 \times 10^{-2}$ \\
\hline
\end{tabular}


altitude of the cell or, in the case where only part of the layers crop out, the bottom altitude of the outcrop. Although not strictly a boundary condition, cells with surface-water bodies, such as streams and lakes (excluding large rivers), also were identified as drain cells.

To differentiate between discharge occurring below sea level from that occurring above sea level through seepage faces, springs, or streams (together these three are herein referred to as "seeps"), the discharge from cells that were below sea level was simulated using the river module. Although water can both discharge and recharge the aquifer system in the formulation of the river module, water only discharged in the cross-sectional models because the controlling altitude was always less than the calculated heads.

The ET module of the ground-water flow model was used in all of the cross-sectional models. The component of ET calculated is the ET from the ground water, which approximates PET minus evaporation and plant transpiration from the unsaturated zone; that is, PETAET (see table 4). The physical setting along sections $E-E^{\prime}$ and $F-F^{\prime}$ indicated that ET probably was an important component of the water budget. For section $E-E^{\prime}$, ground-water levels are near land surface in the broad flat alluvial valley. For section $F-F^{\prime}$, the northern part of the section lies along flat topography in a river delta; in this area, ground-water levels are essentially at land surface. The ET module was used for the other four sections to test whether ET also might be an important component. All cells at land surface for these other four sections were initially identified as ET cells. Later, only those cells for which ET may occur (as estimated by preliminary simulations) were assigned an ET rate.

Of the six sections, only one $\left(E-E^{\prime}\right)$ contains a major stream (the Green River) located in an alluvial valley. Discharge to the river was simulated using the GHB module of the ground-water flow model. Additionally, section $E-E^{\prime}$ contained a small creek within the alluvial valley; discharge to this creek also was simulated using the GHB module. Discharge to these cells was printed out separately for each simulation to identify that discharge. The locations of the drain, GHB, ET, and river cells for each model are shown on plate 1 .

\section{HYDRAULIC GHARACTERISTIGS}

Horizontal hydraulic conductivity for each unit was initially estimated from available specific-capacity data in the area of a section and the regional compilation of values completed in this study (table 3 ). For sections $A-$ $A^{\prime}$ and $B-B^{\prime}$ (plate 1 and table 10), the initial hydraulicconductivity values used were those of Sapik and others
(1988), who estimated values on the basis of a threedimensional, ground-water flow model.

The flow model uses vertical conductance as the hydraulic characteristic that controls the vertical movement of water between layers. Vertical conductance between the cells of two layers is approximated by the effective vertical hydraulic conductivity of the cells divided by the sum of one-half the thickness of the cells. Initial estimates of the effective vertical hydraulic conductivity were computed as 0.1 times the harmonic mean of horizontal-conductivity values of the cells of the two layers in contact.

Initial drain, GHB, and river conductances were chosen as two times the initial estimate of transmissivity of the cell (equal to the lateral hydraulic conductivity multiplied by the saturated thickness) (Sapik and others, 1988). The ranges in the final lateral hydraulic conductivity and the vertical conductance for each model, together with the ranges in the estimates of recharge, are presented in table 11.

\section{GALCULATED FLOW SYSTEMS}

The calculated hydraulic heads for each cross-sectional model (plate 1) show the large variability in ground-water flow systems present within the study area. The variability in flow systems is exhibited in modeling results using both the detailed and aggregated geometry of the aquifer system. This section describes the following three aspects of these flow systems (assumed to be representative of those present in the Puget Sound Lowland) based on the results of the models: (1) hydrologic controls on the ground-water flow systems, (2) horizontal and vertical head gradients present in the flow systems, and (3) flowpaths. On the basis of these three aspects for both the detailed and aggregated aquifer-system geometries, some general conclusions are described.

Four major hydrologic controls are described: (1) topography, (2) the presence of saltwater bodies, (3) fine-grained units, and (4) the configuration of the geometry of the basement confining unit. Hydraulichead gradients are described because gradients (1) indicate the direction of ground-water flow and (2) are an integrated function of aquifer-system geometry, recharge, hydraulic characteristics, stream-aquifer hydraulic connection, and pumpage. Additionally, gradients provide a measure for comparison of aquifer systems. Flowpaths then are briefly described on the basis of the result of models and generalized paths estimated using the water-level configurations (fig. 10). Flowpaths indicate (1) the path taken by ground water as it moves from recharge areas to discharge areas, 
(2) relative residence time of water along a section, (3) types of flow systems-local in contrast to regional, and (4) potential ground-water contributing area.

\section{HYDROLOGIC CONTROLS}

The dominant hydrologic control on each flow system under both aquifer-system geometries is topography-this includes the overall topographic setting or factors such as altitude and topographic relief. The relation between land-surface altitude and water-level altitude described previously (table $2 B$ ) suggests strong hydrologic control. The relation between relief (differences in land-surface altitude over selected horizontal dimensions) and hydrologic control is described in the following paragraphs. The type of control, in turn, is affected by the particular topographic setting; this aspect is best shown by the flow system for section $E$ $E^{\prime}$, South King County (plate 1). The eastern part of this section starts at a ground-water divide in the uplands at an altitude of about $500 \mathrm{ft}$ and slopes downward to a valley at an altitude of about $80 \mathrm{ft}$; this part of the section is bounded on the west by a bluff. Except near the bluff, irrespective of the subsurface conductivity distribution, the flow system in the glacial and interglacial deposits in this area is typified by small vertical gradients and predominantly horizontal ground-water flow. However, near the bluff, vertical ground-water flow predominates in the upper part of the system. The western part of the section is defined by an upland about $5 \mathrm{mi}$ wide that is bounded on both sides by steep bluffs. The flow system in this area is typified by predominantly vertical ground-water flow. As for the eastern area, the presence of bluffs (large topographic relief) provides for strong topographic control.

Within the flat central part of section $E-E^{\prime}$ is a broad alluvial valley. Along this feature, the lateral gradients are small, and ground-water flow is upward throughout most of the vertical section; however, downward flow is calculated below the topographic high located near the center of the valley. (The small lateral gradients and upward flow in the alluvial valleys were described earlier on the basis of the generalized waterlevel configurations.) Topography provides minimal control on the flow system in the alluvial valley deposits, especially when compared with the other type of deposits.

The effective length and altitude change between a topographic high or ground-water divide and the principal discharge location for the aquifer system (saltwater bodies or major river valley) appears to define the topographic control on the flow system. On the basis of the horizontal grid dimensions for all sections (table 10), a topographic high needs to extend over at least 2,000 to
$5,000 \mathrm{ft}$ and have vertical relief on the order of $100 \mathrm{ft}$ or more to provide strong control on the ground-water flow system.

The next important control on the flow system is the presence of saltwater bodies; this includes the configuration of the shoreline and the depth of the saltwater body. All flow systems terminate at a freshwater-saltwater boundary except where they terminate at the major rivers situated in the broad alluvial valleys, at bluffs in the upper units, or at bedrock. Thus, the hydraulic-head distribution within each section is partly controlled by the saltwater boundary (for example, see section $C-C^{\prime}$, plate 1 ). Topographic control interacts with the saltwater control by affecting the type of flow system present near saltwater. For example, if there is steep topography near saltwater, the gradients generally will be large (see section $E-E^{\prime}$, plate 1); whereas if the topography is relatively flat near saltwater, head gradients generally will be small (see section $F-F^{\prime}$, plate 1). The latter example is always true for the alluvial deposits in the large alluvial valleys near the coastline.

Depending on the particular location, the other important hydrologic controls on the flow system are (1) the presence, extent, and location of the fine-grained (clay dominated), generally interglacial units, and (2) the configuration or geometry of the basement confining unit. The fine-grained units generally have conductivities several orders of magnitude smaller than the other units (table 3), and the tops of these units generally are at an altitude of -50 to $200 \mathrm{ft}$. If a fine-grained unit is present above sea level, it will not only impede the vertical movement of water to the deeper units, but also the top altitude of this unit at the terminus of a flowpath will be a major control on the upper part of the flow system. If flowpaths are relatively short, on the order of 1 to $4 \mathrm{mi}$, much of the recharge will discharge above sea level, leaving smaller quantities of water available to move to deeper units, and saltwater will provide the greatest control on the deeper system. Saltwater also may not be in direct hydraulic connection with the upper system, that part of the system overlying these fine-grained deposits. For example, layer 2 (aq1) at the east end of section $A-A^{\prime}$ (detailed geometry on plate 1) typifies the above setting where layer 3 (nonaq1) (plate 1; table 9) provides the above-sea-level control. For the case where the top of the fine-grained unit is below sea level, this allows for (1) saltwater control for the upper flow system, which may restrict horizontal freshwater flow; and (2) as much as $100 \mathrm{ft}$ of additional hydraulic-head difference in the upper part of the flow system, which in turn, can provide for more vertical flow. An example of this setting is shown by layer 3 (aq1) at the east end of section $B-B^{\prime}$ (detailed 
geometry on plate 1; table 9). The fine-grained units are present as alternating sequences within the glacial and interglacial deposits, and thus the previous discussions apply to these deposits and not to the alluvial deposits.

The geometry of the basement confining unit for each section (see plate 1 ) provides a wide range of control on the flow system. The most obvious control is on the total thickness of the unconsolidated deposits; where the top of the basement confining unit is deep, the unconsolidated deposits are thick, and thus, the ability of the aquifer system to store and transmit water is increased; but where the top of the basement confining unit is shallow, the aquifer system is thin and is truncated where the basement confining unit crops out. Another control of the basement confining unit is by the geometry of the bedrock-bounded valleys in the uplands and mountainous areas. The location and extent of these valleys control the amount of unconsolidated deposits in them; thus, the extent of the aquifer system in these valleys is controlled by the basement confining unit.

The model results for the two Bainbridge Island sections, $C-C^{\prime}$ and $D-D^{\prime}$, show two aspects of the control of the basement confining unit. For the flow system along section $C-C^{\prime}$ (plate 1 ), the basement confining unit does not affect the flow system, at least under the modeling strategies used because of the presence of saltwater boundaries and a deep top of basement confining unit. For the flow system along section $D-D^{\prime}$ (plate 1 ), the basement confining unit provides a boundary that truncates the flow system, which results in ground water flowing upward. (The truncation of a flow system by the basement confining unit also is shown for section $A-A^{\prime}$; see plate 1$)$. The calculated vertical hydraulichead distributions for sections $B-B^{\prime}, E-E^{\prime}$, and $F-F^{\prime}$ (plate 1) show the transition of control from the basement confining unit to saltwater boundaries.

Interpretation of the hydrologic control of the basement confining unit and other factors on the basis of modeling results needs to be done carefully. For example, on the west end of section $E-E^{\prime}$ (plate 1), the basement confining unit has a high situated below a topographic high (upland), and it appears that the ground-water divide in the deeper system in this area, at least in part, is caused by the geometry of the basement confining unit. However, results of additional model simulations for this section indicate that the divide is controlled by topography. For these simulations (not shown), the deepest part of the basement confining unit below the alluvial valley was assumed to extend westward to the end of the section; that is, the model grid system was reconstructed such that the basement confining unit high was eliminated, and the unconsolidated layers (units) were extended to the western end. Using this hypothesized geometry, the model-calculated flow system was nearly identical to that shown on plate 1, and the location of the groundwater divide in the deeper system did not change, showing how the topographic effects can propagate deep into the flow system.

\section{HYDRAULIC-HEAD GRADIENTS}

Horizontal and vertical hydraulic-head gradients in the aquifer system are described on the basis of results of the model for section $E-E^{\prime}$ because of the range in aquifer-system geometries in this section. Gradients at the eastern, upgradient end of this section are small, predominantly horizontal and vertically downward. Horizontal gradients average about $0.008 \mathrm{ft} / \mathrm{ft}$ in this part of the section, and the vertical gradients range from about $0.18 \mathrm{ft} / \mathrm{ft}$ near the eastern part to about $0.02 \mathrm{ft} / \mathrm{ft}$ in the central part of the section near the alluvial valley. These gradients appear to be typical for this type of setting-a recharge area with relatively small topographic relief, reasonable lateral continuity of units, long distance to major discharge area (alluvial valley), and flowpaths on the order of 5 to $7 \mathrm{mi}$. In the western end of the section, vertical gradients generally are larger than in the eastern part, averaging about $0.36 \mathrm{ft} / \mathrm{ft}$, and horizontal gradients range from about $0.002 \mathrm{ft} / \mathrm{ft}$ in the upper system away from the bluffs to about $0.09 \mathrm{ft} / \mathrm{ft}$ near the bluffs. These gradients in the western end of the section appear to be typical of this type of setting-relatively large topographic relief, a confining fine-grained unit that crops out above sea level on the bluff, and a short distance to the major discharge areas (alluvial valley and saltwater body).

Large or steep gradients near bluffs, described previously in the "Ground-Water Flow System" section, are clearly shown on plate 1 ; the magnitude of these gradients generally will correspond to the altitude difference between the top of a bluff (several 1,000 ft inland) to the base level of the discharge area, either sea level or the floor of the broad alluvial valleys. Locally, the largest vertical hydraulic-head gradients occur between the upper system and the first major fine-grained unit under both the detailed and aggregated section geometries.

The hydraulic-head gradients in the alluvial valley deposits generally are smaller than the gradients in the other deposits. Horizontal gradients in the alluvial valley are on the order of $0.0007 \mathrm{ft} / \mathrm{ft}$, and vertical gradients are about $0.01 \mathrm{ft} / \mathrm{ft}$; these small gradients indicate the effects of relatively flat topography and large hydraulic conductivity. Small gradients also are exhibited in areas with thick, coarse-grained recessional 
outwash deposits such as south-central and western Pierce County (fig. 10).

\section{GROUND-WATER FLOWPATHS AND TRAVELTIMES}

Under the current pumping conditions, lengths of ground-water flowpaths range from about $1,000 \mathrm{ft}$ in the upper parts of the aquifer system to about $15 \mathrm{mi}$ in the deeper parts of the flow system (plate 1 and fig. 10). The hydraulic-head distributions on plate 1 together with the water levels shown in figure 10 (ignoring very localized flowpaths on the order of several hundreds of feet) indicate that most flowpaths generally range from 2 to $7 \mathrm{mi}$; maximum lengths of flowpaths within the Puget Sound aquifer system are on the order of $20 \mathrm{mi}$ in southeast Pierce County (see fig. 10). Flowpaths within the alluvial valley deposits generally are on the order of 0.5 to $4 \mathrm{mi}$.

Ages of seven ground-water samples collected in 1990 were determined from tritium concentrations to estimate residence times in the upper part of the flow system and to assess the relation between the residence times and potential flowpath traveltimes calculated from information from model simulation. Five of the sample points were on or near section $E-E^{\prime}$ (see plate 1); the following analysis will discuss information for these points.

Large concentrations of tritium in ground water indicate that the water is less than about 40 years old; it has entered and moved in the aquifer system after about the beginning of 1953 . Tritium concentrations less than about 0.1 (in tritium units) would indicate that the water is older than 50 years. The estimates of ground-water ages are based on a monthly concentration of tritium (fallout) (H.H. Bauer, U.S. Geological Survey, written commun., 1994), the decay of tritium, monthly precipitation quantities, and a piston-flow analog (Marshall and Holmes, 1979; Plummer and others, 1993); thus, the estimates do not account for possible mixing of water of different ages. Using this information, the ages of the ground water for each sample were estimated as follows:

\begin{tabular}{ccl}
\hline $\begin{array}{l}\text { Sample point } \\
\text { (plate 1) }\end{array}$ & $\begin{array}{l}\text { Tritium concentration } \\
\text { (tritium units) }\end{array}$ & \multicolumn{1}{c}{$\begin{array}{l}\text { Age } \\
\text { (years) }\end{array}$} \\
\hline p1 & 2.6 & $37-38$ \\
p2 & 16.0 & $30-34,16-19,13-14$ \\
p3 & 6.8 & $35-38,8-9$ \\
p4 & 10.1 & $36-38,33-34,9-12$ \\
p5 & .1 & older than 50 \\
\hline
\end{tabular}

The range in ages is due to the variability of both the tritium concentrations and the monthly precipitation. As shown in the preceding table, the water at four of the five sample points is less than 40 years old.
With a known or estimated flowpath, an effective velocity can also be calculated for each of the points for each of the age groups. However, for this analysis, velocities were estimated using the tritium information for only points $\mathrm{p} 4$ and $\mathrm{p} 5$ because the flowpaths could be estimated with some degree of reliability-the paths generally are vertical from the land surface to the well intake. Particle tracking, described in the following paragraphs, showed that there are many potential flowpaths to points $\mathrm{p} 1, \mathrm{p} 2$, and $\mathrm{p} 3$, and thus, ground-water velocities were not calculated for these points.

Flowpaths were calculated using the particle-tracking program MODPATH (Pollock, 1989). Particles were tracked both forward and backward. For forward tracking, three particles per cell were placed along a line that spanned the potential recharge area for points $p 1$, $\mathrm{p} 2$, and $\mathrm{p} 3$; this line extended from the eastern end of the section to the first major bluff, for a total of 26 cells (see plate 1). The particles were placed at the upper surface of these 26 cells, and the paths and traveltimes were calculated. For the backward tracking, flowpaths were calculated by placing particles in each of the five cells from which the wells that were sampled withdrew water. To estimate variations in flowpaths and traveltimes, several schemes of particle placement and number of particles were used in the backtracking. The traveltimes and velocities discussed in the following paragraphs do not account for movement through the unsaturated zone.

Although the overall ground-water flow is both upward and horizontal in the alluvial valley, the location of sample point $\mathrm{p} 4$ is near a locally downward flow area where the flow is controlled by a topographic high. To obtain a maximum range in velocities, ages of 38 and 9 years were used in the calculations. Assuming no mixing and that the sampled parcel of water at point p4 moved from the land surface downward to a depth of $134 \mathrm{ft}$ (the depth of the well), the range in effective velocities was from 0.01 to $0.04 \mathrm{ft} / \mathrm{d}$. Backward tracking resulted in all particles following the same flowpath with a traveltime of about 62 years; for a depth of $134 \mathrm{ft}$, 62 years corresponds to a velocity of about $0.006 \mathrm{ft} / \mathrm{d}$. For point $\mathrm{p} 5$, the effective maximum velocity (based on an age of 50 years) from the land surface to the bottom of the well would be about $0.017 \mathrm{ft} / \mathrm{d}$. Particle backtracking resulted in a large range in traveltimes, from 30 to 335 years. Backtracking 27 particles showed 67 percent of the particles having traveltimes between about 30 and 80 years, and backtracking 8 particles resulted in 75 percent of the particles having traveltimes between 30 and 70 years. Using 30 years and 80 years gave a potential range in velocity of 0.011 to $0.028 \mathrm{ft} / \mathrm{d}$. Thus for sample points $\mathrm{p} 4$ and $\mathrm{p} 5$, the model results and age dating qualitatively support the 
conceptual flow model and the overall residence times in these two locations.

The age of the water at sample point p1 was about 37 to 38 years. Backtracking gave traveltimes that ranged between 6 and 790 years; the large range was due to the different flowpaths that the particles followed. Although the particles followed different flowpaths, the end of each flowpath was in the same cell. For the forward tracking, from the top of the water table, additional potential flowpaths and traveltimes were calculated. The age dating suggests that the sampled water followed one of the shorter possible flowpaths. The age of the sampled water at point $\mathrm{p} 2$ probably ranged from 13 to 34 years. Backtracking gave traveltimes that ranged from about 855 to 1,065 years. Similar to point p1, some backtracked flowpaths were different, but the end of the paths were the same. Each of these paths had the particles moving quickly to a water-table cell and then long paths that backtracked upgradient along a section of the water table. Forward tracking showed that the particles in any of these watertable cells could move to point p2. Traveltimes for forward tracking ranged from 5 to 870 years, depending on the water-table cell that a particle originated in. Again, the tritium-dated age of the sampled water at point $\mathrm{p} 2$ suggests that it followed one of the shorter flowpaths calculated with MODPATH. The relatively narrow ranges in ages for the samples as compared to the particle traveltime further suggest that the assumption of piston flow with little mixing may be reasonable.

The analysis for point $\mathrm{p} 3$ is slightly different because of the thickness of the unit that the well is completed in. A particle at the bottom of the unit can follow a much different path than a particle at the top of the unit. There were two estimated age ranges for the sample from point $\mathrm{p} 3-35$ to 38 and 8 to 9 years. Particles backtracked showed a wide range in flowpaths and thus traveltimes. The traveltimes ranged from 15 to 900 years. Particles originating near the upper part of the unit had the shortest flowpaths and traveltimes. Forward-tracked particles had an even larger range in potential flowpaths and traveltimes. However, similar to backtracking, several short paths had traveltimes within the two age ranges estimated from the tritium information. This suggests that the sampled water followed one of the shorter possible flowpaths and that complete mixing over the thickness of the aquifer unit was not achieved at this location in the flow system.

The ages based on the tritium information and the flowpaths and traveltimes calculated by MODPATH indicate the overall reasonableness of the flow system calculated by the flow model; the ages were within the range of the calculated traveltimes. The analysis also indicates that the shorter calculated flowpaths were more representative than the longer paths of the tritium-estimated ground-water age. The shorter flowpaths also were conceptually more simple and smooth. The paths tracked forward displayed a broader range in lengths and traveltimes but provide a good representation of how water moves from the top of the water table to some point in the system. Additionally, had extensive mixing of ground water occurred, the flowpaths calculated with MODPATH suggest that the resulting age in most cases should have been older than the sampled water. Again, this indicates less mixing along the short flowpaths.

\section{EVALUATION OF THE FLOW SYSTEMS}

The flow systems calculated using both the detailed and aggregated system geometries generally are similar to each other and to the system suggested by figure 10 . Thus, the results of model simulations indicate the potential usefulness of the regional water-level configurations (fig. 10), and they also allow for a more detailed description of the regional flow system and of its controls based on the local sectional information. Differences between calculated flow systems for the two geometries are most pronounced in areas with large downward gradients in the upper part of the aquifer system. In these areas, using the aggregated geometry, the model calculated a predominantly horizontal flow system because there is only one layer (unit) present. However, the similarities indicate that (1) the major controls previously described are represented under both geometries, (2) the fine-grained unit is an important control, and (3) the detailed geometry does not necessarily need to be defined to describe, on a regional basis, the ground-water flow system. Indeed, the calculated flow system (including the location and depth of the saltwater interface) for section $B-B^{\prime}$ under both aquifer-system geometries generally is similar to that calculated by Sapik and others (1988, plate 4) using a detailed three-dimensional model of ground-water flow.

A large part of the deposits present in the Puget Sound Lowland below the first major fine-grained (clayey) unit occurs below sea level. Division of the deeper system into layers or zones for the construction of the models, although somewhat arbitrary, was based on an assumed practical depth for future ground-water exploration, an assumption of small gradients, and the concept that the movement of water decreases with depth in the system. In some areas, this division would have natural boundaries that correspond to deeply buried, extensive, fine-grained units such as the Puyallup Formation (fig. $5 \mathrm{C}$ ). On the basis of the model results, the head distribution in these deeper deposits is not as 
affected by the presence of intercalated fine-grained deposits as those deposits above the clay unit. The deeper parts of these deposits also are typified by a slower and less-active flow system. Large vertical-head changes at depth (the most likely effect of areally extensive fine-grained deposits) have not been identified. However, there are factors that are not conducive for these types of head changes, including the type of flow system present, the hydrologic controls on this deeper system, and the lack of stresses.

The surficial (generally till) fine-grained layer was combined with the upper aquifer layer for the model simulations using the aggregated geometry. Although this unit provides strong control to the ground-water system by limiting recharge (and, thus, ground-water availability), its hydraulic characteristics do not appear to provide strong control on the flow systems. This is because on a regional basis (1) the unit varies areally from unsaturated to seasonally saturated to saturated, (2) its hydraulic conductivity generally is much larger than that of the fine-grained silty-to-clayey units, and (3) its thickness generally is small in comparison to the total thickness of the units aggregated in the upper layer. However, the surficial unit probably should be assessed as a separate unit on a regional basis to address ground-water availability or contaminant transport because (1) it exerts strong control on recharge, (2) its conductivity is much smaller than the underlying aquifers, and (3) where it is least seasonally saturated, it can affect the flow system in the underlying aquifer.

Thus, the presence and hydrologic control of the fine-grained units probably result in a flow system in the glacial and interglacial deposits typified by (1) an upper system that is complex, has both small and large hydraulic-head gradients, and is principally controlled by topography and discharge altitude (sea level or major alluvial valley); and (2) a lower system that is less complex, has small head gradients, is dominated by horizontal flow, and is principally controlled by saltwater and the basement confining unit. Variations to these overall patterns will be due to extension of the topographic control to deeper units, lengths of flowpaths, and local aquifer-system geometry.

The major alluvial valleys are glaciofluvial carved channels that have been filled with large amounts of alluvial deposits. These valleys generally are continuous topographic, low-altitude features compared to the surrounding glacial-interglacial deposits and represent major ground-water discharge areas (see for example section $E-E^{\prime}$, plate 1 ). These valleys provide regional hydrologic control to the flow systems in the glacial and interglacial sequence of deposits; the alluvial deposits generally are distinct and mappable from the glacial- interglacial deposits and may be in contact with as many as four local glacial-interglacial hydrologic units.

As discussed previously, the combination of topographic control, geometry of the basement confining unit, configuration of the saltwater shoreline, large depths of the saltwater bodies (several hundreds of feet), and the location and size of the major broad alluvial valleys results in a regional aquifer system dominated by short flowpaths and isolated flow systems; that is, there is no regional flow system, only an adjacent series of somewhat isolated subregional flow systems. Because of these factors and the control of the fine-grained deposits within the glacial and interglacial sequence of hydrogeologic units, the aquifer system has a decreased ability to transmit water to the deeper parts of the system and there generally are only small contributing areas of recharge. Together, these factors potentially interact to limit ground-water availability and increase the potential for saltwater intrusion in some areas.

\section{CALCULATED WATER-BUDGET COMPONENTS}

The water-budget components for each of the six cross-section models are presented in table 12. The water budget for each section, and thus the quantity of water moving through each section, is a function of the recharge, length of section (flowpath) or size of contributing area, discharge locations, and aquifer-system geometry. This section of the report will briefly describe these functions on the basis of model results. The total ground-water flow (in terms of unit flow quantities per mile of section) and the potential hydrologic importance of this measure are first described. The partitioning of the total flow into the discharge components is then described. Next, the unit recharge values are compared to streamflow information previously presented (table 7) and to low-flow values for the Puget Sound region. Physical factors affecting the partitioning of the total flow (recharge) to discharge components are then discussed. Next, the partitioning of flow to saltwater discharge for the model sections and for the Puget Sound Lowland is discussed. Last, the quantity of ground water moving into the deeper part of the aquifer system is described; the quantity is of interest to water-resource planners because the upper part of the system is more vulnerable to contamination, is already being utilized in many areas, and pumping from it can more readily affect streamflow.

\section{TOTAL GROUND-WATER FLOW}

The total ground-water flow in each section ranges from 0.12 to $0.54\left(\mathrm{ft}^{3} / \mathrm{s}\right) / \mathrm{mi}$ (table 12). The largest flows 


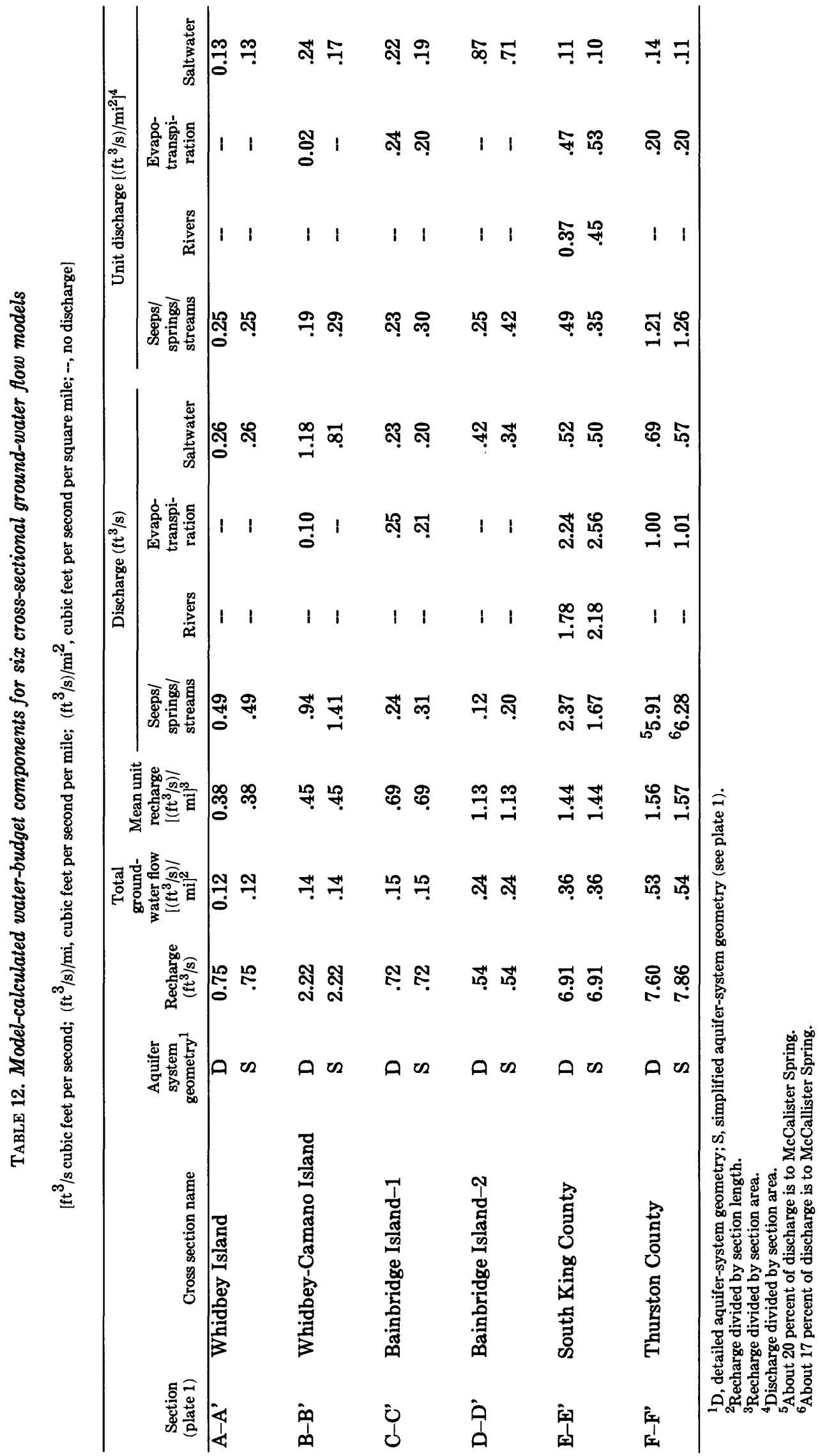


are in sections $E-E^{\prime}$ and $F-F^{\prime}$, both of which are long sections located in areas with relatively large quantities of recharge (fig. 13, tables 11 and 12). Section $B-B^{\prime}$ also is long (15.62 mi, table 10), but because it is located in an area with small quantities of recharge, the total flow is small, $0.14\left(\mathrm{ft}^{3} / \mathrm{s}\right) / \mathrm{mi}$ (fig. 13, tables 11 and 12$)$. For the case of section $D-D^{\prime}$, the average recharge (about $17 \mathrm{in} / \mathrm{yr}$ ) is about $7 \mathrm{in} / \mathrm{yr}$ larger than the average for section $B-B^{\prime}$, but because the section is short $(2.29 \mathrm{mi})$, the total flow $\left[0.24\left(\mathrm{ft}^{3} / \mathrm{s}\right) / \mathrm{mi}\right]$ is intermediate in the calculated range. Therefore, to sustain large flows along a flowpath (which can provide for ground-water availability because it is indicative of, or a measure of, a larger ground-water contributing area), a long flowpath and large quantities of recharge are needed.

The importance of the total ground-water flow as a hydrologic measure of the integration of flowpath length and recharge quantities can be further shown by several examples. As shown previously, section $D-D^{\prime}$ is in an area with larger recharge quantities than section $B-B^{\prime}$, but the actual recharge to section $D-D^{\prime}$ is much less than that to section $B-B^{\prime}$. In contrast, the unit recharge of section $B-B^{\prime}$ is much less than that to section $D-D^{\prime}$. Thus, recharge rates and unit recharge would suggest different hydrologic budgets when these two sections are compared-discharge to seeps and saltwater for section $D-D^{\prime}$ is less than that for section $B-B^{\prime}$, whereas unit discharge to seeps and saltwater for section $D-D^{\prime}$ is greater than that for section $B-B^{\prime}$. However, for assessing the quantity of water, the total flow (a unit measure) indicates the actual quantity of water that moves through a section or flowpath. Thus, although section $B-B^{\prime}$ has much greater recharge than section $D-D^{\prime}$, there is about $0.10\left(\mathrm{ft}^{3} / \mathrm{s}\right) / \mathrm{mi}$ less water moving through it (table 12); that is, excluding storage, there generally would be less water available for capture by wells when the total flow is small.

\section{PARTITIONING OF GROUND-WATER FLOW}

Under the various physical settings and aquifer-system geometries, the part of the total flow that discharges to seeps, to evapotranspiration, to major rivers, and to saltwater bodies can be characterized on the basis of the model results (table 12). The relations between the partitioning allow for an initial assessment of the effects of the physical settings and aquifer-system geometries present in the sections. The percentage of total flow that discharges to seeps ranges from about 22 to 81 percent and that which discharges to saltwater ranges from about 7 to 78 percent. About 24 to 26 percent of the ground-water flow in section $E-E^{\prime}$ discharges to a major river. The large range in these percentages, as much as 71 percent, is due to the complex interaction of the hydrologic controls described in the previous section and further shows the large variability of flow systems in the Puget Sound Lowland.

The total ground-water flows just described correspond to unit recharge values under steady-state conditions that range from 0.38 to $1.57\left(\mathrm{ft}^{3} / \mathrm{s}\right) / \mathrm{mi}^{2}$ (table 12). The mean annual unit recharge values should be within the range of the median 7-day unit low-flow values (7du) for the seven basins (table 7) discussed previously and less than the mean annual unit streamflow values for those basins because flow in both the sections and the basins was assumed to be representative of the flow for much of the low-lying parts of the Puget Sound Lowland. Additionally, the unit recharge values also should be in the range of the observed 7du for the Puget Sound Lowland. As described previously, low-flow values relate to basin area, recharge, surficial geology, and physical setting. In turn, recharge supports the low flows (and annual flows), and the relation between recharge and low flows indicates both the variability in those relations and the areal representativeness of the recharge for the low-lying areas. The recharge values are both smaller and larger than the median $7 \mathrm{du}$, and smaller than the mean annual unit flows of the selected basins (table 7). These values also are larger than the 25th percentile and smaller than the 80th percentile of the 7du for the Puget Sound region (Hidaka, 1973). The mean unit recharge for sections $A-A^{\prime}$ through $D-D^{\prime}$ are between the 25 th and 50 th $7 \mathrm{du}$ percentiles, and values for $E-E^{\prime}$ and $F-F^{\prime}$ are between the 75th and 80th $7 \mathrm{du}$ percentiles. The preceding comparison indicates that not only is the recharge representative but also that the partitioning (and its variability) of the recharge into discharge components is representative for the area. For this partitioning, a part of the total flow for all sections discharges to seeps and to saltwater (table 12), and thus, a part of the total flow is not available to support streamflow.

\section{HYDROLOGIC GONTROLS ON DISGHARGE}

Topographic relief is a major hydrologic control and partly controls the part of the total flow that supports streamflow. In turn, drainage networks are related to topography. Areas with relatively small topographic relief and small quantities of precipitation-"the water input to an area which provides the major driving force in the development of morphology" (Beven and others, 1988; p. 353)-are not conducive for establishment of well-developed drainage networks. This is especially true of the young landscape in much of the Puget Sound Lowland and also in areas with large quantities of precipitation and thick recessional outwash deposits (small runoff and erosion); for example, south-central 
Pierce County (figs. 6 and 13). Therefore, if short flowpaths are present in these types of areas, much of the ground-water flow should discharge to seeps and saltwater. For example, about 65 percent of the recharge in section $A-A^{\prime}$ discharges to seeps (mainly along bluffs), and 35 percent discharges to saltwater; this indicates that ground water may provide only small quantities of water to streams in this type of physical setting. With long flowpaths, variable relief, and large quantities of precipitation, ground water can provide a larger part of the flow in a stream. The physical setting of the outflow location of a basin under the latter conditions can also affect ground-water flow to a stream. For example, Burley Creek (table 7, fig. 11) has variable relief and large quantities of precipitation. However, because the outflow location is at saltwater in an area of small relief, flowpaths do not need to be as long, and most of the ground-water recharge discharges to the stream. For this setting, subregional flow also contributes to streamflow.

The quantities of ground water available to discharge to saltwater under longer flowpaths, variable relief, and large quantities of precipitation depend on the presence or absence of topographic features such as broad alluvial valleys or wide ( 2 to $5 \mathrm{mi}$ ) topographic highs, which control the flow system. Such features tend to limit discharge to saltwater. For example, only about 8 percent of the recharge along section $E-E^{\prime}$ discharges to saltwater because of the presence and subsequent hydrologic control of these features (plate 1, table 12). Additionally, section $F-F^{\prime}$, which has a similar section length and recharge quantities as those of section $E-E^{\prime}$, discharges about 9 percent of its recharge to saltwater. The similarity in percentage of water discharging to saltwater is because the flat alluvial valley along section $F-F^{\prime}$ is near the terminus of the section, and the valley's trend is colinear with the flowpath; the valley provides both local hydrologic control (plate 1) and regional control (fig. 10). Therefore, even with long flowpaths, the topographic control results in less than 10 percent of the recharge discharging to saltwater. A further comparison of how the physical setting may affect discharge is provided by the model results from section $F-F^{\prime}$ and by information for Burley Creek. The overall physical setting and the unit recharge value for section $F-F^{\prime}$ are similar to those for the Burley Creek Basin (fig. 11, table 7), but there are more relief and topographic features in section $F-F^{\prime}$. Thus, the unit discharge for seeps for section $F-F^{\prime}$ (table 12) should be similar to the 7du for Burley Creek (table 7). Comparison of these values shows that the large $7 \mathrm{du}$ for Burley Creek is similar to the unit discharge to seeps for section $F-F^{\prime}$.
The water budgets for each model (table 12) generally are similar under both the detailed and simplified aquifer-system geometries, including sections $A-A^{\prime}$ and $B-B^{\prime}$, for which the aggregation of units was most severely tested. The differences in the water budgets are due to the effects of a predominant flow system that is calculated for the upper part of the aquifer system using the aggregated geometry. This flow generally allows for increased discharge and decreased vertical movement of water to the deeper system. However, the differences are much less than the total range in estimated discharge values for the sections and typically are less than the probable error associated with values estimated using standard field methods. Indeed, except for major springs and streamflow, discharge to seeps and saltwater is difficult to measure and generally is estimated with water-budget techniques.

The largest calculated difference in unit discharge to saltwater between the aquifer-system geometries occurred for the shortest section, $D-D^{\prime}$ $\left[0.17\left(\mathrm{ft}^{3} / \mathrm{s}\right) / \mathrm{mi}^{2}\right]$, where the effects of a lateral flow system calculated using the simplified geometry are the greatest. Note that section $D-D^{\prime}$ also has the largest unit discharge to saltwater because of aquifer-system geometry. Sections $B-B^{\prime}$ and $E-E^{\prime}$ have the most complex aquifer-system geometries, variable hydrologic controls, and subsequent complex flow systems. The results of the models for these two sections indicate about a 31- and 2-percent difference in discharge to saltwater, respectively, between the simulations using the two different geometries. Again, these differences would be less than the potential error in estimates derived using field and other techniques, and the 31percent difference occurred for the most severe test of aggregation of units.

Therefore, irrespective of aquifer-system geometry, the model's results indicate the range in values of recharge and discharge that probably can be expected in the Puget Sound Lowland. Additionally, the range in and partitioning of discharge to seeps, saltwater bodies, and rivers may be considered representative of the region. Although major rivers were only present in sections $E-E^{\prime}$ and $F-F^{\prime}$, the water-level configurations (table 2) and the overall configuration of the major alluvial valleys (fig. 6) indicate that the partitioning of discharge to rivers is representative. The partitioning is strongly affected by the hydrologic controls previously described. Of particular interest is the fact that, excluding section $D-D^{\prime}$, the unit discharge (table 12) to saltwater bodies is similar for most sections. 


\section{DISCHARGE TO SALTWATER BODIES}

The fresh ground-water discharge to saltwater bodies is important because it may locally affect the characteristics of the Puget Sound (Puget Sound Water Quality Authority, 1992), the major saltwater body in the study area. Therefore, using the results of the models, which are assumed to be regionally representative, estimates of the projected range in this discharge are described in the following paragraphs. Excluding section $D-D^{\prime}$, the model results indicate that about 7 to a maximum of 53 percent of the recharge in the Puget Sound Lowland discharges to saltwater. On the basis of these percentages and the regional estimate of recharge $\left(14,510 \mathrm{ft}^{3} / \mathrm{s}\right)$, from 1,015 to $7,690 \mathrm{ft}^{3} / \mathrm{s}$ of ground water may discharge to saltwater. Unit discharge to saltwater bodies ranges from about 0.10 to $0.24\left(\mathrm{ft}^{3} / \mathrm{s}\right) / \mathrm{mi}^{2}$. Using these unit values and a total area of $7,300 \mathrm{mi}^{2}$, estimated discharge would range from about 730 to $1,752 \mathrm{ft}^{3} / \mathrm{s}$. The modelcalculated range in discharge per mile of shoreline varies from about 0.04 to $0.37\left(\mathrm{ft}^{3} / \mathrm{s}\right) / \mathrm{mi}$. Using a total shoreline length of $2,250 \mathrm{mi}$, discharge to saltwater bodies would range from about 90 to $832 \mathrm{ft}^{3} / \mathrm{s}$. Except for the last values, these estimated ranges probably are too large because much of the recharge in the upland and mountainous areas of the Puget Sound Lowland (where recharge is greatest, see fig. 13) discharges within local flow systems. That is, the total or effective area contributing discharge to saltwater bodies is less than that used for the previous estimates, and thus, the recharge value and the total area used to estimate these ranges should be smaller.

On the basis of generalized water-level configuration (fig. 10) and assuming that (1) area and recharge vary linearly (that is, a reduction in area is equivalent to the same reduction in recharge) and (2) water that moves to the major alluvial valleys does not discharge to saltwater, a reduction in area of 80 percent was estimated. This reduction results in an area of about $1,460 \mathrm{mi}^{2}$ and a mean annual recharge of about $2,902 \mathrm{ft}^{3} / \mathrm{s}$. These area and recharge values correspond to ranges in saltwater discharge values of 146 to 350 and 203 to $1,538 \mathrm{ft}^{3} / \mathrm{s}$, respectively; again, the latter range may be too large. Together, the ranges suggest that discharge to saltwater bodies ranges from about 100 to $1,000 \mathrm{ft}^{3} / \mathrm{s}$.

\section{VERTICAL MOVEMENT OF WATER}

The upper part of the aquifer system generally consists of all the units above the first major fine-grained unit and generally corresponds to a water table or semiconfined system. The deeper part of the aquifer system is the remaining part of the Quaternary deposits below the fine-grained aggregation unit. On the basis of model results for both geometries (plate 1), the percentage of the total recharge that moves either downward to the units underlying or upward to the units overlying the fine-grained unit was calculated. In addition, water moving only through the fine-grained aggregation unit was calculated. Percentage of total recharge is discussed so that information from sections can be compared and because of the large range in recharge estimates for both the models and the Puget Sound Lowland. Sections $A-A^{\prime}$ and $B-B^{\prime}$ do not have the latter values for the simplified geometry because a deeper fine-grained unit was used in the testing; however, values were calculated for the detailed geometry.

The calculated percentage of recharge that moves from the upper part of the aquifer system into the deeper part varies widely, from 1 percent for section $A$ $A^{\prime}$ under the simplified geometry to 80 percent for section $F-F^{\prime}$ under the detailed geometry (table 13). The large range in values further indicates the variability of flow systems in the Puget Sound Lowland. The largest values (80 percent, section $F-F^{\prime}$ and 78 percent, section $\left.D-D^{\prime}\right)$ are due to different hydrologic controls-the first is due to the absence of the fine-grained aggregation unit (nonaq) over part of section $F-F^{\prime}$, and the second is due to the overall aquifer-system geometry of section $D-D^{\prime}$. The control for the first case is also represented in the much smaller quantity that moves through nonaq (table 13). Except for section $E-E^{\prime}$, a smaller percentage of recharge moves to the deeper system under the simplified geometry than under the detailed geometry because increased lateral flow is calculated in the upper system. The increased lateral flow for section $E-E^{\prime}$ corresponds to lower calculated heads in the long, eastern part of the section, and thus, less water moves to streams (table 12), with a corresponding increase in water that moves to the deeper system.

The percentage of recharge that moves upward from the deeper system underlying the aggregation unit to the shallow system also varies considerably, but with a smaller range of values than that moving downward (table 13). The percentage ranged from 0 for section $A$ $A^{\prime}$ to 43 percent for section $E-E^{\prime}$, both values being for the simplified geometry. Only sections $E-E^{\prime}$ and $F-F^{\prime}$ had a relatively large percentage of water moving upward because of the hydrologic control of topographic features-the alluvial valley for section $E-E^{\prime}$ and the flat topography near the Nisqually River, which is located near the shoreline at the end of a long flowpath, for section $F-F^{\prime}$ (plate 1).

The percentage of recharge that moved through the fine-grained aggregation unit is dependent upon the lateral extent of the unit; if the unit is present throughout a section, then all of the water must move through it. The differences in the downward percentages 
TABLE 13. Model-calculated percentage of recharge that moves downward from the identified unit to underlying units and moves upward from below the identified unit to overlying units

\begin{tabular}{|c|c|c|c|c|c|c|c|}
\hline \multirow[b]{2}{*}{$\begin{array}{l}\text { Section } \\
\text { (plate 1) }\end{array}$} & \multirow[b]{2}{*}{$\begin{array}{l}\text { Aquifer- } \\
\text { system } \\
\text { geometry } 1\end{array}$} & \multirow[b]{2}{*}{ Unit name $^{2}$} & \multirow[b]{2}{*}{$\begin{array}{c}\text { Layer } \\
\text { number }\end{array}$} & \multicolumn{4}{|c|}{ Percentage of recharge } \\
\hline & & & & $\begin{array}{c}\text { Downward to } \\
\text { underlying } \\
\text { units }\end{array}$ & $\begin{array}{l}\text { Upward to } \\
\text { overlying units }\end{array}$ & $\begin{array}{c}\text { Downward to } \\
\text { underlying } \\
\text { unit }\end{array}$ & $\begin{array}{c}\text { Upward to } \\
\text { overlying } \\
\text { units }^{4}\end{array}$ \\
\hline \multirow[t]{3}{*}{$\overline{A-A^{\prime}}$} & $\bar{D}$ & nonaq2 & 5 & 18 & 2 & 18 & 2 \\
\hline & S & nonaq2 & 2 & 1 & 0 & 1 & 0 \\
\hline & D & nonaq1 & 3 & 60 & 0 & 60 & 0 \\
\hline \multirow[t]{3}{*}{$B-B^{\prime}$} & D & nonaq2 & 6 & 14 & 5 & 14 & 5 \\
\hline & $\mathrm{S}$ & nonaq2 & 2 & 5 & 1 & 5 & 1 \\
\hline & D & nonaq1 & 4 & 46 & 15 & 30 & 15 \\
\hline \multirow[t]{2}{*}{$C-C^{\prime}$} & D & nonaq1 & 3 & 28 & 1 & 28 & 1 \\
\hline & $\mathrm{s}$ & nonaq1 & 2 & 27 & .5 & 27 & .5 \\
\hline \multirow[t]{2}{*}{$D-D^{\prime}$} & D & nonaq1 & 3 & 78 & 5 & 78 & 5 \\
\hline & S & nonaq1 & 2 & 64 & 6 & 64 & 6 \\
\hline \multirow[t]{2}{*}{$E-E^{\prime}$} & D & nonaq2 & 7 & 41 & 33 & 39 & 0 \\
\hline & $\mathrm{s}$ & nonaq2 & 2 & 50 & 43 & 47 & 0 \\
\hline \multirow[t]{2}{*}{$F-F^{\prime}$} & D & nonaq1 & 5 & 80 & 31 & 26 & 1 \\
\hline & S & nonaq1 & 2 & 69 & 26 & 16 & 1 \\
\hline
\end{tabular}

${ }^{1} \mathrm{D}$, detailed aquifer-system geometry; $\mathrm{S}$, aggregated aquifer-system geometry (see plate 1).

${ }^{2}$ Unit names for each section are shown on plate 1.

${ }^{3}$ Layer number for each section is shown on plate 1.

${ }^{4}$ Only that part of the recharge that has moved through identified unit name/layer number.

indicate the overall effects of the continuity of units. The percentage moving upward through the finegrained unit generally is small under both geometries. The small values indicate the hydrologic control of the aquifer-system geometry and location of discharge areas. The largest percentage (15) that moved upward through the aggregation unit occurred for section $B-B^{\prime}$ (table 13); the value is larger than the other sections because the water in part of the section must move through the unit to the shallow system in order to discharge.

The differences beiween the percentage of recharge that moved either upward or downward for the two geometries ranged from 0.5 to 17 percent. These differences generally are related to the effects of the increased lateral flow calculated with the simplified geometry and to the correspondence of the increased flow to the particular aquifer-system geometry of a section. Excluding sections $A-A^{\prime}$ and $B-B^{\prime}$ where the maximum aggregation was tested, the quantity of water that moved to the deeper system changed by about 4 to 18 percent. However, the overall flow systems calculated under the simplified geometry still reasonably represent the overall flow system in a section. The maximum aggregation used in sections $A-A^{\prime}$ and $B-B^{\prime}$ does not allow for as much vertical movement of water to the deeper system as the other aggregations. Thus, the results described in this and the previous section suggest that the aggregation used for sections $C-C^{\prime}$ through $F-F^{\prime}$ is sufficient for describing ground-water flow in the region.

\section{CONGEPTUAL MODEL OF THE AQUIFER SYSTEM}

The conceptual model, based on the pertinent information previously presented and the results of the cross-sectional models of ground-water flow, includes the characteristics of the aquifer system necessary to describe ground-water flow on a regional basis. These characteristics are based on the major hydrologic controls on the ground-water system, including topography, the configuration of the basement confining unit, the presence and extent of fine-grained deposits, the configuration of saltwater bodies, the presence and extent of large alluvial valleys, the distribution of hydraulic heads within the aquifer system, and the hydraulic characteristics of the Quaternary deposits. The conceptual model is assumed to be applicable to any area within the Puget Sound Lowland. Because of the varying hydrogeologic settings within the model sections, the aggregation of units used to develop the 
regional conceptual model of ground-water flow for the Puget Sound aquifer system, although simplified, is regionally representative.

The model is applied to an area located in the FraserWhatcom Basin that was chosen because it has a unique geologic setting and because no information from the basin was used to develop the conceptual model.

\section{DESCRIPTION OF CONGEPTUAL MODEL}

The Puget Sound aquifer system comprises highly variable sequences of glacial, interglacial, and alluvial deposits. These deposits comprise four types of units-glacial and interglacial aquifers, semiconfining units, confining units, and alluvial valley aquifers. Although recessional outwash channel-fill aquifers are locally important sources of water, they are not defined as separate aquifers for this regional analysis.

The simplified conceptual model of the Puget Sound aquifer system for use in describing ground-water flow in the region thus consists of the nine alluvial valley aquifers that may or may not contain other types of deposits, a surficial semiconfining unit, and a sequence of two coarse-grained aquifers separated by a finegrained confining unit (the Fraser aquifer, the confining unit, and the Puget aquifer). The basement confining unit forms the basal and lateral boundaries of the aquifer system. The deposits that comprise the aquifer units vary from silty sand to coarse gravel and may locally contain extensive deposits or zones that are more or less productive.

The lateral extents of the surficial regional units are shown in figure 15, and the naming conventions for the units and the relations between stratigraphic units and regional hydrogeologic units are shown in figure 16 . Examples of the regional hydrogeologic units are presented in figure 17 for two of the six sections (sections $E-E^{\prime}$ and $F-F^{\prime}$ ) described previously (plate 1). Note that as previously described, there is no regional flow system in these units. The Puget Sound aquifer system thus contains numerous subregional flow systems that generally are isolated from each other under the present conditions of hydrologic stress. These flow systems are contained in 13 regional hydrogeologic units (four glacial and interglacial and nine alluvial). These units are briefly described in the following sections.

\section{GLACIAL-INTERGLACLAL SEQUENCE}

Both locally and regionally, the aquifer system within the glacial and interglacial deposits may be considered a sequence of aquifers and semiconfining to confining units. The areal extent of the aquifers in the sequence of deposits is determined by erosional and depositional processes resulting from the advances and retreats of the glaciers and the formation of and deposition in the alluvial valleys. Topography, the configuration of the basement confining unit, and the presence of saltwater bodies further act to divide and truncate the flow systems in the aquifers.

Recessional deposits present at land surface can be categorized into four groups-(1) locally nonextensive, discontinuous deposits that, depending on the physical setting, may or may not be saturated; (2) horizontally and vertically extensive deposits that in some areas are in direct contact with advance outwash; (3) thick recessional channel-fill deposits that in some areas also are in direct contact with the underlying advance outwash; and (4) glaciomarine deposits. The first and last groups generally do not function as aquifers, though the first group can locally provide water for domestic use. The second and third groups function as aquifers. Each of these groups has been included in a regional unit described in the following sections.

\section{Surficial Semiconfining Unit}

The fine-grained (generally till) deposits present at land surface generally have much larger hydraulic conductivity than the fine-grained (generally lacustrine) interglacial sediments; however, their conductivity generally is one to three orders of magnitude smaller than the coarse-grained deposits. Available data indicate that the till can act as either a semiconfining unit or a low-yield aquifer unit. Although these deposits do not appear to largely affect flow systems, they limit groundwater recharge and affect ground-water availability, contaminant transport, and surface-water runoff. Therefore, these deposits have been separated out from the other glacial and interglacial deposits as a distinct (semiconfining) unit. Where the Everson "glaciomarine" Drift is at land surface, excluding the Fraser-Whatcom Basin, it is considered to be part of this regional semiconfining unit. The locally nonextensive recessional outwash deposits also are considered part of this unit. Last, extensive mudflow deposits along the White River in Pierce and King Counties are considered part of the surficial semiconfining unit. Thus, excluding the Fraser-Whatcom Basin, the surficial semiconfining unit includes most of the surficial fine-grained deposits shown in figure 6 .

\section{Confining Unit}

On a regional basis, only the shallowest, finegrained, clayey deposits that are areally extensive appear to largely affect the ground-water flow system; these deposits generally are located near sea level 


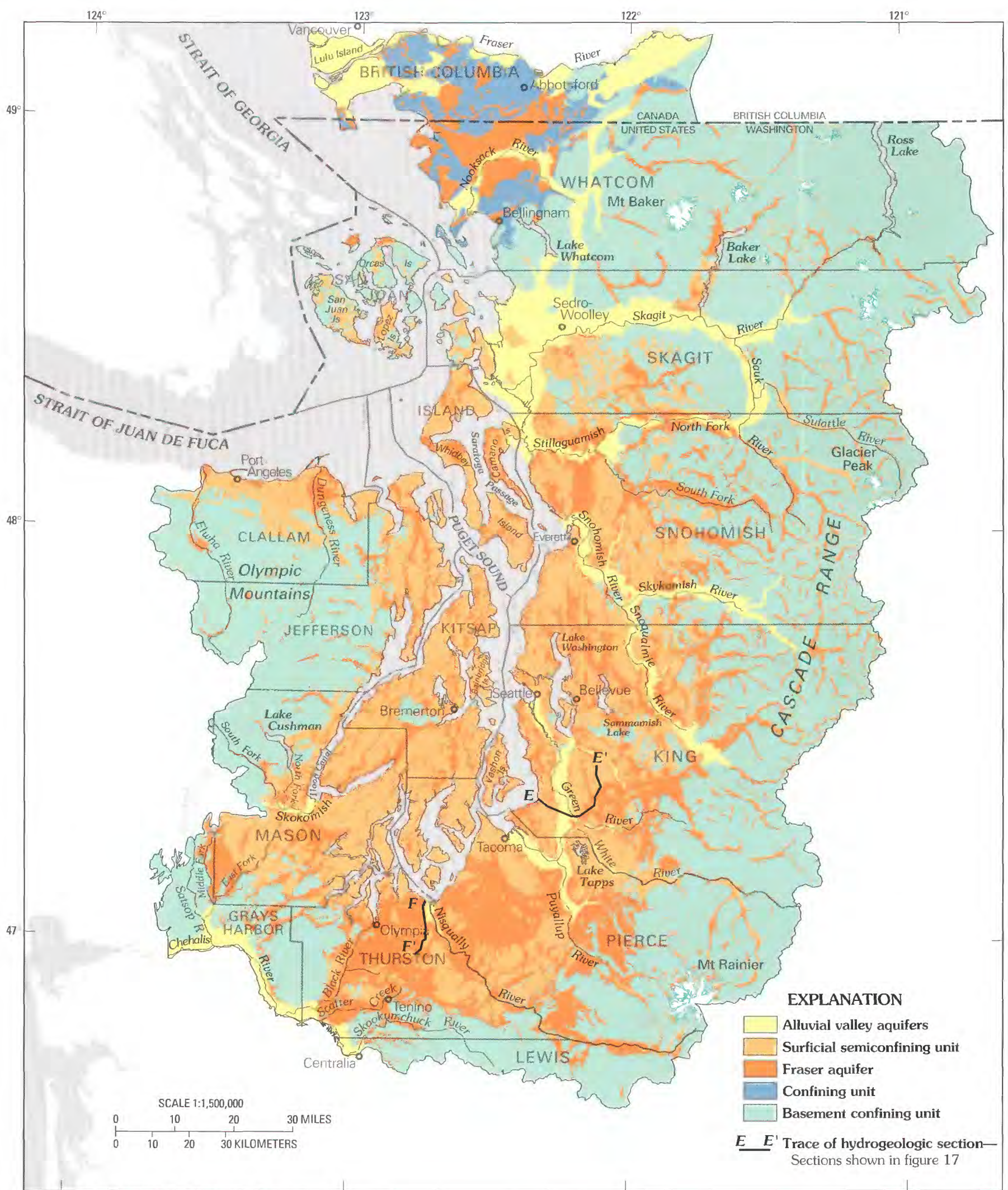

Base modified from U.S. Geological Survey digital data, 1:2,000,000, 1972

FIGURE 15. - The lateral extents of the surficial regional hydrogeologic units. Names of alluvial valley aquifers identified by names of rivers. 


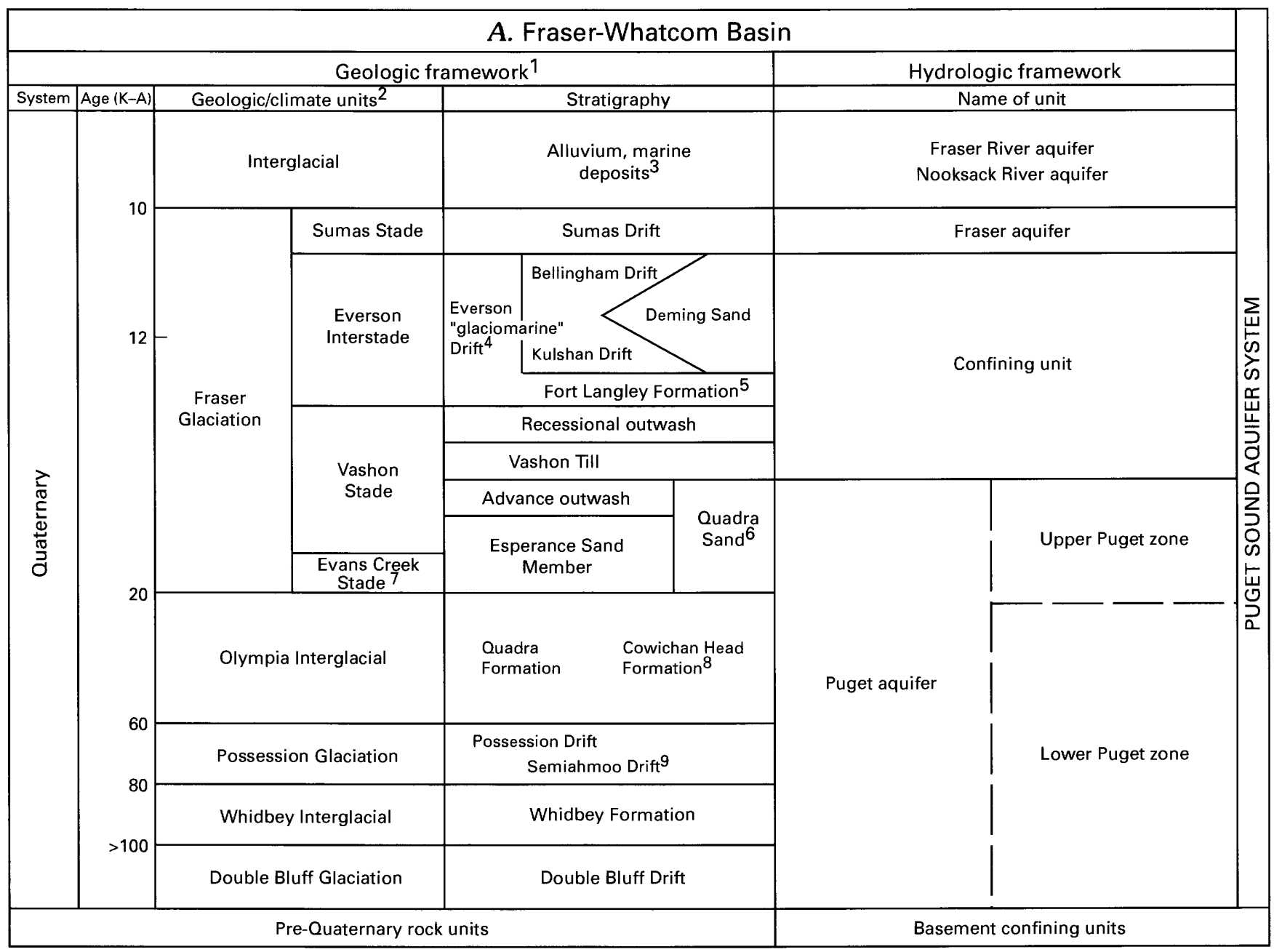

1 Modified from D. Molenaar (U.S. Geological Survey, written commun., 1982), P.C. Haase (U.S. Geological Survey, written commun., 1988), Blunt and others (1987), and Galster and Coombs (1989).

2 Drift sequences are generally separated by unconformities.

3 Marine deposits are considered part of aquifer system where saturated with freshwater.

4 Also includes glaciaofluvial sediments-Everson sand (early Everson) and Everson gravel (late Everson).

5 Canadian name for Everson glaciomarine drift.

6 Canadian name for Vashon deposits older than till, although in many locations the unit does not include the advance outwash.

7 Deposits of similar age and older than Evans Creek Strade generally not exposed in the basin, inferred from well-log information and from some exposures in Canada.

8 Canadian name for Olympia Interglacial deposits

9 Canadian name for pre-Olympia Interglacial deposits.

FIGURE 16.- Relation between stratigraphic units and regional hydrogeologic units for the Puget Sound aquifer system, (A) FraserWhatcom Basin, (B) north-central Puget Sound Lowland, and (C) southern Puget Sound Lowland. Location of areas shown in figure 6. 


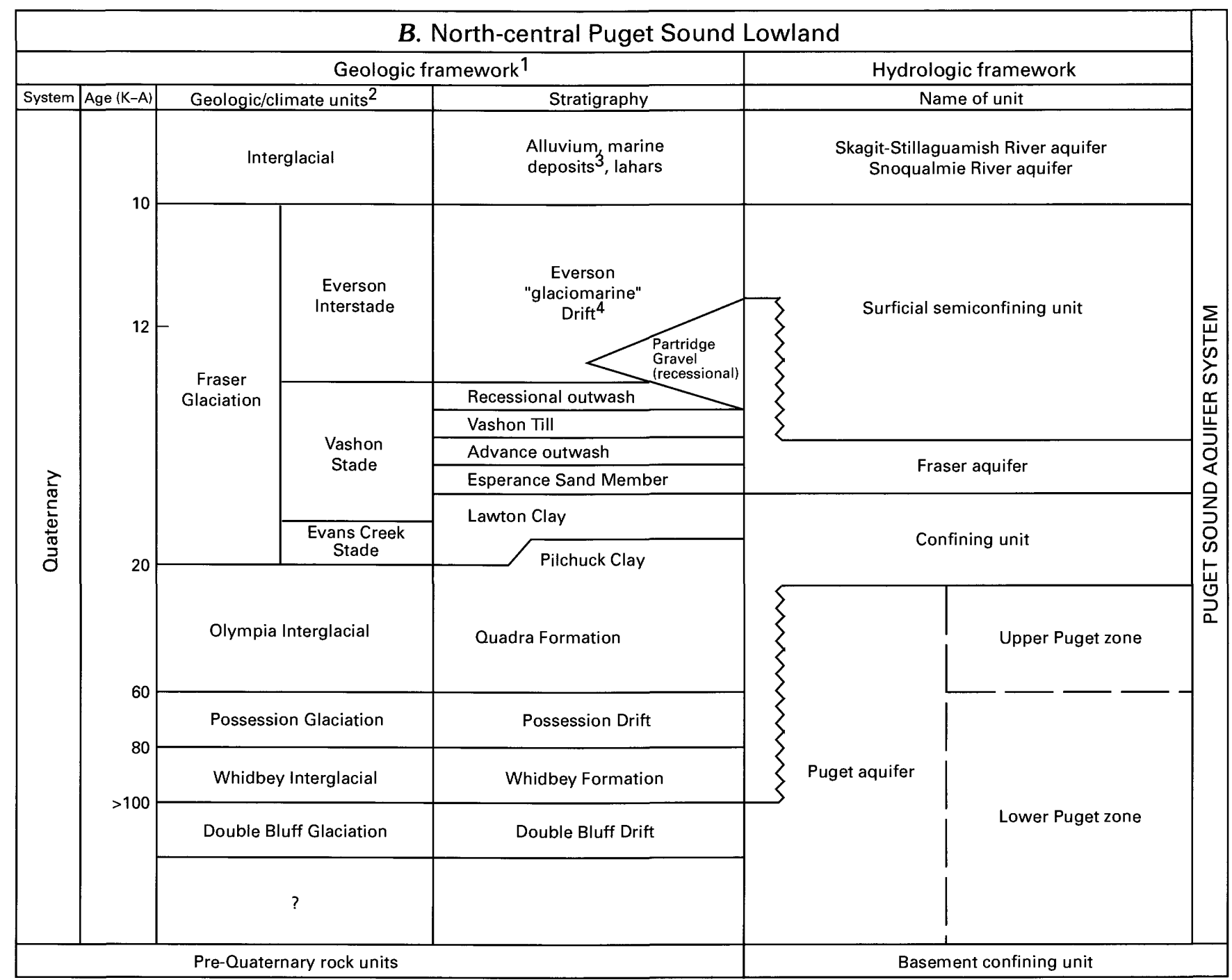

1 Modified from D. Molenaar (U.S. Geological Survey, written cummun., 1982), P.C. Haase (U.S. Geological Survey, written commun., 1988), Blunt and others (1987), and Galster and Coombs (1989).

2 Drift sequences are generally separated by unconformaties.

3 Marine deposits are considered part of aquifer system where saturated with freshwater.

4 Also includes glaciaofluvial sediments-Everson sand (early Everson) and Everson gravel (late Everson).

FIGURE 16.- Relation between stratigraphic units and regional italic hydrogeologic units for the Puget Sound aquifer system, ( $A$ ) FraserWhatcom Basin, $(B)$ north-central Puget Sound Lowland, and $(C)$ southern Puget Sound Lowland. Location of areas shown in figure 6-Continued.

where they abut saltwater bodies. These fine-grained deposits are considered a regional confining unit and are called the confining unit. In the Fraser-Whatcom Basin, the Everson "glaciomarine" Drift is considered the confining unit. Although the till at the land surface is part of the surficial semiconfining unit where it directly overlies the coarse-grained outwash or proglacial deposits, it may be considered part of the confining unit where it is in direct contact with the finegrained, clayey deposits. For example, the Vashon till crops out in the Fraser-Whatcom Basin where it has not been either eroded or covered by Everson "glaciomarine" Drift. Where it crops out in the low-lying parts of this basin, it abuts the Everson Drift, and where it is 


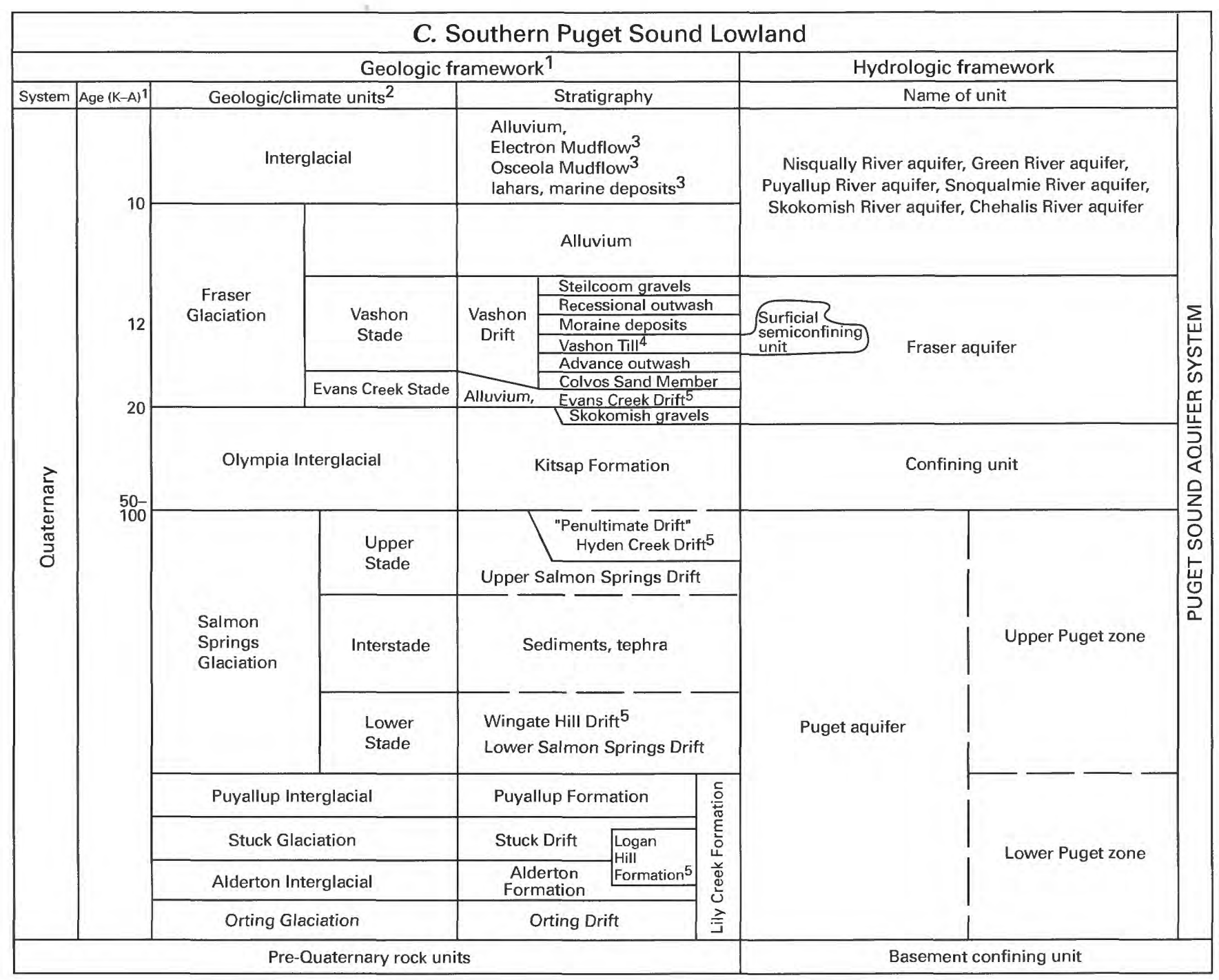

1 Modified from D. Molenaar (U.S. Geological Survey, written commun., 1982), P.C. Haase (U.S. Geological Survey, written commun., 1988), Blunt and others (1987), and Galster and Coombs (1989).

2 Drift sequences are generally separated by unconformities.

3 Mudflows and lahars are part of alluvial valley aquifers where confined in channels and not principal unit in channel, otherwise, considered part of surficial semiconfining unit; marine deposits are considered part of aquifer system where saturated with freshwater.

4 Vashon Till makes up the surficial semiconfining unit where it crops out at land surface or is covered by only a thin veneer of younger unsaturated deposits.

5 Alpine glacial deposits, generally located in mountainous areas of Cascade Range.

FIGURE 16.-Relation between stratigraphic units and regional italic hydrogeologic units for the Puget Sound aquifer system, (A) FraserWhatcom Basin, $(B)$ north-central Puget Sound Lowland, and $(C)$ southern Puget Sound Lowland. Location of areas shown in figure 6-Continued.

buried, it underlies the Everson Drift (and perhaps some Vashon recessional outwash). Thus, for this regional analysis, the Vashon till is considered part of the confining unit in this basin. Although in other areas the Vashon till is known to be locally in contact with the fine-grained confining unit, it was not considered part of the confining unit because of the regional scale of this study. For local investigations, it probably would be 

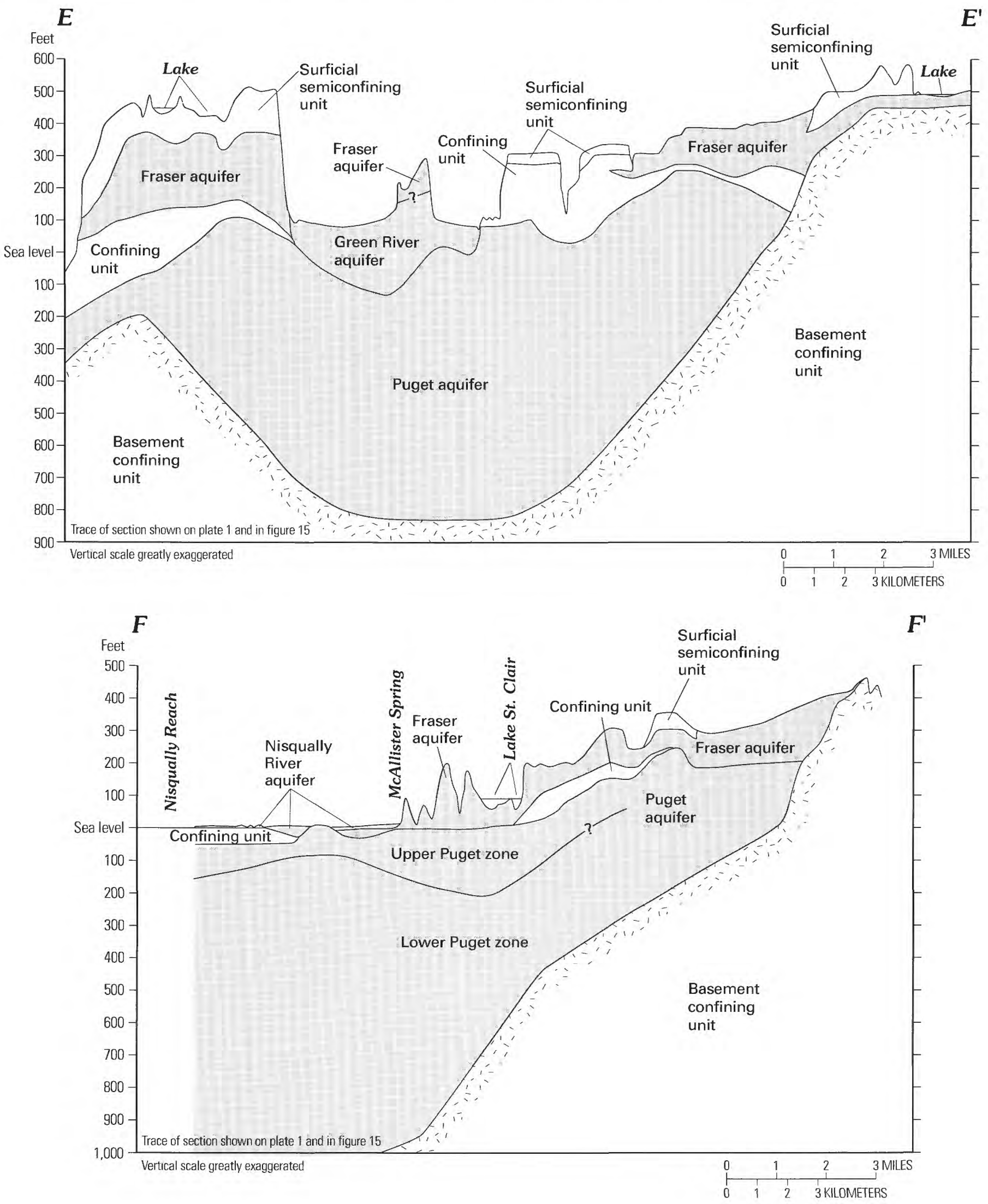

FIGURE 17.-Examples of extent and names of regional hydrogeologic units for (A) section $E-E^{\prime}$ and $(B)$ section $F-F^{\prime}$. 
combined with the confining unit. Additionally, the older, buried till that is in contact with the overlying confining unit has not been included as part of the confining unit. However, as described previously in "Hydrogeologic Units and Sections," this unit may or may not be combined with the confining unit in local investigations.

\section{Fraser and Puget Aquifers}

For this regional study, the aquifer units consist of all deposits not included in either the surficial semiconfining unit or the confining unit. The aquifer units thus consist of glacial outwash, proglacial, interglacial, and locally, alluvial and mudflow deposits. Where present, the aquifer unit that overlies the confining unit is called the Fraser aquifer, and the aquifer unit that underlies the confining unit is called the Puget aquifer. Locally, the Puget aquifer may be further informally divided into the upper Puget zone and the lower Puget zone. The glacial and interglacial deposits thus comprise two aquifer units, one semiconfining unit, and one confining unit. Water in the Fraser aquifer occurs under watertable to semiconfined conditions, and water in the Puget aquifer generally occurs under confined conditions. Generally, the Fraser aquifer corresponds to the regional water-table aquifer.

\section{ALLUVIAL VALLEY AQUIFERS}

The alluvial valley aquifers are comprised of extensive alluvial deposits in the major river valleys. These valleys traverse the glacial deposits in the study area, and the rivers in the valleys discharge to saltwater bodies; some of these valleys originate in the bedrock uplands. These alluvial valley aquifers truncate and control the flow systems in the glacial and interglacial deposits, and they typically are linear-type features; that is, their length is much greater than their width. Each of these alluvial aquifers closely follows the associated river valley and is considered a separate aquifer unit for this regional study.

In the selected parts of the upper reaches of the rivers in the bedrock-controlled valleys, glacial (recessional, till, and advance), interglacial, and mudflow deposits are considered part of the alluvial valley aquifer units; this is due to the generally small extent of these deposits in comparison to the alluvial deposits and, in many instances, the similarity of hydraulic characteristics of the alluvial deposits and of the continental and alpine glacial deposits. Where the mudflow deposits are extensive, such as along the White River, they have not been included in the alluvial aquifers. Less extensive and also discontinuous alluvial deposits are not separated as alluvial valley aquifers. Generally, these deposits have been included in the surficial semiconfining unit where they overlie till or other finegrained deposits or in the Fraser aquifer where they overlie coarse-grained deposits. On the basis of the extent of the alluvium in the major river valleys, nine alluvial valley aquifers have been identified and named (figs. 15 and 16). Note that in some areas-the Nooksack, Nisqually, and Skokomish Rivers-the alluvial deposits are laterally extensive but do not appear to be vertically extensive.

\section{RECESSIONAL DEPOSITS}

Well-defined, deep recessional outwash channels filled with coarse-grained glacial deposits are productive aquifers. However, except for one major channel, the South Tacoma channel in Pierce County, the channels generally are valleys that are now occupied by streams and are located both in the bedrock-controlled upper reaches of rivers and in most of the valleys in the southern part of the study area. Therefore, they are not defined as separate aquifer units, but depending on their locations, they are considered part of either the alluvial valley aquifers or the Fraser aquifer. For this study, the South Tacoma channel also is not defined as a separate aquifer unit but is considered a highly productive part of the Fraser aquifer. Additionally, nonchannelized extensive recessional outwash deposits are considered part of the Fraser aquifer. These deposits are most prevalent in the southern part of the study area. For this area, the underlying till (if present) also is considered part of the Fraser aquifer.

\section{APPLICATION OF CONCEPTUAL MODEL}

The conceptual model was applied to a selected area in the Fraser-Whatcom Basin by using available welllog information and maps showing the extents of surficial hydrogeologic units (S.E. Cox, U.S. Geological Survey, written commun., 1993; Jones, in press; fig. 15) to map the regional hydrogeologic units presented in figure 16 for the Fraser-Whatcom Basin. The units were mapped within a section that follows an approximate ground-water flow line estimated from the generalized water-level configurations (fig. 10). A cross-sectional ground-water flow model then was constructed for the section. The model was constructed on regionally representative values that accorded with the conceptual model. For example, the hydraulic characteristics of the units were estimated from effective average or median values, on the basis of information described previously both in the "Hydraulic Characteristics" section and in the development of the conceptual model, and because the upper part of the aquifer system in the basin 
appears to be more coarse grained than other areas within the Puget Sound Lowland, the effective values used in the model were larger for this part of the system. The results of the model then were compared with the estimated generalized water-level configurations shown in figure 10, with measured water levels in wells, and with estimated water-level configurations obtained from maps constructed during a multiyear study of the ground-water flow system in part of Whatcom County and British Columbia, Canada (S.E. Cox, U.S. Geological Survey, written commun., 1993). Model-calculated water budgets also were compared to streamflow in the Nooksack River.

The Fraser aquifer exists in the basin and has been called the Abbotsford aquifer in part of British Columbia (Liebscher and others, 1992) and the Sumas-Abbotsford aquifer in part of both Whatcom County and British Columbia (S.E. Cox, U.S. Geological Survey, written commun., 1993). The Fraser aquifer provides a large part of the water used for municipal, domestic, and agricultural uses. Most of the wells within the basin are highly productive and shallow. Additionally, water also is obtained from the Nooksack River aquifer. Throughout much of the Fraser-Whatcom Basin, ground-water levels are near land surface. In many areas, ditches and agricultural drains intercept the water table and discharge water from the aquifer system to local streams and the Nooksack River, which traverses part of the basin (fig. 2).

A large part of the deposits in the Fraser-Whatcom Basin exhibit larger than average hydraulic conductivities for the aquifer system. The larger values are due to the fact that surficially (excluding the Everson "glaciomarine" Drift), and to some extent with depth, the uppermost deposits consist principally of coarsegrained outwash and alluvial deposits (Jones, in press). Additionally, much of the surficial deposits were not overridden by the last incursion of continental glaciers during the Sumas Stade.

The constructed section $G-G^{\prime}$ (fig. 18) extends over $9.59 \mathrm{mi}$, from about $4 \mathrm{mi}$ south of the Fraser River in British Columbia to the Nooksack River in Whatcom County. The Nooksack River aquifer (fig. 16) is comprised of Holocene alluvial deposits and is present at the southern or downgradient end of the section (fig. 18). The Nooksack River aquifer was combined with the Fraser aquifer for modeling purposes because the Nooksack River aquifer in this location of small topographic relief is relatively thin and grades laterally into the Fraser aquifer. The Fraser aquifer in this area is comprised of the Sumas Drift, and the confining unit is comprised of the divided units (Bellingham Drift and Kulshan Drift) that compose the Everson "glaciomarine" Drift, recessional outwash, and the Vashon till (figs. 16 and 18). The Puget aquifer is comprised of the remaining stratigraphic units that compose the undifferentiated glacial and interglacial deposits underlying the confining unit (figs. 16 and 18). The basement confining unit within the basin consists of consolidated continental sediments, principally sandstone, probably the most permeable of the units that compose the basement confining unit. Therefore, to test potential flow to and from the basement confining unit, the upper $250 \mathrm{ft}$ of the sandstone was included as a model layer.

The cross-sectional numerical model of groundwater flow was constructed using 25 square cells in the horizontal dimension; the cells have lengths and widths of $2,025 \mathrm{ft}$ (fig. 18). Excluding the sandstone, vertical discretization was based on the average thickness over a cell for each of the mapped units (fig. 18). The boundary condition for each of the uppermost cells was a constant rate of recharge (average of $26.7 \mathrm{in} / \mathrm{yr}$ ) that was obtained from the distribution shown in figure 13. The boundary condition for the contact between the upper part of the basement confining unit and the remainder of the basement confining unit was defined as no flow. Although the upgradient (north) end of the section was placed at an estimated ground-water divide on the basis of shallow water-level data, the lateral boundary condition for the vertical column of cells was identified as a head-dependent boundary and was simulated using the GHB module of the ground-water flow model. Similarly, the lateral boundary condition for the southern end of the section, which extends beyond the Nooksack River, also was identified as a head-dependent boundary and was simulated using the GHB module; the section was extended three cells beyond the river to account for the contribution of flow to the river originating from the other side. The river module was used to simulate flow to the Nooksack River. The ET module was used to simulate ET from the uppermost cells where the water levels are near land surface (see fig. 18) such that plants may extract ground water on the basis of unused PET (PET - AET). The drain module was used for 12 cells where water can discharge from the Fraser aquifer; these cells represent agricultural drains, ditches, seeps, springs, and streams. Note that discharge from the aquifer system to these drain cells goes to the Nooksack River, and thus, the total contribution of ground water to the river along the section is the discharge to both the river and drain cells. The model grid system with boundary conditions is shown in figure 18 .

Horizontal hydraulic conductivities were estimated as previously described, and these values correspond to basinwide estimates provided by S.E. Cox (U.S. Geological Survey, written commun., 1993). Except for the Fraser aquifer, conductivities in each layer were nearly uniform. Conductivity of the sandstone (the basement 


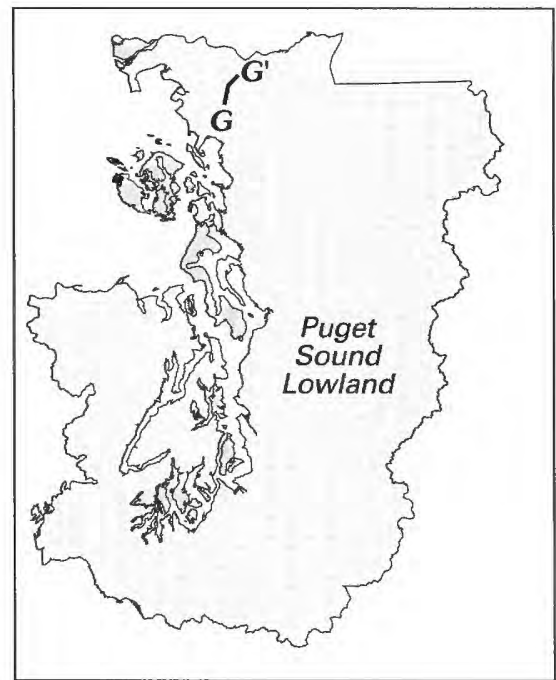

Inset map

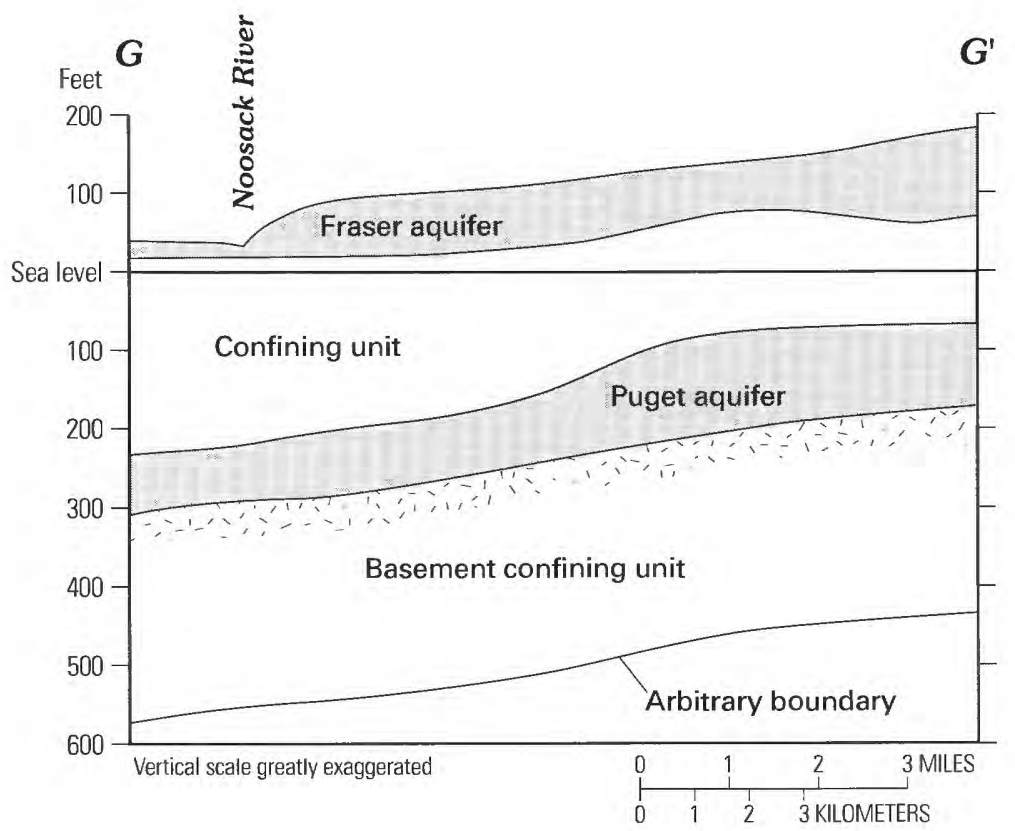

G

$G^{\prime}$

\section{EXPLANATION}

Model cell-Number identifies layer

Drain boundary cell

River boundary cell

General head boundary

Evapotraspiration boundary cell

Aquifer

Bedrock-Basement confining unit

Sea level

$G-G^{\prime}$ Trace of section-Shown on inset map

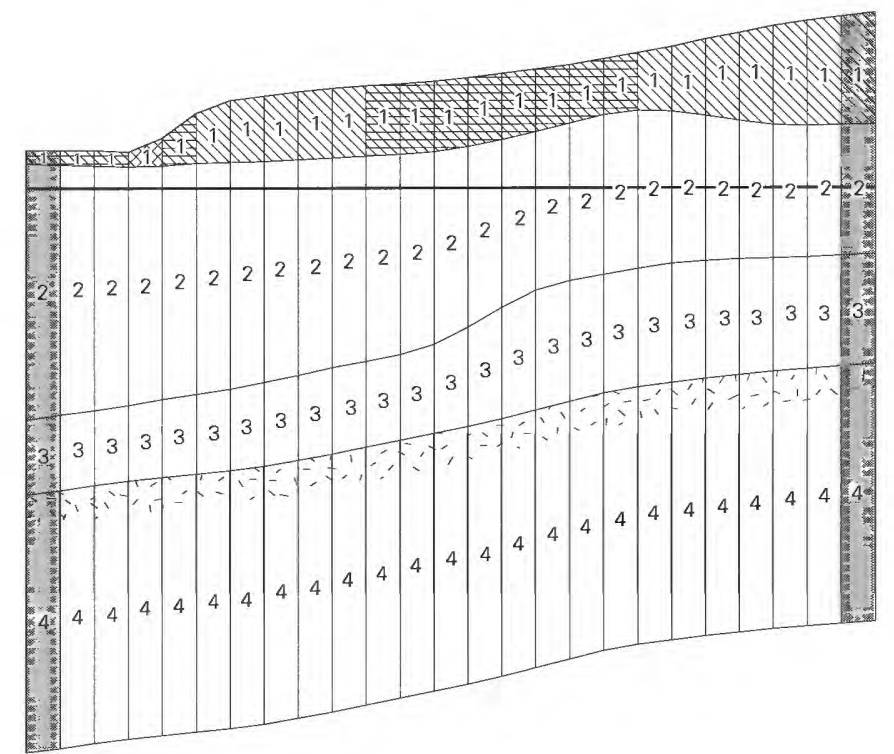

FIGURE 18.-Geometry of aquifer and confining units and model grid system with boundary conditions for section $G-G^{\prime}$, FraserWhatcom Basin.

confining unit) was estimated to be about $17-\mathrm{ft} / \mathrm{d}$; Cox (U.S. Geological Survey, written commun., 1993) estimated the sandstone conductivities to range from about 0.01 to $75 \mathrm{ft} / \mathrm{d}$. The $17-\mathrm{ft} / \mathrm{d}$ value is similar to Cox's 75th-percentile value (the larger estimate was chosen to test for maximum potential flow in the basement confining unit). Vertical conductance was estimated as pre- viously described for the other constructed groundwater flow models.

A comparison of the calculated hydraulic heads for the Fraser aquifer to the estimated water levels shown in figure 10 and to water levels measured and mapped by S.E. Cox (U.S. Geological Survey, written commun., 1993) shows that the calculated heads are in reasonable agreement with the previously mapped heads (fig. 19). 
Map view

G

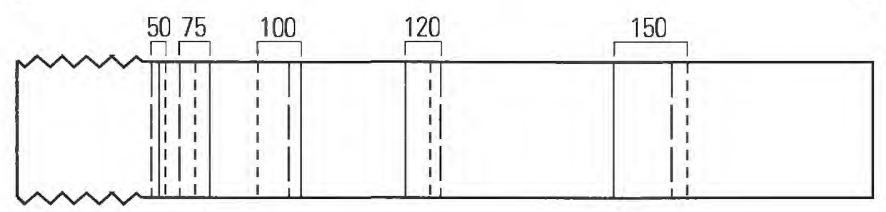

\section{EXPLANATION}

$G^{\prime}$

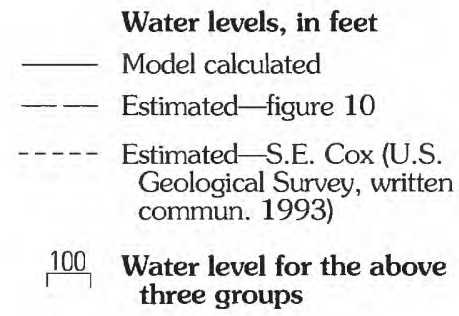

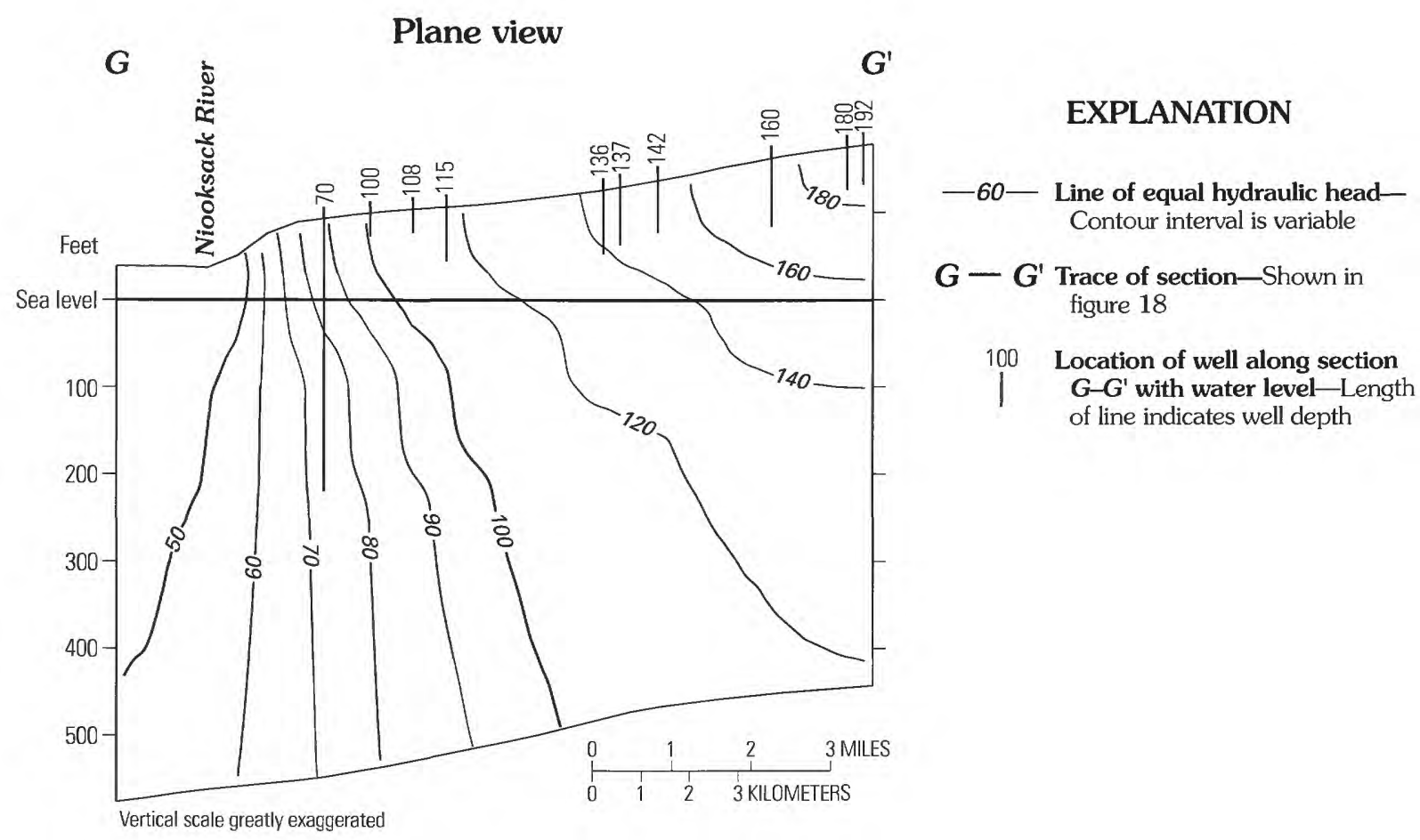

FIGURE 19.-Model-calculated hydraulic heads and estimated and observed water levels for section $G-G^{\prime}$, Fraser-Whatcom Basin.

For 22 cells representing the Fraser aquifer, the mean absolute difference between the model calculated heads and Cox's mapped heads is $12.5 \mathrm{ft}$ or about 8 percent of the total hydraulic-head change along this $8.44 \mathrm{mi}$ part of the section.

Calculated lateral gradients range from 0.0004 to $0.01 \mathrm{ft} / \mathrm{ft}$ for the Fraser aquifer and from 0.0002 to $0.004 \mathrm{ft} / \mathrm{ft}$ for the Puget aquifer; average lateral gradients are 0.003 and $0.002 \mathrm{ft} / \mathrm{ft}$ for the Fraser and Puget aquifer, respectively. The model calculated a $60-\mathrm{ft}$ smaller total lateral head change in the Puget aquifer than in the Fraser aquifer. The maximum lateral gradients occur at a terrace abutting the Nooksack River. The average calculated lateral gradients are smaller than the regional estimates described previously; the smaller values correspond to the large hydraulic conductivities (on the order of 100 to $200 \mathrm{ft} / \mathrm{d}$ ) estimated for the deposits of the Fraser aquifer along the section. Calculated downward vertical gradients from the Fraser aquifer to the Puget aquifer ranged from about 0.02 to $0.16 \mathrm{ft} / \mathrm{ft}$. The values were largest at the upgradient end of the section and smallest at the transition from downward-to-upward vertical gradients (this transition occurred where the terrace abuts the river). Upward gradients, ranging from about 0.01 to $0.06 \mathrm{ft} / \mathrm{ft}$, occurred at the five most-downgradient cells below the alluvial valley. The range and direction of the vertical gradients are similar to those discussed previously in the report. 
Model results indicate that of the average annual recharge $\left(7.23 \mathrm{ft}^{3} / \mathrm{s}\right)$ to layer 1,80 percent $\left(5.82 \mathrm{ft}^{3} / \mathrm{s}\right)$ discharges to the Nooksack River either directly or indirectly through drains, and 20 percent $\left(1.41 \mathrm{ft}^{3} / \mathrm{s}\right)$ discharges through evapotranspiration. An additional $0.22 \mathrm{ft}^{3} / \mathrm{s}$ enters the system through the lateral boundaries (for a total recharge of $7.45 \mathrm{ft}^{3} / \mathrm{s}$ ) and discharges to drains and the river. No water exited the system from the lateral boundaries. Total discharge to the river is thus $6.04 \mathrm{ft}^{3} / \mathrm{s}\left(2.49 \mathrm{ft}^{3} / \mathrm{s}\right.$ directly to the river and $3.55 \mathrm{ft}^{3} / \mathrm{s}$ through drains).

Model results indicate that about 44 percent of the recharge $\left(3.18 \mathrm{ft}^{3} / \mathrm{s}\right)$ to layer 1 (Fraser aquifer) moves into layer 2 (the confining unit), and eventually back to layer 1 ultimately to discharge. The remaining 56 percent of the recharge $\left(4.05 \mathrm{ft}^{3} / \mathrm{s}\right)$ discharges to drains and as evapotranspiration. Of the water that moves into layer 2 , only about 13 percent $\left(0.41 \mathrm{ft}^{3} / \mathrm{s}\right)$ moves into layer 3 (the Puget aquifer), indicating that the upper part of the flow system is the most active part and that recharge is discharged predominantly in local flow systems (even on this spatial scale). Less than onehalf of 1 percent $\left(0.025 \mathrm{ft}^{3} / \mathrm{s}\right)$ of the total recharge was calculated to occur as lateral inflow into layer 4 (the basement confining unit) from the GHB cells. Additionally, only about $0.28 \mathrm{ft}^{3} / \mathrm{s}$ (4 percent of the recharge to layer 1) was calculated as moving from layer 3 into layer 4 and back to layer 3 . Therefore, even when large conductivities are used in the model for layer 4 (the basement confining unit), the flow contribution from and the quantity of water moving in the upper part of the basement confining unit are estimated to be minimal.

On the basis of U.S. Geological Survey's gaged discharge of the Nooksack River, the Nooksack River gains water from the point where it enters the lowlands until it discharges to saltwater at an annual average rate that ranges from about 2 to $10\left(\mathrm{ft}^{3} / \mathrm{s}\right) / \mathrm{mi}^{2}$ and averages about $3\left(\mathrm{ft}^{3} / \mathrm{s}\right) / \mathrm{mi}^{2}$. The latter value can be compared to the average annual unit recharge rate of $1.96\left(\mathrm{ft}^{3} / \mathrm{s}\right) / \mathrm{mi}^{2}$ or, after accounting for evapotranspiration, $1.64\left(\mathrm{ft}^{3} / \mathrm{s}\right) / \mathrm{mi}^{2}$. Although these values are smaller than the average unit streamflow gain (indicating that estimates of recharge may be too small), a part of the gain also may be derived from direct surface runoff and, thus, would not be included in the recharge estimates.

The calculated discharge to the river from the section is $6.04 \mathrm{ft}^{3} / \mathrm{s}$, which corresponds to $15.7\left(\mathrm{ft}^{3} / \mathrm{s}\right) / \mathrm{mi}$ of river. Streamflow data indicate that discharge to the river ranges from about 6 to $27\left(\mathrm{ft}^{3} / \mathrm{s}\right) / \mathrm{mi}$ of river and averages about $9\left(\mathrm{ft}^{3} / \mathrm{s}\right) / \mathrm{mi}$ of river. The calculated contribution per mile of river is much larger than the observed average contribution. However, this difference probably is due to the fact that the modeled area-to-river mile ratio $\left(3.68 \mathrm{mi}^{2} / 0.38 \mathrm{mi}\right.$ or $\left.9.6 \mathrm{mi}\right)$ for the section is three times larger than the area-to-rivermile ratio $(3.2 \mathrm{mi})$ based on the location of the gaging stations. This aspect highlights the potential for increased flow from a basin with long flowpaths with a large contributing area such that larger quantities of recharge are intercepted. Additionally, the large range in observed discharge per mile of river further shows the effects of interannual variability in precipitation and, thus, in recharge in this basin. An example of this variability is that water-year precipitation near Bellingham (located in the western part of the Fraser-Whatcom Basin, fig. 2) has ranged from about 22 to $48 \mathrm{in} / \mathrm{yr}$.

\section{SUMMARY AND GONGLUSIONS}

The aquifer systems in the Puget-Willamette Lowland were studied by the U.S. Geological Survey as part of a national Regional Aquifer-System Analysis Program. The Puget-Willamette Lowland is located in western Washington, western Oregon, and a small part of southwestern British Columbia, Canada, and consists of two distinct areas-the Puget Sound Lowland and the Willamette Lowland. The study area for this report is the Puget Sound Lowland, which encompasses $17,616 \mathrm{mi}^{2}$, about $2,556 \mathrm{mi}^{2}$ of which is saltwater.

The Puget Sound Lowland is an elongated basin that extends over about $200 \mathrm{mi}$ in a north-south direction; the width of the lowlands ranges from 15 to $80 \mathrm{mi}$ and averages about $40 \mathrm{mi}$. The Puget Sound Lowland is a discontinuous valley that is part of a larger forearc basin, the topography and geology of which are products of tectonic convergence of oceanic and continental plates. Pleistocene glaciation has modified the regional geologic setting of the Puget Sound Lowland. There have been at least four recognized continental glaciations and several alpine glacial advances. As a result of the glaciations, the Quaternary deposits locally consist of one to several regional drift sequences that generally are separated by unconformities and by nonglacial fluvial and lacustrine sediments. The drift sequences are overlain by large thicknesses of alluvial sediments in the major broad alluvial valleys in the area.

Excluding large lakes, the Puget Sound aquifer system underlies 7,183 $\mathrm{mi}^{2}$ of the Puget Sound Lowland. Alluvial, glacial, and interglacial sediments of Quaternary age compose the Puget Sound aquifer system; these deposits consist principally of recent alluvial, recessional and advance outwash, till, and other glaciofluvial and interglacial sediments. Tertiary and older sedimentary, volcaniclastic, volcanic, and metamorphic rock units underlie these sediments and form the lateral 
and basal boundaries of the aquifer system; together, these rock units are called the basement confining unit. The basement confining units crops out over about $7,760 \mathrm{mi}^{2}$ of the Puget Sound Lowland.

The areal extent of the Puget Sound aquifer system is generally delineated by the extent of the drift of the youngest glaciation, the Fraser Glaciation, and in particular, the Vashon Stade. The Vashon Drift is relatively undisturbed and close to the land surface in much of the Puget Sound Lowland. Of the $7,183 \mathrm{mi}^{2}$ of unconsolidated deposits present at the land surface in the Puget Sound Lowland, alluvial deposits overlie $1,570 \mathrm{mi}^{2}$; fine-grained deposits (mainly glacial till but including other deposits such as glaciomarine drift and mudflows) overlie $3,320 \mathrm{mi}^{2}$; and coarse-grained deposits (mainly recessional and advance outwash) overlie $2,293 \mathrm{mi}^{2}$.

The Quaternary deposits were divided into regional hydrologic units-aquifers, semiconfining units, and confining units. The aquifer units generally consist of coarse-grained outwash deposited during glacial advances and retreats, proglacial deposits, and fluvial sediments deposited during glacial interstades. The semiconfining and confining units generally consist of fine-grained till, glaciomarine, mudflow, and lake deposits. This alternating sequence of coarse- and finegrained deposits occurs from land surface to depths of more than $3,300 \mathrm{ft}$ and averages about $400 \mathrm{ft}$ thick. Individual units range in thickness from 10 to more than $400 \mathrm{ft}$.

On the basis of the information presented in the report, it was estimated that there is no significant regional flow system in the Puget Sound aquifer system under the present conditions of hydrologic stress. The Puget Sound aquifer system contains subregional flow systems that are generally isolated from each other.

Ground-water movement generally is from topographic highs to topographic lows, the latter of which typically are stream drainages or saltwater bodies. The direction of ground-water movement is predominantly horizontal in the aquifer units and vertical in the semiconfining and confining units. Vertical gradients generally are downward, except near streams and saltwater bodies where gradients are upward. Ground water in the uppermost aquifer unit generally occurs under water-table conditions, and ground water in the deeper units is confined.

Horizontal hydraulic-head gradients generally range from 10 to $70 \mathrm{ft} / \mathrm{mi}(0.002$ to $0.013 \mathrm{ft} / \mathrm{ft})$ and average about $30 \mathrm{ft} / \mathrm{mi}(0.006 \mathrm{ft} / \mathrm{ft})$. The gradients are flattest in coarse recessional outwash and alluvial deposits and are steepest in fine-grained deposits and in all deposits located just upgradient of cliffs and cuts. Vertical hydraulic-head gradients generally range from about 0.004 to $1.6 \mathrm{ft} / \mathrm{ft}$ and appear to average about $0.3 \mathrm{ft} / \mathrm{ft}$. Vertical head differences range from about 1 to $200 \mathrm{ft}$ over at least the upper $600 \mathrm{ft}$ of the aquifer system.

Horizontal hydraulic conductivity for the aquifer units generally ranges from about 10 to $700 \mathrm{ft} / \mathrm{d}$, and median values generally are in the range of 15 to $50 \mathrm{ft} / \mathrm{d}$. Values larger than $50 \mathrm{ft} / \mathrm{d}$ generally are associated with coarse-grained outwash or alluvial deposits. Values less than about $10 \mathrm{ft} / \mathrm{d}$ indicate fine-grained deposits. Regional effective vertical hydraulic conductivity of the till is estimated to range between 0.001 and $0.01 \mathrm{ft} / \mathrm{d}$, and vertical hydraulic conductivity of fine-grained (clayey) interglacial deposits is on the order of $0.0001 \mathrm{ft} / \mathrm{d}$. Vertical hydraulic conductivity of fine-grained glaciomarine drift probably ranges from 0.001 to $0.1 \mathrm{ft} / \mathrm{d}$.

Mean annual recharge from precipitation was estimated to be about $27 \mathrm{in} / \mathrm{yr}$ or $14,510 \mathrm{ft}^{3} / \mathrm{s}$. This quantity is 51 percent of the 53 in. of average annual precipitation that falls on the aquifer system. Recharge was estimated from the results of previous studies, and the estimates were derived using linear regression based on average annual precipitation, surficial geology, and land use and cover. Recharge was estimated to range spatially from about 0 to more than $70 \mathrm{in} / \mathrm{yr}$. The potential range in annual recharge is larger than the mean annual value. For example, if an area has an estimated mean annual recharge value of $20 \mathrm{in} / \mathrm{yr}$, then the range in annual recharge value can be on the order of 20 in.

The quality of water in the Puget Sound aquifer system is suitable for most purposes. The dominant water types are calcium bicarbonate, magnesium bicarbonate, calcium magnesium bicarbonate, and in some areas, sodium bicarbonate or sodium chloride. The water is generally soft to moderately hard. Dissolved solids generally are in the range of 100 to $150 \mathrm{mg} / \mathrm{L}$. Large concentrations of iron and manganese are common in the glacial aquifers of the Puget Sound aquifer system. Concentrations of dissolved nitrate generally are small, less than $1.0 \mathrm{mg} / \mathrm{L}$, expressed as nitrogen, except in some areas of the shallow parts of the aquifer system where land-use practices have resulted in large concentrations. Seawater has intruded some aquifers near the coast, as indicated by chloride concentrations of more than $100 \mathrm{mg} / \mathrm{L}$.

Cross-sectional numerical models of ground-water flow constructed for selected areas used both detailed and simplified (aggregated units) aquifer-system geometries. The aggregated geometry was based on the aggregation of multiple units into one unit for the part of the aquifer system that lies above the first major areally extensive, fine-grained (clayey) unit that is 
located near sea level where the unit is near saltwater. The results of the models showed the importance of topography, saltwater bodies, the configuration of the basement confining unit, and the presence of the first clay as varying hydrologic controls on the flow system and, thus, on ground-water movement. In addition, the geometry, recharge, and hydraulic characteristics of the aquifer system also control ground-water movement. Calculated hydraulic-head distributions and flow systems generally were similar under both detailed and simplified aquifer-system geometries. Increased horizontal flow was calculated using the simplified geometry, generally resulting in less discharge to saltwater bodies and decreased heads in the deeper system. Calculated differences in the water budgets between the two geometries generally are less than the potential error in field measurements of the water-budget components. On the basis of model results, it was estimated that between about 100 and $1,000 \mathrm{ft}^{3} / \mathrm{s}$ of the total ground-water recharge $\left(14,510 \mathrm{ft}^{3} / \mathrm{s}\right)$ discharges directly to saltwater bodies.

A simplified conceptual model of the Puget Sound aquifer system was described. This model includes the important regional characteristics of the aquifer system that are necessary to describe ground-water flow in the Puget Sound Lowland. The conceptual model of the aquifer system consists of four types of units-glacial and interglacial aquifers, semiconfining units, confining units, and alluvial valley aquifers. On the basis of regional characteristics of these units, the aquifer system was divided into nine alluvial valley aquifers, the surficial semiconfining unit, the Fraser aquifer, a confining unit, and the Puget aquifer. Additionally, in areas with large thicknesses of unconsolidated deposits, the Puget aquifer may be informally divided into the upper Puget zone and the lower Puget zone. The basement confining unit forms the lateral and basal boundaries of the aquifer system.

\section{SELEGTED REFERENGES}

Adams, J., 1984, Active deformation of the Pacific Northwest continental margin: Tectonics, v. 3, no. 4, p. 449-472.

Anderson, F.E., 1968, Seaward terminus of the Vashon continental glacier in the Strait of Juan de Fuca: Marine Geology, v. 6, p. 419-438.

Armstrong, J.E., Crandell, D.R., Easterbrook, D.J. and Noble, J.B., 1965, Late Pleistocene stratigraphy and chronology in southwestern British Columbia and northwestern Washington: Geological Society of America Bulletin, v. 79, p. 321-330.

Atwater, T., 1970, Implications of plate tectonics for the Cenozoic evolution of western North America: Geological Society of America Bulletin, v. 81, p. 3515-3536.
B.C. Environment, 1993, Groundwater resources of British Columbia: B.C. Environment, Water Management Division, Hydrology Branch, Ground water Section, 13 chapt., 3 append.

Bauer, H.H., and Vaccaro, J.J., 1987, Documentation of a deep percolation model for estimating ground-water recharge: U.S. Geological Survey Open-File Report 86-536, 180 p.

Berris, S.N., 1995, Conceptualization and simulation of runoff generation from three basins in Thurston County, Washington: U.S. Geological Survey Water-Resources Investigations Report 94-4038, 149 p.

Beven, K.S., Wood, E.F., and Sivapalan, M., 1988, On hydrological heterogeneity-catchment morphology and catchment response: Journal of Hydrology, v. 100, p. 353-375.

Blair, H.O., 1929, Underground water resources in the vicinity of Tacoma: Journal of American Water Works Association, v. 21, p. 1185-1195.

Blunt, D.J., Easterbrook, D.J., and Rutter, N.W., 1987, Chronology of Pleistocene sediments in the Puget Lowland, Washington, in Schuster, J.E., ed., Selected papers on the geology of Washington: Washington Division of Geology and Earth Resources Bulletin 77, p. 321-353.

Bodhaine, G.L., and Thomas, D.M., 1964, Magnitude and frequency of floods in the United States, Part 12, Pacific slope basins in Washington and upper Columbia River Basin: U.S. Geological Survey Water-Supply Paper 1687, $337 \mathrm{p}$.

Booth, D.B., 1984, Glacier dynamics and the development of glacial landforms in eastern Puget Lowland, Washington: Seattle, Washington, University of Washington, Doctor of Philosophy dissertation, 217 p., 1 pl, scale 1:100,000.

1987, Timing and processing of deglaciation along the southern margin of the Cordilleran ice sheet, in Ruddimun, W.F., and Wright, H.E., Jr., eds., North America and adjacent oceans during the last delegation: Boulder, Colorado, Geological Society of America, The Geology of North America, v. K-3, p. 71-90.

Bovee, K.D., 1982, A guide to stream habitat analyses using the Instream Flow Incremental Methodology: Washington D.C., U.S. Department of the Interior, Fish and Wildlife Service, Instream Flow Information Paper No. 12, FWS/OBS-82/26, 248 p.

Bretz, J. H., 1910, A preliminary paper on the glacial lakes of Puget Sound: Journal of Geology, v. 18, no. 5, p. 448-458.

-1911, Terminal moraine of the Puget Sound glacier: Journal of Geology, v. 19, no. 2, p. 161-174.

1913, Glaciation of the Puget Sound region: Washington Geological Survey Bulletin 8, 244 p., 24 pls.

Brown and Caldwell, 1985, Clover/Chambers Creek geohydrologic study: Seattle, Washington, Brown and Caldwell, unpaginated.

Byers, H.G., 1902, Potable and mineral water: Washington Geological Survey Annual Report 1901, v. 1, pt v., p. 1-11.

Cady, W.M., 1975, Tectonic setting of the Tertiary volcanic rocks of the Olympic Peninsula, Washington: U.S. Geological Survey Journal of Research, v. 3, p. 573-582.

Carr and Associates, 1983, Vashon/Maury Island water resources study: Tacoma, Washington, Carr and Associates, unpaginated. 1988, Report on the 1987-1988 test drilling program: Tacoma, Washington, unpaginated.

Cheney, E.S., 1987, Major Cenozoic faults in the northern Puget Lowland of Washington, in Schuster, J.E., ed., Selected papers on the geology of Washington: Washington Division of Geology and Earth Resources Bulletin 77, p. 149-168.

Cline, D.R., 1969, Availability of ground water in the Federal Way area, King County, Washington: U.S. Geological Survey OpenFile Report 69-44, 60 p. 
Crandell, D.R., Mullineaux, D.R., and Waldron, H.H., 1958, Pleistocene sequence in the southeastern part of the Puget Sound lowland, Washington: American Journal of Science, v. 256, p. 384-397.

Cummans, J.E., 1977, Low-flow characteristics of streams on the Kitsap Peninsula and selected adjacent islands, Washington: U.S. Geological Survey Open-File Report 76-704, 19 p.

Deeter, J.D., 1979, Quaternary geology and stratigraphy of Kitsap County, Washington: Bellingham, Western Washington University, unpublished M.S. thesis, $175 \mathrm{p}$.

Dethier, D.P., Safioles, S.A., and Pevear, D.R., 1981, Composition of till from the Clear Lake quadrangle, Skagit and Snohomish Counties, Washington: U.S. Geological Survey Open-File Report 81$517,55 \mathrm{p}$.

Dickinson, W.R., 1976, Sedimentary basins developed during evolution of Mesozoic-Cenozoic arc-trench systems in western North America: Canadian Journal of Earth Sciences, v. 13, p. 1268 1283.

Dietrich, W.E., 1975, Surface-water resources of San Juan County, in Russell, R.H., ed., Geology and water-resources of the San Juan Island, San Juan County, Washington: Washington Department of Ecology Water-Supply Bulletin 40, p. 21-39, 3 pls.

Dinicola, R.S., 1990, Characterization and simulation of rainfall-runoff relations for headwater basins in western King and Snohomish Counties, Washington: U.S. Geological Survey Water-Resources Investigations Report 89-4052, $52 \mathrm{p}$.

Dion, N.P., and Lum, W.E., II, 1977, Municipal, industrial, and irrigation water use in Washington, 1975: U.S. Geological Survey Open-File Report 77-308, 34 p.

Dion, N.P., Olsen, T.D., and Payne, K.L., 1988, Preliminary evaluation of the ground-water resources of Bainbridge Island, Kitsap County, Washington: U.S. Geological Survey Water-Resources Investigations Report 87-4237, $82 \mathrm{p}$.

Dion, N.P., and Sumioka, S.S., 1984, Seawater intrusion into coastal aquifers in Washington, 1978: Washington Department of Ecology Water-Supply Bulletin 56, 13 p.

Dion, N.P., Sumioka, S.S., and Winter, T.C., 1983, General hydrology and external sources of nutrients affecting Pine Lake, King County, Washington: U.S. Geological Survey Water-Resources Investigations Report 83-4057, 29 p.

Drost, B.W., 1979a, Progress report on water resources of the Tulalip Indian Reservation, Washington: U.S. Geological Survey WaterResources Investigations Report 78-31, 39 p.

1979b, Water resources of the Swinomish Indian Reservation, Washington: U.S. Geological Survey Water-Resources Investigations Report 79-12, 83 p.

- 1982, Water resources of the Gig Harbor Peninsula and adjacent areas, Washington: U.S. Geological Survey Water-Resources Investigations Report 81-21, 148 p.

1983a, Impact of changes in land use on the ground-water system in the Sequim-Dungeness Peninsula, Clallam County, Washington: U.S. Geological Survey Water-Resources Investigations Report 83-4094, $61 \mathrm{p}$.

-1983b, Water resources of the Tulalip Indian Reservation, Washington: U.S. Geological Survey Water-Resources Investigations Report 82-648, 153 p.

1985, Appraisal of ground-water conditions and potential for seawater intrusion at Taholah, Quinault Indian Reservation, Washington: U.S. Geological Survey Water-Resources Investigations Report 84-4361, 26 p.

Easterbrook, D.J., 1968, Pleistocene stratigraphy of Island County, Washington: Washington Department of Water Resources Water-Supply Bulletin 25, pt. 1, 34 p., 4 pls.

Easterbrook, D.J., Crandell, D.R., and Leopold, E.B., 1967, Pre-Olympia stratigraphy and chronology in the Central Puget Lowland,
Washington: Geological Society of America Bulletin, v. 78, p. 1320.

Ebbert, J.C., Bortleson, G.C., Fuste, L.A., and Prych, E.A., 1987, Water quality in the lower Puyallup River valley and adjacent uplands, Pierce County, Washington: U.S. Geological Survey WaterResources Investigations Report 86-4154, 199 p.

Eddy, P.A., 1975, Quaternary geology and ground-water resources of San Juan County, Washington, in Russell, R.H., ed., Geology and water resources of the San Juan Islands, San Juan County, Washington: Washington Department of Ecology Water-Supply Bulletin 46, p. 21-39, 3 pls.

Embrey, S.S., 1987, The relation of streamflow to habitat for anadromous fish in the Stillaguamish River basin, Washington: U.S. Geological Survey Water-Resources Investigations Report 864326, 115 p.

1991, Available habitat for salmon and steelhead trout in the lower Puyallup, White and Carbon Rivers in western Washington: U.S. Geological Survey Water-Resources Investigations Report 89-4125, 62 p.

Engebretson, D.C., Cox, A., and Gordon, R.C., 1985, Relative motions between oceanic and continental plates in the Pacific Basin: Geological Society of America Special Paper 206, 59 p.

Environment Canada, n.d., Canadian climate normals, 1951-1980, temperature and precipitation, British Columbia: Atmosphere Environment Service, Canadian Climate Program, UDC:551.582(711), $268 \mathrm{p}$.

Foxworthy, B.L., 1979a, Summary appraisals for the Nation's groundwater resources-Pacific Northwest region: U.S. Geological Survey Open-File Report, Basic-Data Contribution 1, 1 pl.

1979b, Summary of the Nation's ground-water resources-Pacific Northwest Region: U.S. Geological Survey Professional Paper 813-S, $39 \mathrm{p}$.

Freeze, R.A., and Cherry, J.A., 1979, Ground water: Englewood Cliffs, New Jersey, Prentice-Hall, 604 p.

Galster, R.W., and Coombs, H.A., 1989, Cascade ice border dams-geologic setting, in Engineering geology in Washington: Washington Division of Geology and Earth Sciences Bulletin 78, v. 1, p. 203-208.

Gannett, M.G., and Caldwell, R.R., in press, Geological framework of the Willamette Lowland aquifer system, Oregon and Washington: U.S. Geological Survey Professional Paper 1424-A.

Garling, M.E., Molenaar, Dee, and others, 1965, Water resources and geology of the Kitsap Peninsula and certain adjacent islands: Washington Division of Water Resources, Water-Supply Bulletin $18,309 \mathrm{p}$.

Giambelluca, T.W., and Oki, D.S., 1987, Temporal disaggregation of monthly rainfall data for water balance modeling, in Solomon, S.I., Beran, M., and Hogg, W., eds., The influence of climate change and climatic variability on the hydrologic regime and water resources: Proceedings of the Vancouver symposium, August 1987, International Association of Hydrological Sciences Publication No. 168, p. 255-267.

Gladwell, J.S., 1970, Runoff generation in western Washington as a function of precipitation and watershed characteristics: Pullman, Washington State University, College of Engineering Research Division Bulletin 319, 341 p.

Gower, H.D., 1978, Tectonic map of the Puget Sound region, Washington, showing locations of faults, principal folds and large-scale Quaternary deformation: U.S. Geological Survey Open-File Report 78-426, 125 p., 1 pl., scale 1:250,000.

Grimstad, Peder, and Carson, R.J., 1981, Geology and ground-water resources of eastern Jefferson County, Washington: Washington Department of Ecology Water-Supply Bulletin 54, 125 p. 
Grisak, G.E., and Cherry, J.A., 1975, Hydrogeologic characteristics and response of fractured till and clay confining a shallow aquifer: Canadian Geotechnical Journal, v. 12, p. 23-43.

Grisak, G.E., Cherry, J.A., Vonhof, J.A., and Bleumle, J.P., 1976, Hydrogeologic and hydrochemical properties of fractured till in the Interior Plains Region, in Legget, R.F., ed., Glacial till: Royal Society of Canada Special Publication No. 12, p. 304-335.

Gutentag, E.D., Heimes, F.J., Krothe, N.C., Luckey, R.R., and Weeks, J.B., 1984, Geohydrology of the High Plains aquifer in parts of Colorado, Kansas, Nebraska, New Mexico, Oklahoma, South Dakota, Texas, and Wyoming: U.S. Geological Survey Professional Paper 1400-B, $63 \mathrm{p}$.

Hall, J.B., and Othberg, K.L., 1974, Thickness of unconsolidated sediments, Puget lowland, Washington: Washington Department of Natural Resources Geologic Map GM-12, 3 p., 1 pl., scale 1:250,000.

Halstead, E.C., 1986, Ground water supply-Fraser lowland, British Columbia: Environment Canada, National Hydrology Research Institute Paper No. 26, IWD Scientific Series No. 145, 80 p.

Hansen, A.J., Jr., 1993, Modifications to the modular three-dimensional, finite-difference, ground-water flow model used for the Columbia Plateau Regional Aquifer-System Analysis, Washington, Oregon, and Idaho: U.S. Geological Survey Open-File Report 91-532, 162 p.

Hansen, A.J., Jr., and Bolke, E.L., 1980, Ground-water availability on the Kitsap Peninsula, Washington: U.S. Geological Survey Water-Resources Investigations Open-File Report 80-1186, 65 p.

Hansen, H.P., and Mackin, J.H., 1949, A pre-Wisconsin forest succession in the Puget lowland, Washington: American Journal of Science, v. 247, p. 833-855.

Hart Crowser and Associates, Inc., 1984, Final report, hydrogeologic assessment western processing, Kent, Washington: Seattle, Washington, Hart Crowser and Associates, Inc., October 16, 1984, J-1377, 24 p.

-1986, Groundwater resource evaluation of existing and new supply areas, Tacoma, Washington: Seattle, Washington, Hart Crowser and Associates, Inc., April 8, 1988, J-1462-02, unpaginated.

_-1988a, Hydrogeologic report, Judd Hill production well 6C, city of Lacey, Washington: Seattle, Washington, Hart Crowser and Associates, Inc., unpaginated.

- 1988b, Hydrogeologic report, Pleasant Glade test well, city of Lacey, Wash.: Seattle, Washington, Hart Crowser and Associates, Inc., unpaginated.

-1989a, Hydrogeologic report, Hawks Prairie production well, city of Lacey, Washington: Seattle, Washington, Hart Crowser and Associates, Inc., unpaginated.

1989b, Hydrogeologic report, Long Lake test well, city of Lacey, Washington: Seattle, Washington, Hart Crowser and Associates, Inc., unpaginated.

Haushild, W.L., and LaFrance, D.E., 1978, Low-flow characteristics of streams on the Olympic Peninsula, Washington: U.S. Geological Survey Open-File Report 77-812, 25 p.

Hidaka, F.T., 1973, Low-flow characteristics of streams in the Puget Sound region, Washington: U.S. Geological Survey Open-File Report, $55 \mathrm{p}$.

Higgins, G.T., and Hill, G.W., 1973, Analyses and summary of temperatures of streams in Washington prior to 1968: Washington State Department of Ecology, Miscellaneous Report No. 73-003, 139 p.

Hubbert, M.K., 1940, The theory of ground-water motion: The Journal of Geology, v. 48, no. 8, p. 785-944.

Jones, M.A., 1985, Occurrence of ground water and potential for seawater intrusion, Island County, Washington: U.S. Geological Survey Water-Resources Investigations Report 85-4046, 6 sheets.
-1991, Selected references for the Puget-Willamette Lowland Regional Aquifer-System Analysis, Puget Sound Lowland, Washington: U.S. Geological Survey Open-File Report 90-584, 55 p.

- in press, Geologic framework of the Puget Sound aquifer system, Washington and Canada: U.S. Geological Survey Professional Paper 1424-C.

Keller, C.K., van der Kamp, Garth, and Cherry, J.A., 1989, A multiscale study of the permeability of a thick clayey till: Water Resources Research, v. 25, no. 11, p. 2299-2317.

Kohut, A.P., Sather, S., Kwong, J.C., and Chwojka, F., 1989, Nitrate contamination of the Abbotsford aquifer, British Columbia: Environment Canada, Symposium on Groundwater Contamination, unpaginated.

Kwong, J.C., 1986, Groundwater quality monitoring and assessment program-The occurrence of nitrate-nitrogen in groundwater in the Langley-Abbotsford area: Groundwater section, Water Management Division, British Columbia Ministry of Environment, Memorandum Report, File 0329563-1.

Landes, Henry, 1905, Preliminary report on the underground waters of Washington: U.S. Geological Survey Water-Supply Paper III, $85 \mathrm{p}$.

Liebscher, H., Hii, B., and McNaughton, D., 1992, Nitrates and pesticides in the Abbotsford aquifer, southwestern British Columbia: Vancouver, British Columbia, Environment Canada, Inland Water Directorate, $83 \mathrm{p}$.

Lum, W.E., II, 1984, Availability of ground water from the alluvial aquifer on the Nisqually Indian Reservation, Washington: U.S. Geological Survey Water-Resources Investigations Report 83$4185,42 \mathrm{p}$.

Lum, W.E., II, Alvord, R.C., and Drost, B.W., 1984, Availability of water from the alluvial aquifer in part of the Green River valley, King County, Washington: U.S. Geological Survey WaterResources Investigations Report 83-4178, $40 \mathrm{p}$.

Lum, W.E., II, and Turney, G.L., 1982, Fluoride, nitrate, and dissolved solids concentrations in ground waters of Washington: U.S. Geological Survey Water-Resources Investigations Open-File Report 82-508, 4 pls. 1985, A preliminary evaluation of hydrology and water quality near the Tacoma landfill, Pierce County, Washington: U.S. Geological Survey Water-Resources Investigations Report 84-4351, $35 \mathrm{p}$.

Lum, W.E., II, and Walters, K.L., 1976, Reconnaissance of groundwater resources of the Squaxin Island Indian Reservation, Washington: U.S. Geological Survey Open-File Report 76-382, 49 p.

Marshall, T.J., and Holmes, J.M., 1979, Soil physics: Cambridge, Massachusetts, Cambridge University Press, 345 p.

Mastin, M.C., 1996, Surface-water hydrology and runoff simulation for three basins in Pierce County, Washington: U.S. Geological Survey Water-Resources Investigations Report 95-4068, 148 p.

McDonald, M.G., and Harbaugh, A.W., 1988, A modular three-dimensional finite-difference ground-water flow model: U.S. Geological Survey Techniques of Water Resources Investigations, book 6, chap. A1, 586 p.

Melvin, R.L., deLima, V., and Stone, B.D., 1992, The stratigraphy and hydraulic properties of tills in southern New England: U.S. Geological Survey Open-File Report 91-481, 53 p.

METRO, 1983, Renton effluent transfer system, predesign study, Phase 1 preliminary report, geotechnical: Municipality of Metropolitan Seattle, Contract No. CW-F282, January 7, 1983, v. A-Geotechnical, 81 p.

Miller, R.D., and Pessl, Fred, Jr., 1986, Map showing unconsolidated deposits grouped on the basis of texture, Port Townsend quadrangle, Puget Sound region, Washington: U.S. Geological Survey Miscellaneous Investigations Map I-1198-D, 1 pl., scale $1: 100,000$. 
Molenaar, Dee, Grimstad, Peder, and Walters, K.L., 1980, Principal aquifers and well yields in Washington: Washington Department of Ecology Geohydrologic Monograph 5, 1 pl., scale 1:1,000,000.

Nassar, E.G., 1973, Low-flow characteristics of streams in the Pacific Slope basins and lower Columbia River basin, Washington: U.S. Geological Survey Open-File Report, 68 p.

Newcomb, R.C., Sceva, J.E., and Stromme, Olaf, 1949, Ground-water resources of western Whatcom County, Washington: U.S, Geological Survey Open-File Report 50-7, 134 p.

Noble, J.B., 1990, Proposed revision of nomenclature for the Pleistocene stratigraphy of coastal Pierce County, Washington: Washington Division of Geology and Earth Resources, OpenFile Report 90-4, 54 p.

Noble, J.B., and Wallace, E.F., 1966, Geology and ground-water resources of Thurston County, Washington: Washington Division of Water Resources, Water-Supply Bulletin 10, v. 2, 141 p.

Olmstead, T.L., 1969, Geotechnical aspects and engineering properties of glacial till in the Puget Lowland, Washington, in Proceedings of the 7th Annual Engineering Geology and Soils Engineering Symposium: Moscow, Idaho, p. 223-233.

Pacific Northwest River Basins Commission, 1970, Comprehensive framework study of water and related lands, appendix V, v. 2, water resources: Vancouver, Washington, $1022 \mathrm{p}$.

-1971, Comprehensive framework study of water and related lands, appendix XI, municipal and industrial water supply: Vancouver, Washington, $256 \mathrm{p}$.

Pardee, J.T., 1931, Report on the occurrence of artesian water at the United States Navy Yard, Kitsap County, Washington: U.S. Geological Survey Open-File Report, 10 p.

Pearce, A.J., Gash, J.H.C., and Stewart, J.B., 1980, Rainfall interception in a forest stand estimated from grassland meteorological data: Journal of Hydrology, v. 46, p. 147-163.

Piper, A.M., 1930, Water supply of the United States Penitentiary at McNeil Island, Washington: U.S. Geological Survey Open-File Report, 52 p.

Piper, A.M., and La Rocque, G.A., Jr., 1938, Ground water in the Tacoma area, Washington, progress report no. 1: U.S. Geological Survey Open-File Report, 105 p.

Plummer, L.N., Michel, R.L., Thurman, E.M., and Glynn, P.D., 1993, Environmental tracers for age dating young ground water, in Alley, W.M., ed., Regional ground-water quality: New York, Van Nostrand Reinbold, p. 255-294.

Pollock, D.W., 1989, Documentation of computer programs to compute and display pathlines using results from the U.S. Geological Survey modular three-dimensional finite-difference groundwater flow model: U.S. Geological Survey Open-File Report 89-381, 188 p.

Prych, E.A., and Ebbert, J.C., 1986, Quantity and quality of storm runoff from three urban catchments in Bellevue, Washington: U.S. Geological Survey Water-Resources Investigations Report 864000, 85 p.

Puget Sound Task Force, 1970, Comprehensive study of water and related land resources, Puget Sound and adjacent waters, State of Washington, appendix III, hydrology and natural environment: Vancouver, Washington, Pacific Northwest River Basins Commission, 205 p.

Puget Sound Water Quality Authority, 1992, State of the Sound, 1992 report: Olympia, Washington, Puget Sound Water Quality Authority, unpaginated.

Richardson, Donald, Bingham, J.W., and Madison, R.J., 1968, Water resources of King County, Washington: U.S. Geological Survey Water-Supply Paper 1852, 74 p., 2 pls.
Robinson, J.W., and Piper, A.M., 1942, Water levels in observation wells and stages of certain lakes of the Tacoma area, Washington: U.S. Geological Survey Open-File Report, 277 p.

Sapik, D.B., Bortleson, G.C., Drost, B.W., Jones, M.A., and Prych, E.A., 1988, Ground-water resources and simulation of flow in aquifers containing freshwater and seawater, Island County, Washington: U.S. Geological Survey Water-Resources Investigations Report 87-4182, 67 p, 4 pls.

Seattle Water Department, 1986, Proposal for ground water recharge demonstration program at Highline well field: Seattle, Washington, Seattle Water Department, April 1986, 71 p.

Snavely, P.D., Jr., 1988, Tertiary geologic framework, neotectonics, and petroleum potential of the Oregon-Washington continental margin, in Scholl, D.S., Grantz, A., and Vedder, J.G., eds., Geology and resource potential of the continental margin of western North America and adjacent ocean basins-Beaufort Sea to Baja, California: Circum-Pacific Council for Energy and Mineral Resources Earth Science Series 6, p. 305-335.

Sun, R.J., ed., 1986, Regional Aquifer-System Analysis Program of the U.S. Geological Survey - summary of projects, 1978-84: U.S. Geological Survey Circular 1002, $264 \mathrm{p}$.

Swift, C.H., III, 1976, Estimation of stream discharges preferred by steelhead trout for spawning and rearing in western Washington: U.S. Geological Survey Open-File Report 75-155, 50 p. 1979, Preferred stream discharges for salmon spawning and rearing in Washington: U.S. Geological Survey Open-File Report 77-422, $51 \mathrm{p}$.

Theis, C.V., 1963, Estimating the transmissibility of a water-table aquifer from the specific capacity of a well, in Bentall, Ray, compiler, Methods of determining permeability, transmissibility, and drawdown: U.S. Geological Survey Water-Supply Paper 1536-I, p. 332-336.

Thornthwaite, C.W., 1948, An approach toward a rational classification of climate: Geographical Review, v. 38, p. 55-94.

Thornthwaite, C.W., Mather, J.R., and Carter, D.B., 1957, Instructions and tables for computing potential evapotranspiration and the water balance: Centeron, New Jersey, Drexel Institute of Technology, Laboratory of Climatology, Publications in Climatology, v. 10, no. 3, unpaginated.

Thorson, R.M., 1980, Ice-sheet glaciation of the Puget lowland, Washington, during the Vashon Stade (late Pleistocene): Quaternary Research, v. 13, no. 3, p. 303-321.

1989, Glacio-isotactic response of the Puget Sound area, Washington: Geological Society of America Bulletin, v. 101, p. 11631174.

Tracy, J.V., and Dion, N.P., 1976, Evaluation of ground-water contamination from cleaning explosive projectile casings at the Bangor Annex, Kitsap County, Washington, phase II: U.S. Geological Survey Water-Resources Investigations Open-File Report 62-75, $44 \mathrm{p}$.

Turney, G.L., 1986, Quality of ground water in the Puget Sound Region, Washington, 1981: U.S. Geological Survey WaterResources Investigations Report 84-4258, 170 p., 2 pls.

Turney, G.L., and Goerlitz, D.F., 1988, Ground-water contamination at an inactive coal and oil gasification plant site, Gas Works Park, Seattle, Washington: U.S. Geological Survey Water-Resources Investigations Report 88-4224, 31 p.

Turney, G.L., Kahle, S.C., and Dion, N.P., 1995, Geohydrology and ground-water quality of East King County, Washington: U.S. Geological Survey Water-Resources Investigations Report 94-4082, 123 p., 5 pls.

URS Consultants, Inc., 1992, Operable Unit 3, Draft Remedial/Feasibility Study-Remedial investigation report: Silverdale, Washington, U.S. Navy CLEAN Program, Northwest Area, Bangor Naval Submarine Base, I and II, unpaginated. 
U.S. Department of Agriculture, 1970, Irrigation water requirements: U.S. Soil Conservation Service Engineering Division, Technical Release No. 21, 79 p.

U.S. Environmental Protection Agency, 1984, Hydrologic simulation program-FORTRAN (HSPF)-users manual for release 8.0: Environmental Research, EPA-600/3-84-066, 767 p.

U.S. Geological Survey, 1976, Hydrologic unit map-1974 State of Washington: U.S. Geological Survey Hydrologic Unit Map-1974, 1 sheet, scale 1:500,000.

1990, Land use and land cover digital data from 1:250,000- and 1:100,000-scale maps, data users guide: Reston, Virginia, U.S. Geological Survey, National Mapping Program, Technical Construction, Data Users Guide 4, 33 p.

U.S. Weather Bureau, 1965, Mean annual precipitation, 1930-1957, State of Washington: Portland, Oregon, Soil Conservation Service, $1 \mathrm{pl}$.

Vaccaro, J.J., 1992, Plan of study for the Puget-Willamette Lowland Regional Aquifer-System Analysis, western Washington and western Oregon: U.S. Geological Survey Water-Resources Investigations Report 92-4189, 41 p.

- in press, Summary of the Puget-Willamette Lowland Regional Aquifer-System Analysis, Washington, Oregon, and British Columbia: U.S. Geological Survey Open-File Report 96-353.

VanDenburgh, A.S., and Santos, J.F., 1965, Ground water in Washington-Its chemical and physical quality: Washington State Pollution Control Commission Water-Supply Bulletin 24, $93 \mathrm{p}$.

Vanderwal, K.S., 1985, Compositional and textural variations in the Vashon till and underlying drifts in the northern and central Puget lowland, Washington: Seattle, University of Washington, unpublished M.S. thesis, $110 \mathrm{p}$.

Walters, K.L., 1971, Reconnaissance of sea-water intrusion along coastal Washington, 1966-68: Washington Department of Ecology, Water-Supply Bulletin 32, 208 p.

Walters, K.L., Haushild, W.L., and Nelson, L.M., 1979, Water resources of the lower Elwha Indian Reservation, Washington: U.S. Geological Survey Water-Resources Investigations Report 79-82, $55 \mathrm{p}$.

Walters, K.L., and Kimmel, G.E., 1968, Ground-water occurrence and stratigraphy of unconsolidated deposits, central Pierce County, Washington: Washington Department of Water Resources Water-Supply Bulletin 22, 428 p., 3 pl.
Washington Department of Ecology, 1978, Coastal zone atlas of Washington, v. 12, Clallam County: Washington Department of Ecology, DOE 77-21-12, 10 p.

Weaver, C.E., 1937, Tertiary stratigraphy of western Washington and northwestern Oregon: Seattle, University of Washington Publications in Geology, v. 4, 266 p.

Whiteman, K.J., Molenaar, Dee, Bortleson, G.C., and Jacoby, J.M., 1983, Occurrence, quality, and use of ground water in Orcas, San Juan, Lopez, and Shaw Islands, San Juan County, Washington: U.S. Geological Survey Water-Resources Investigations Report 83-4019, 12 sheets, scale 1:62,500.

Williams, J.R., 1984, Principal surface-water inflow to Puget Sound, Washington: U.S. Geological Survey Water-Resources Investigations Report 84-4090, 6 sheets, scale 1:500,000.

- 1987, Estimates of streamflow characteristics for selected small streams, Baker River basin, Washington: U.S. Geological Survey Water-Resources Investigations Report 87-4006, 28 p.

Williams, J.R., Pearson, H.E., and Wilson, J.D., 1985a, Streamflow statistics and drainage-basin characteristics for the Puget Sound region, volume I, Western and southern Puget Sound: U.S. Geological Survey Open-File Report 84-144-A, 330 p., 1 pl. 1985b, Streamflow statistics and drainage-basin characteristics for the Puget Sound region, volume II, Eastern Puget Sound from Seattle to the Canadian border: U.S. Geological Survey Open-File Report 84-144-B, 420 p., 1 pl.

Williams, R.W., Laramie, R.M., and Ames, J.J., 1975, A catalog of Washington streams and salmon utilization, volume 1, Puget Sound region: Olympia, Washington State Department of Fisheries, 19 chap.

Willis, Baily, 1898, Drift phenomena of Puget Sound: Bulletin of the Geological Society of America, v. 9, p. 111-162, pls. 6-10.

Woodward, D.G., Gannett, M.G., and Vaccaro, J.J., in press, Hydrogeologic framework of the Willamette Lowland aquifer system, Oregon and Washington: U.S. Geological Survey Professional Paper 1424-B.

Wood ward, D.G., Packard, F.A., Dion, N.P., and Sumioka, S.S., 1995 Occurrence and quality of ground water in southwestern King County, Washington: U.S. Geological Survey Water-Resources Investigations Report 92-4098, 69 p., 4 pls.

Yount, J.C., Dembroff, G.R., and Barats, G.M., 1985, Map showing depth to bedrock in Seattle $30^{\prime}$ by $60^{\prime}$ quadrangle, Washington: U.S. Geological Survey Miscellaneous Field Investigations Map MF-1692, 12 p., 1 pl., scale 1:100,000. 